\title{
A PP4 foszfatáz kölcsönható partnereinek azonosítása és szubsztrátum-felismerő mechanizmusának feltárása
}

\author{
Ph.D. értekezés \\ Szerző: Kármán Zoltán \\ Témavezető: Dr. Lipinszki Zoltán \\ Szegedi Biológiai Kutatóközpont \\ Biokémiai Intézet
}

Biológia Doktori Iskola

Szegedi Tudományegyetem

Természettudományi és Informatikai Kar

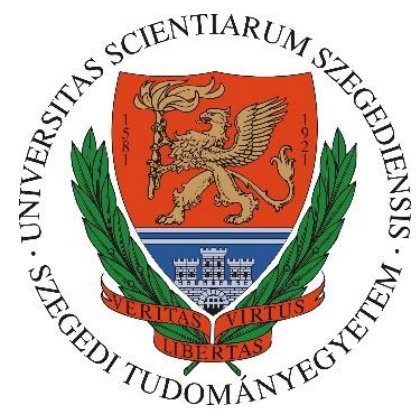

Szeged

2020 


\section{TARTALOMJEGYZÉK}

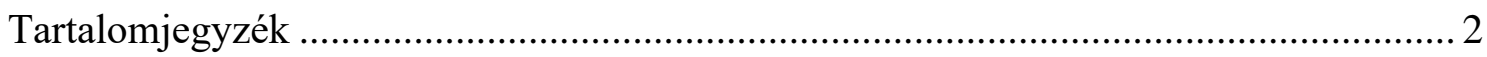

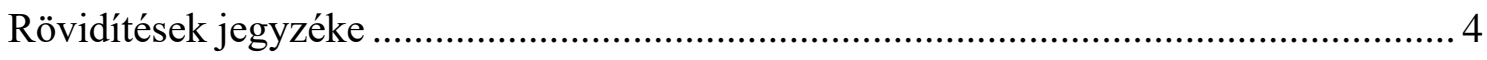

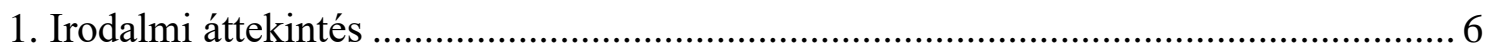

1.1. A reverzibilis fehérje foszforiláció szerepe ….................................................. 6

1.2. A fehérje foszfatázok csoportosítása ........................................................... 8

1.3. A PP4 foszfatáz alegységei, szabályozása és evolúciós konzerváltsága ............. 10

1.4. A PP4 foszfatáz szabályozó szerepe különböző folyamatokban ........................ 13

1.4.1. Sejtciklus és sejtosztódás ....................................................... 13

1.4.2. Sejt-differenciálódás és túlélés................................................. 16

1.4.3. DNS hibajavítás .................................................................... 18

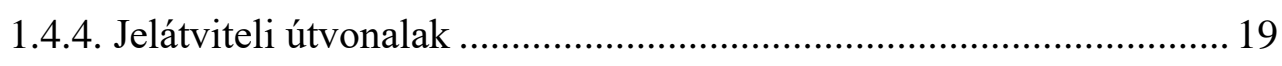

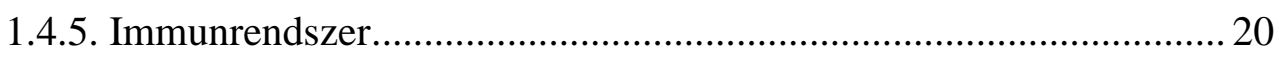

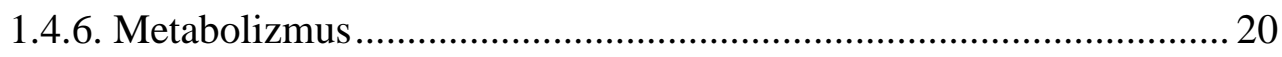

1.5. A fehérje foszfatázok szubsztrátum-felismerése ......................................... 21

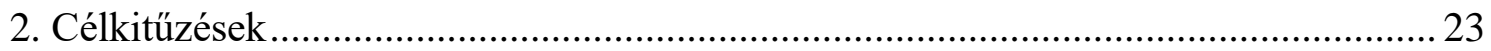

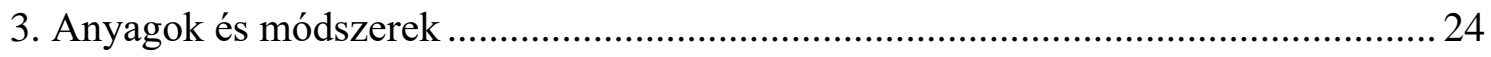

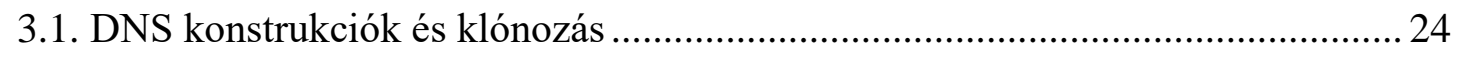

3.2. Drosophila törzsek fenntartása és embriók gyüjtése ….................................... 26

3.3. Stabilan transzfektált Drosophila D.Mel-2 sejtvonalak létrehozása.................... 26

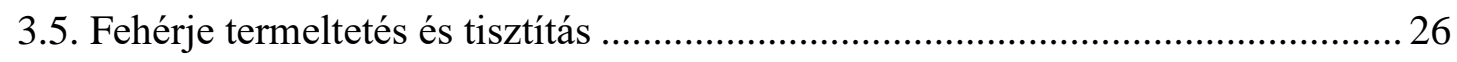

3.4. Affinitás tisztításhoz kötött tömegspektrometriai azonosítás (AP-MS) .............. 27

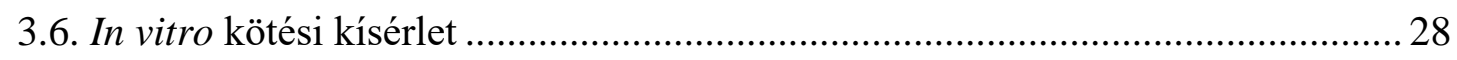

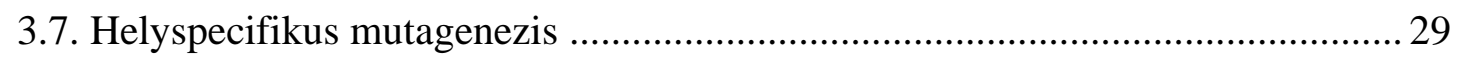

3.8. Ko-immunprecipitáció (Co-IP) D.Mel-2 sejtekböl........................................... 29

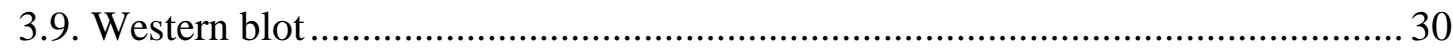

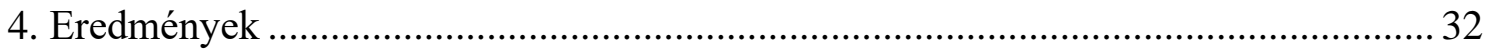


4.2. A Flfl valós fizikai interakciós partnereinek meghatározása in vitro kötési

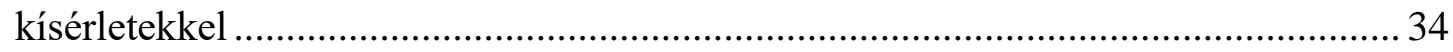

4.3. Az interakciós felületek térképezése............................................................... 37

4.4. A konzervált EVH1 felismerési motívum azonosítása és a kötőhelyek

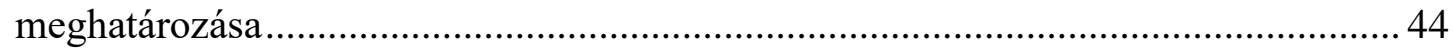

4.5. A Flfl 70. leucinjának szerepe a szubsztrátum kötésben .................................. 49

4.6. Az Smk-1 domén lehetséges szerepe a PP4 szubsztrátum kötésében ................. 51

4.7. A PP4/Flfl és CENP-C szabályozó szerepe a Barrier-to-autointegration factor

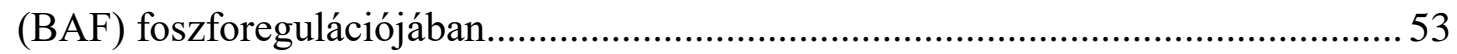

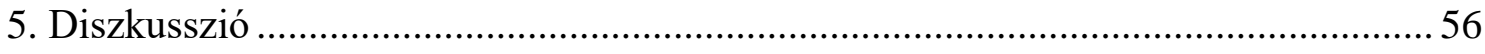

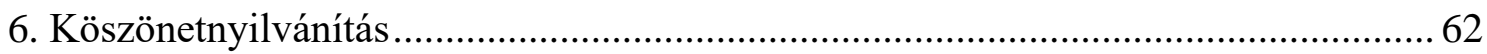

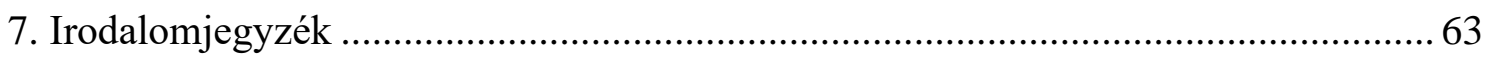

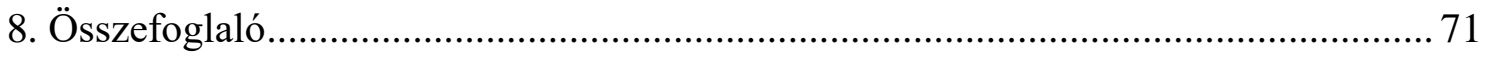

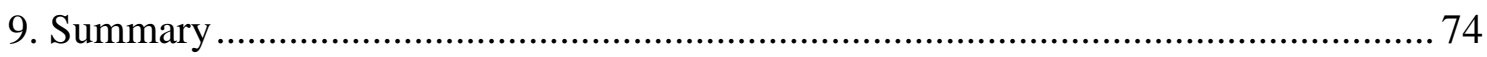

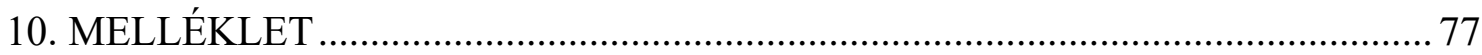




\section{RÖVIDÍTÉSEK JEGYZÉKE}

$\begin{array}{ll}\text { A } & \text { alanin } \\ \text { AP } & \text { affinitás tisztítás } \\ \text { ATP } & \text { adenozin trifoszfát } \\ \text { BAF } & \text { barrier-to-autointegration factor } \\ \text { BSA } & \text { borjú szérum albumin } \\ \text { CENP-C } & \text { Centromérikus fehérje C } \\ \text { Co-IP } & \text { ko-immunprecipitáció } \\ \text { DNS } & \text { dezoxiribonukleinsav } \\ \text { DTT } & \text { ditiotreitol } \\ \text { EDTA } & \text { etilén-diamin-tetraecetsav } \\ \text { EGTA } & \text { etilén-glikol tetraecetsav } \\ \text { FBD } & \text { A CENP-C fehérje Falafel-kötő doménje } \\ \text { F } & \text { fenilalanin } \\ \text { FIM } & \text { A CENP-C fehérje Falafel-interakciós motívuma } \\ \text { Flfl } & \text { Falafel, a Drosophila melanogaster PP4R3 alegysége } \\ \text { GFP } & \text { zöld fluoreszcens fehérje } \\ \text { GST } & \text { glutation S-transzferáz } \\ \text { HAD } & \text { halosav dehalogenáz } \\ \text { HRP } & \text { torma peroxidáz } \\ \text { IPTG } & \text { 1-tio-b-D-galaktopiranozid } \\ \text { IVTT } & \text { kapcsolt in vitro transzkripció/transzláció } \\ \text { JNK } & \text { c-Jun N-terminális kináz } \\ \text { kDa } & \text { kilodalton } \\ \text { LMW } & \text { kis molekulasúlyú foszfatáz } \\ \text { M } & \text { metionin } \\ \text { MS } & \text { tömegspektrometria } \\ \text { NF- } \text { PB } & \text { nukleáris faktor kappa B } \\ \text { P } & \text { poliakrilamid gélelektroforézis } \\ \text { PAGE } & \text { polimeráz láncreakció } \\ \text { PCRhibítor koktél } \\ \text { PI-szulfonil fluorid }\end{array}$




$\begin{array}{ll}\text { PP4 } & \text { protein foszfatáz } 4 \\ \text { PP4IP } & \text { protein foszfatáz } 4 \text { inhibitor fehérje } \\ \text { PPM } & \text { fémion-függő fehérje foszfatáz } \\ \text { PPP } & \text { foszfoprotein foszfatáz } \\ \text { Psy2 } & \text { platinum sensitivity } 2 \\ \text { PTP } & \text { protein tirozin foszfatáz } \\ \text { PVDF } & \text { polivinilidén-fluorid } \\ \text { S/Ser } & \text { szerin } \\ \text { SDS } & \text { nátrium-dodecil-szulfát } \\ \text { SMEK } & \text { supressor of MEK-1 } \\ \text { SLiM } & \text { rövid lineáris motívum } \\ \text { T/Thr } & \text { treonin } \\ \text { TNF } \alpha & \text { tumor nekrózis faktor alfa } \\ \text { Y/Tyr } & \text { tirozin }\end{array}$




\section{IRODALMI ÁTTEKINTÉS}

\subsection{A reverzibilis fehérje foszforiláció szerepe}

A fehérje foszforiláció a leggyakoribb reverzibilis kémiai módosítás az eukarióta sejtekben [1]. A foszforilációs és defoszforilációs események egyensúlya nélkülözhetetlen a sejtfiziológia számos vonatkozásában, az egyensúly felborulása betegségek kialakulásához vezethet [2, 3]. A fehérjék foszforilációs állapotát két létfontosságú, egymással ellentétes hatású enzimcsalád katalizálja egy foszfát csoport hozzáadásával (fehérje kinázok), illetve eltávolításával (fehérje foszfatázok) a szerin (Ser), treonin (Thr) és tirozin (Tyr) aminosavak hidroxil csoportjáról (1. ábra).

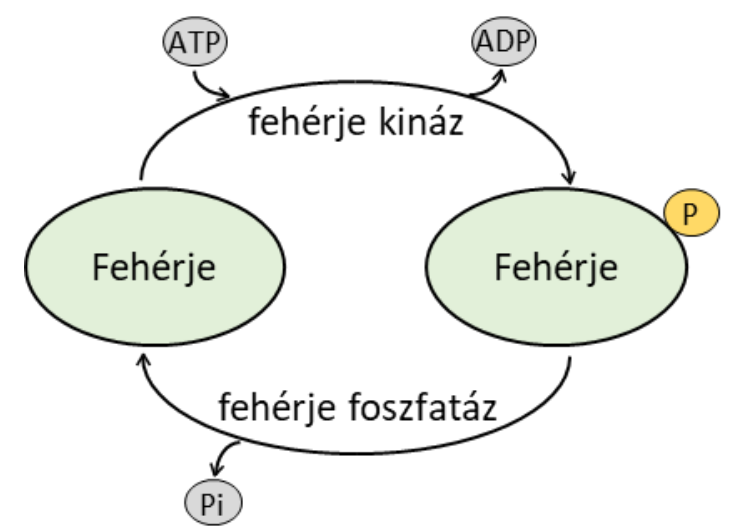

1. ábra. A fehérje foszforiláció és defoszforiláció. A reverzibilis fehérje foszforilációt két, egymással antagonisztikus hatású enzimcsalád katalizálja. A fehérje kinázok egy ATP felhasználásával a fehérjék Ser, Thr és Tyr aminosavainak hidroxil csoportjához képesek egy foszfát csoportot kapcsolni, amit a fehérje foszfatázok képesek eltávolítani.

A fehérjék számos helyen foszforilálódhatnak a sejtben található kinázok révén, ami lehetővé teszi fiziológiás jelek széles spektrumának integrálását, mely különböző funkcionális válaszokat eredményezhet [4]. Míg a tirozin foszforiláció csupán az összes foszforilációs esemény kevesebb, mint 2\%-át teszi ki az állati sejtekben, a fennmaradó rész a szerin és treonin oldalláncokat érinti. Ez egybefügg azzal a ténnyel, miszerint a humán genomban kódolt több mint 500 fehérje kináz 80\%-a Ser és Thr foszforilációt katalizál [5]. Egy fehérje foszforilációs állapotának változása számos következménnyel járhat: meghatározhatja annak fizikokémiai tulajdonságait, interakciós partnereit, aktivitását, stabilitását vagy sejten belüli elhelyezkedését [6-9]. A fehérje foszforeguláció igen dinamikus, néhány esetben a módosítás csupán pár másodpercig marad fenn [10]. Ez energetikai szempontból ATP pazarlásnak tünhet, de a gyakorlatban mégis előnyös a 
sejt számára. Ily módon megnő a sejt érzékenysége a környezeti ingerekre és lehetőséget biztosít a jelátviteli folyamatok idő-és térbeli finomhangolására. Míg a fehérje kinázok a legintenzívebben kutatott és legjobban ismert enzimek közé tartoznak, addig a fehérje foszfatázokról sokkal kisebb tudásanyaggal rendelkezünk; funkciójuk, specificitásuk, összetételük és szabályozásuk pontos molekuláris részletei még alig feltártak.

A fehérje foszfatázok két legnagyobb családjába (PPP és PPM) körülbelül 40 gén tartozik, ami az emlös genomban kódolt több mint 400 Ser/Thr kináz génhez képest elenyészőnek tünhet. Ez alapján arra a téves következtetésre juthatunk, hogy a fehérje foszfatázok szubsztrátum spektruma sokkal szélesebb és kevésbé specifikus, mint a fehérje kinázoké. De ha ez nem így van, akkor hogyan tudja kisszámú foszfatáz gén ellensúlyozni a temérdek kináz aktivitását, megtartva szubsztrátum-specificitásukat? A kinázokkal ellentétben a foszfatázok nagyon ritkán fordulnak elő önálló katalitikus alegységek formájában, helyette többféle regulátor alegységgel, multienzim komplexeket (holoenzimeket) alkotnak. Ezekben a komplexekben a katalitikus alegységek egy vagy több regulátor alegységgel kapcsolódnak össze, amik meghatározzák a holoenzim katalitikus aktivitását, sejten belüli lokalizációját és szubsztrátum specificitását. Így az eukarióta sejtekben a foszfatáz komplexek száma közel egyenlő a fehérje kinázok számával [11-13].

A kinázok és foszfatázok ilyen egyenlősége azonban még nem azt jelenti, hogy csupán egyetlen kináz/foszfatáz páros szabályoz egy fehérjét vagy egy adott foszforilációs helyet. A humán foszfoproteómban 2014-re már több mint 38000 egyéni foszforilációs helyet azonosítottak [14]. Ez a szám folyamatosan növekszik azóta is, hiszen a különböző fiziológiás körülmények és sejttípusok vizsgálatával egyre több foszforilációs helyet azonosítanak, ami azt jelenti, hogy minden kináz és foszfatáz számos fehérje foszforegulációjáért felelős. A fehérjéken az esetek nagy részében több foszforilációs hely is található, ami a fehérje-funkció még összetettebb és precízebb szabályozását teszi lehetővé.

A jelátviteli utakban a negatív regulátorokra, mint a foszforiláció esetében a foszfatázokra, sokáig csak, mint a jel megszüntetőire (háztartási gének) tekintettek, tévesen [15]. Ma már tudjuk, hogy a defoszforiláció nem csupán egy kikapcsoló mechanizmus, sokkal inkább a stimulusra adott válasz gyorsaságának és hosszának meghatározója, míg a kinázok a válasz erősségének meghatározásában játszanak jelentős szerepet [16]. A kinázok és foszfatázok közötti kommunikáció lehetővé teszi az olyan 
összetett folyamatok, mint például a számtartó osztódás (mitózis) eseményeinek hibátlan lebonyolítását [17].

\subsection{A fehérje foszfatázok csoportosítása}

A fehérje foszfatázoknak két fó csoportja ismert (2. ábra): Tyr foszfatázokra, mely magába foglalja a foszfotirozin foszfatázokat (PTP), a kettős specificitású foszfatázokat (DSP) és a kis molekulasúlyú foszfatázokat (LMW), illetve a Ser/Thr foszfatázokra. A Ser/Thr foszfatázok három családját különíthetjük el az elsődleges szerkezetük és a katalitikus mechanizmusuk alapján. Ezek a $\mathrm{Mg}^{2+} / \mathrm{Mn}^{2+}$ függő fehérje foszfatázok (PPM), a foszfoprotein foszfatázok (PPP), valamint a halosav dehalogenázok (HAD) [18].

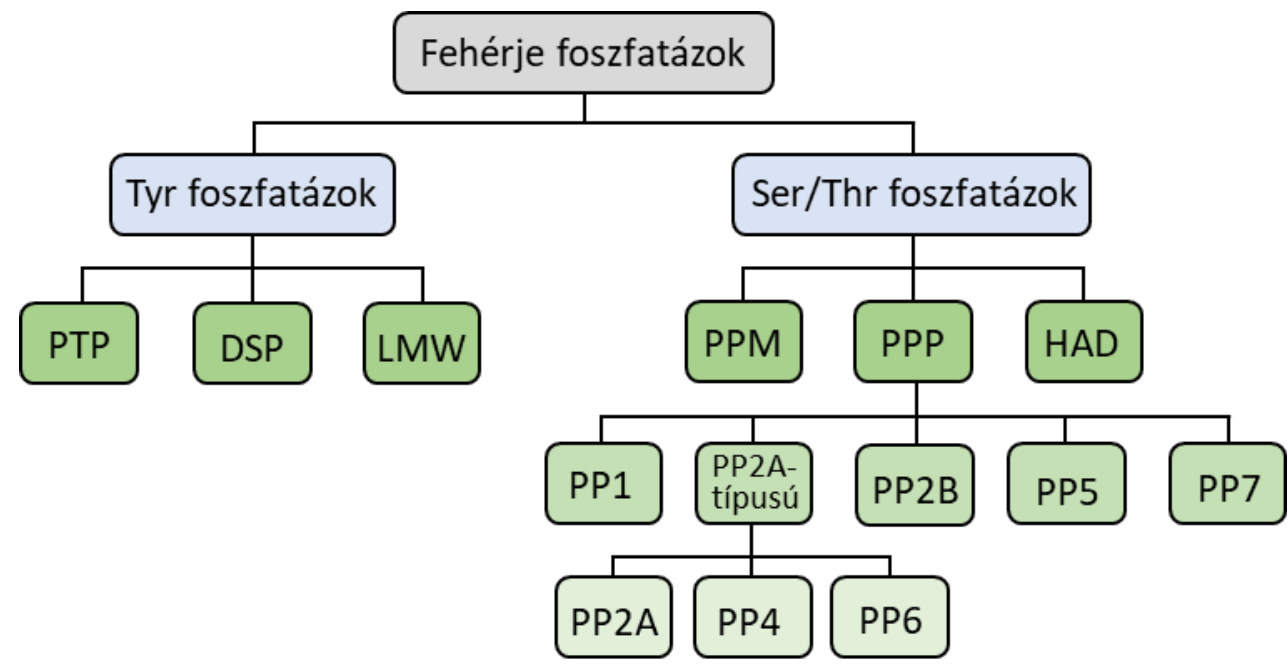

2. ábra. A fehérje foszfatázok csoportosítása. A fehérje foszfatázok két fó csoportja a Tyr foszfatázok és a Ser/Thr foszfatázok. A Tyr foszfatázok családja magába foglalja a foszfotirozin foszfatázokat (PTP), a kettős specifitású foszfatázokat (DSP) és a kis molekulasúlyú foszfatázokat (LMW). A Ser/Thr foszfatázok csoportjába a $\mathrm{Mg}^{2+} / \mathrm{Mn}^{2+}$ függő fehérje foszfatázok (PPM), a foszfoprotein foszfatázok (PPP) és a halosav dehalogenázok (HAD) tartoznak. A PPP-k a foszfatázok legnépesebb családja, melyhez hét foszfatáz tartozik, név szerint a PP1, PP2A, PP2B (más néven PP3 vagy calcineurin), PP4, PP5, PP6 és PP7. Ezen foszfatázok közül a PP2A, PP4 és PP6 egy külön alcsaládot alkotnak katalitikus alegységeik nagyfokú homológiája miatt.

A Ser/Thr PPM foszfatázok katalitikus alegységének közös jellemzője két bivalens fémion $\left(\mathrm{Mg}^{2+}\right.$ vagy $\left.\mathrm{Mn}^{2+}\right)$ jelenléte. Katalitikus mechanizmusuk a PPP foszfatázokhoz hasonló [19]. A PPM-ek föképp növényekben jelentősek, ahol különböző környezeti stresszre adott válaszokban és a hormonális jelátviteli utakban játszanak kiemelkedő szerepet az abszcizinsav receptor alegységeként [20]. A PPM családnak bár nem olyan jelentős, de fontos szerepe van az emlősök stressz-jelátvitelének és növekedésének szabályozásában is [21]. 
A PPP foszfatázok az evolúciósan legerősebben konzervált enzimek közé tartoznak. Ebbe a családba a katalitikus alegységek alapján hét különböző foszfatáz (katalitikus alegység) tartozik: PP1, PP2A, PP2B (más néven PP3 vagy kalcineurin), PP4, PP5, PP6 és PP7. A PPP foszfatázok a Ser/Thr foszfatázok legnépesebb családját képezik, és a sejtek csaknem minden folyamatában fontos szabályozó szerepet töltenek be [22, 23]. A PPP foszfatázok közül a két legismertebb és legjelentősebb a PP1 és a PP2A, melyek egyben a legnagyobb koncentrációban előforduló foszfatázok a sejtben. A heterodimerként funkcionáló PP1 esetében több mint 200 különböző regulátor alegységet azonosítottak eddig, melyek szabályozzák a négyféle PP1c (c - katalitikus alegység) aktivitását és szubsztrátum specificitását [22]. A PP2A típusú foszfatázok leggyakrabban három alegységes, heterotrimer fehérje komplexek formájában aktívak, az esetükben több tucatra tehető az eddig azonosított regulátor alegységek száma. Az emlős PP2A-típusú foszfatázok, vagyis a PP2A, PP4 és a PP6 egymással sokkal közelebbi rokonságban állnak az aminosav szekvencia szintjén, mint a család többi tagjával. Ezeknek a foszfatázoknak a génjei a magasabb rendü gerincesek mellett megtalálhatóak alacsonyabbrendü eukariótákban is, úgy, mint a Saccharomyces cerevisiae (PPH21, PPH3 és SIT4), a Schizosaccharomyces pombe (pp2, pph3 és ppe1), a Caenorhabditis elegans (LET-92, PPH-4.1 és PPH-6) és a Drosophila melanogaster (mts, Pp4-19C és PpV). Ráadásul a különböző fajokból származó katalitikus és regulátor alegységek (egy adott foszfatáz esetében) képesek egymással is összekapcsolódni, illetve némely esetben a mutáns háttéren kialakult fenotípus változásokat menekíteni, azaz egymás funkcióit komplementálni [24, 25]. A pontos funkciók és szabályozásban betöltött szerepek fajonként kisebb-nagyobb eltéréseket mutatnak, ráadásul a szekvencia és holoenzim összetétel konzerváltságának ellenére eltérő szubsztrátumokat defoszforilálhatnak [23].

A halosav dehidrogenázok a Ser/Thr foszfatázok harmadik családja, viszonylag kis enzimatikus aktivitással [26]. A PPP és PPM foszfatázokkal ellentétben a HAD-ok nem metalloenzimek. Az alacsony aktivitásuk szűk szubsztrátum specificitással párosul, kizárólag az RNS polimeráz II C-terminálisán lévő foszfo-szerineket képesek defoszforilálni [27]. 


\subsection{A PP4 foszfatáz alegységei, szabályozása és evolúciós konzerváltsága}

A PP4 két vagy három alegységből álló holoenzim komplexként müködhet. A PP4 alegységeken kívül ismert még néhány olyan regulátor fehérje és molekula, amely kapcsolódhat a katalitikus alegységhez, ezzel módosítva annak aktivitását. A PP4 katalitikus alegysége (PP4c) heterodimer komplexet alkothat a PP4R1 vagy PP4R4 alegységekkel (emlősökben), illetve heterotrimer komplexeket a PP4R2 és PP4R3A (SMEK1 emlősökben), illetve a PP4R2 és PP4R3B (SMEK2 emlősökben) alegységekkel [28-35]. A PP4 közelebbi rokonságban áll a PP2A-val, mint a PP1-el, előbbivel 65\%-os elsődleges szekvencia azonosságot mutat [36]. A 35 kDa nagyságú katalitikus alegység számos szövetben kifejeződik, elsőként sertés heréből sikerült izolálni, ugyanis az agy mellett a tesztiszekben az egyik legnagyobb az mRNS és fehérje szintje [37-39]. A katalitikus alegység aktivitását számos kis molekula képes gátolni alacsony koncentrációban, mint amilyen az okadainsav, mikrocisztin, kalikulin-A, tautomicin és kantaridin [36, 38, 40]. A PP4c/PP4R1 komplexet elsőként Kloeker és Wadzinski azonosította [35], amely heterodimer komplex a két alegységét sztöchiometrikus arányban tartalmazza. A PP4R1 nagyfokú hasonlóságot mutat a PP2A A-típusú (állvány) alegységével, ami arra enged következtetni, hogy az R1 alegység egy szerkezeti vázként szolgál a katalitikus alegység számára. Maga a PP4R1 13 ismétlődő régióból áll (HEATrepeat) egy hosszabb megszakítással a 6. és 7. ismétlődések között [35]. Hastie és munkatársai azonosították elsőként az ugyancsak szerkezeti fehérjeként funkcionáló PP4R2 alegységet. Ők különböző emlős izom és here szövetekböl tisztítottak nagy molekulasúlyú (450 és $600 \mathrm{kDa}$ ), katalitikus és R2 alegységet sztöchiometrikus arányban tartalmazó heteromer komplexeket. A nagy molekulasúly oka a PP4R2 dimerizációja és a komplex strukturális aszimmetriája. Ugyancsak ez a csoport írta le elsőként, hogy az R2 alegység feltehetőleg a katalitikus alegység centroszómához való lokalizációjában és aktivitásának szabályozásában is szerepet játszik, elsőként utalva a PP4 lehetséges szerepére a sejtciklusban [34]. 

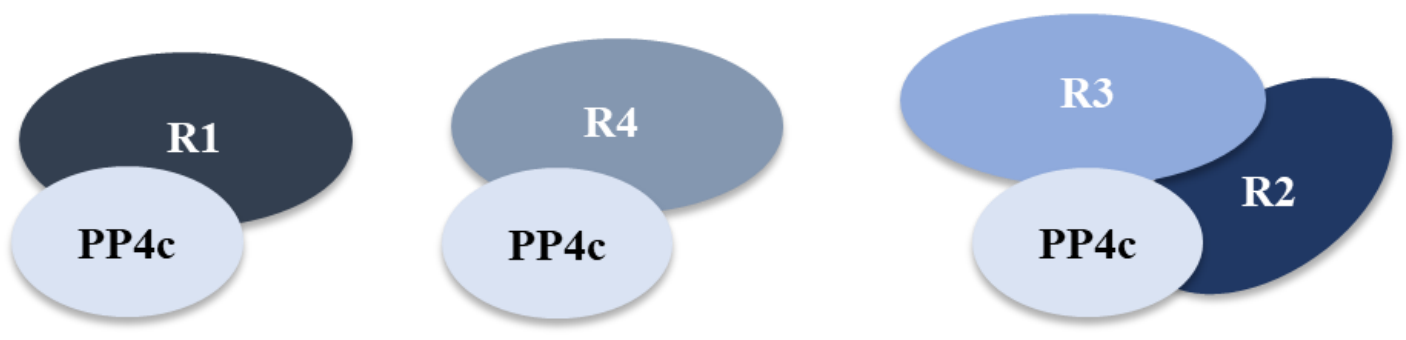

3.ábra. A leggyakoribb PP4 holoenzimek és alegység összetételük sematikus ábrája. A PP4 a sejtekben heterodimer vagy heterotrimer holoenzim formájában fordul elö. A PP4 heterotrimer holoenzim élesztötől emlösökig leggyakoribb formáját a PP4c, R2 és R3 alegységek alkotják. Ebben a formában az R2 alegység egy szerkezeti fehérjeként funkcionál, biztosítva a katalitikus és az R3 alegység kapcsolódását. A szubsztrátum felismerésért és kötésért az R3 alegység felelős.

Az R3 alegység ortológjai evolúciósan erősen konzerváltak élesztőtől az emberig [41-44]: élesztőben Psy2 (platinum sensitivity 2) [45, 46], Drosophilában Falafel (Flfl) [47], emberben R3 $\alpha /$ SMEK1 és R3ß/SMEK2 (supressor of MEK1) [41]. Domén felépítésük is nagy hasonlóságot mutat. Az amino-terminális végen egy konzervált Pleckstrin homology $(\mathrm{PH})$ superfamily-like családba tartozó EVH1 (enabled/VASP homology 1) domént hordoznak. Ezt a kizárólag az R3 ortológokban megtalálható, erősen konzervált, de ismeretlen funkciójú Smk-1/DUF625 (domain of unknown function 625) követi. A fehérje középső részét változó számú ARM (armadillo/HEAT) ismétlődések foglalják el, melyek, mint fontos szerkezeti elemek szerepet játszhatnak intermolekuláris kölcsönhatások kialakításában. Az ARM ismétlődéseket a rendezetlen szerkezetű C-terminális vég követi, melynek hossza fajonként eltérö lehet (4. ábra) [48].

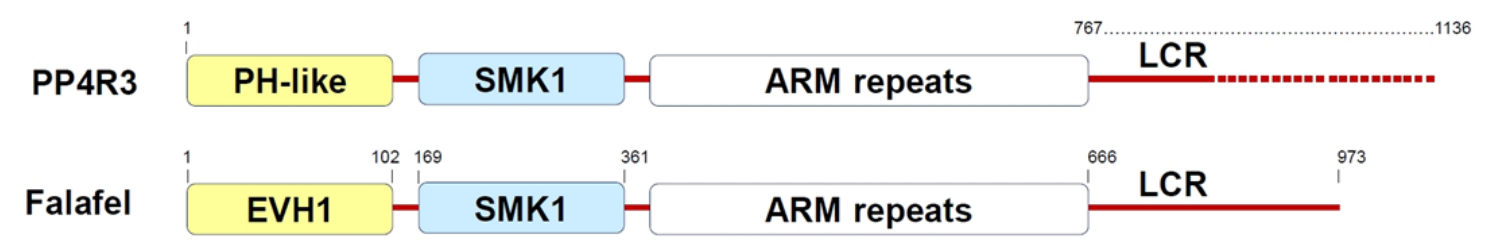

4.ábra. Az emberi és a Drosophila $\mathrm{R3}$ alegység sematikus képe és domén elrendezése (ábra részlet, Lipinszki és mtsai, 2015, [48]). Mindkét fehérje egy konzervált PH/EVH1-like domént és egy ismeretlen funkciójú Smk-1 domént hordoz az N-terminális részen. Ezt a fehérje középső részén Armadillo/HEAT ismétlődések (ARM) követik, illetve a fehérje C-terminálisán egy változó hosszúságú, alacsony komplexitású régió (LCR).

A fent leírt alegységek mellett fontos megemlítenünk még a több ráktípusban is megemelkedett szintet mutató a4-et (Tap42 Drosophila-ban (Two A-associated protein $42 \mathrm{kDa})$ ). Ez a fehérje stabilizálja a PP2A-típusú foszfatázok szabad katalitikus alegységét $[49,50]$, ezzel időt adva a megfelelő térszerkezet kialakulására, amíg más 
alegységekkel összekapcsolódva létre nem hoz egy stabil holoenzim komplexet [50]. Az a4/Tap42 közös gátlószere a PP2A, PP4 és PP6 katalitikus alegységeknek, azonban a PP2A és PP6-tal ellentétben, a PP4 esetében még nem teljesen ismert ennek pontos molekuláris mechanizmusa [51, 52]. Az aktivitás gátlása mellett az $\alpha 4 /$ Tap42 ezen foszfatázok kifejeződésének mértékét is szabályozza [49]. Növényekben tudjuk, hogy az a4 mellett a CCT chaperonin komplex is fontos regulátora a PP4c stabilitásának, a CCT hiányos állapot a PP4c fehérje szint jelentős csökkenéséhez vezet [50].

A PP4 természetesen a fehérjék többségéhez hasonlóan szigorúan szabályozott különböző poszttranszlációs módosítások révén is. Ezek közül az egyik legjelentősebb a katalitikus alegység extrém konzervált C-terminális leucin oldalláncának karboximetilációja [39, 53, 54]. A leucin karboxil metiltranszferáz 1 által metilált 307-es leucin mutációja (L307A) esetén a katalitikus alegység részben aktív marad, de a nagyfokú aktivitás csökkenés és az R3 regulátor alegységekkel való kapcsolódás elvesztése miatt sérül az enzim biológiai funkciója [53]. Érdekes, hogy a PP4c aktivitáscsökkenése mellett a leucin karboxil metiltranszferáz 1 kiütése a PP4R1 szint csökkenésével is jár egér embrionális fibroblaszt sejtekben [54], ami hiszton-deacetiláz 3 hiperfoszforilációhoz vezet a PP4c/PP4R1 komplex hiánya miatt. A metilációs hely mellett $\mathrm{Hu}$ és munkatársai azonosítottak lehetséges O-glikozilációs és N-mirisztilációs helyeket is, melyek befolyásolhatják a PP4c lehetséges kölcsönható partnereit, ezáltal az enzim aktivitását és sejten belüli lokalizációját [55]. A katalitikus alegység mellett az R2 és R3A alegységek $\mathrm{G}_{2} / \mathrm{M}$ fázisban $\mathrm{Cdk} 1 /$ cyclin-B általi tranziens foszforilációja is a PP4 csökkent katalitikus aktivitását eredményezi, míg ezen alegységek foszforilációja nem befolyásolja a katalitikus alegység lokalizációját [56].

A PP4 legtöbb alegysége nagyfokú evolúciós konzerváltságot mutat az eukarióták között. Az emberi PP4c az egérrel 100\%-os [57], a nyúllal 99,3\%-os [58], a gömbhallal 99\%-os [59], a zebrahallal 98\%-os [60], a Drosophila-val 91\%-os [61] azonosságot mutat az aminosav szekvencia szintjén, amely vetekszik a hisztonokra jellemző konzerváltsággal. A PP4 alegységek ortológjait megtalálhatjuk élesztőben is $(\mathrm{PP} 4 \mathrm{c}=\mathrm{Pph} 3$, Psy4=R2, Psy2=R3), ahol bármely alegység deléciója megnövekedett ciszplatin és oxaliplatin (tumorellenes szerek) érzékenységhez vezet [62], azonban a magasabbrendű eukariotákkal ellentétben a Pph3 nem kötődik a centroszómához és a deléciója is életképes [63]. Élesztőben a Psy2 alegység fontos komponense a DNS hibajavításnak [64, 65]. A regulátor alegységek mellett a katalitikus alegység két ortológját is (PPX-1/PP4.1 és PPX-2/PP4.2) megtalálhatjuk növényekben, ahol minden 
szövetben kifejeződik, legnagyobb mértékben a gyökér epidermiszének plasztiszaiban [66]. A PP4 megtalálható Dictyostelium-ban is, ahol is nélkülözhetetlen a fejlődés, helyváltoztatás és a stresszválaszban szerepet játszó gének kifejeződésének szabályozásában [67]. A PP4c magasabbrendű eukariótákban a legtöbb szövettípusban kifejeződik, legmagasabb szinten a herékben, vesében, idegsejtekben, májban és tüdőben [55]. Számos organizmusban a kifejeződési mintázata változik a fejlődési során, tehát fontos szerepet tölt be az ontogenezis szabályozásában is [55, 60, 68, 69].

\subsection{A PP4 foszfatáz szabályozó szerepe különböző folyamatokban}

\subsubsection{Sejtciklus és sejtosztódás}

A PP4 foszfatáz fontos szabályozója mind a mitotikus, mind a meiotikus osztódás számos eseményének, úgymint a centroszómák érése, a mitotikus orsó összeszerelődése, a stabil mikrotubulus/kinetokór kapcsolatok kialakulása, a homológ kromoszómák párba állása, a rekombináció eseménye, a testvér kromatidák szétválása és a citokinézis.

1992-ben Dolah és Ramsdell megfigyelt egy okadainsav érzékeny foszfatázt, ami szükséges a mitotikus orsó összeszerelődéséhez. Ez a foszfatáz nagy valószínűséggel az akkor még nem ismert PP4 lehetett [70]. Helps és munkatársai létrehoztak ecetmuslicában egy olyan $\mathrm{PP} 4 \mathrm{c}$ hipomorf mutációt $(\mathrm{cmm}$, centrosome minus microtubules), ahol a PP4c mRNS és fehérje szintje is nagymértékben csökkent korai szinciciális embriókban. A mutánsokban több olyan centroszóma figyelhető meg, amely nem rendelkezik jól meghatározható mitotikus orsó mikrotubulusokkal [61]. Ennek hátterében az áll(hat), hogy a PP4 defoszforilálja a $\gamma$-tubulint [56], ami így elveszíti centroszomális lokalizációját, így a mikrotubulus nukleáció sem tud megfelelően beindulni, ami viszont előfeltétele a mitotikus orsó létrejöttének [61]. A centroszómák esetében a PP4 egy nagyon specifikus lokalizációt mutat a többkomponensü pericentrioláris anyagban, több organizmus esetében [28, 34, 56, 71-73], ugyanis fontos szerepet tölt be a centroszómák érésében is. PP4 hiányában nem indul be a centroszómák érése, mert a pericentrioláris anyagban nagy mértékben lecsökken az ehhez szükséges faktorok száma [71, 72]. Ehhez hasonlóan, fonalféregben a PP4 depléció hatására ugyancsak súlyosan sérül a $\gamma$-tubulin centroszomális lokalizációja [72]. Érdekes, hogy a PP4 kiütése mellett a PP4 túltermelés is kromoszóma párosodási és orsó összeszerelődési hibákhoz vezet [74]. C. elegans-ban a MEI-1 fehérje aktivitása nélkülözhetetlen a meiotikus orsó kialakulásához, míg meiózis után fontos az inaktiválása, hogy az első 
mitotikus orsó is kialakulhasson. Az egyedfejlödés során a PP4c/PP4R1 komplex az egyik közvetlen aktivátora ennek a fehérjének [75]. C. elegans-ban a PP4 tehát nélkülözhetetlen a spermiumok mitotikus és meiotikus, illetve az oogenezis meiotikus osztódásai során [72].

Fontos megemlítenünk az egyik legfontosabb mitotikus kináz, a CDK1/ciklin B komplex hatását a PP4-re. A $\mathrm{G}_{2} / \mathrm{M}$ fázisban a PP4 R2 és R3 alegységei több helyen is foszforiláltak a CDK1/cyclin B által, ami bár nem befolyásolja a PP4c lokalizációját, de nagyban csökkenti a foszfatáz aktivitását az $M$ fázisban, míg a mitózis végén a PP4 aktivitás közel 10-szeresére növekedhet. A mitózis során a CDK1/ciklin B gyakorlatilag inaktívan tartja a PP4-et, így a $\gamma$-tubulin foszforilált marad, ami elősegíti a mikrotubulus nukleációt a centroszómáknál. A mitózis végén a csökkent CDK1/ciklin B aktivitás és ciklin B szint, és az ezzel párhuzamosan megnövekedő PP4 aktivitás a $\gamma$-tubulin defoszforilációjához és a mitotikus orsó szétszerelődéséhez vezet [56]. A PP4 nem csak a CDK1 szabályozása alatt áll, de önmaga is egy negatív szabályozója a CDK1 aktivitásnak. PP4 deléciós sejtekben a CDK1 abnormális aktivitást mutat az interfázisban, ami NDEL1 hiperfoszforilációhoz vezet. Ez a katanin p60 szintjének növekedéséhez és a mikrotubulusok instabilitásához vezet a centroszómáknál [76].

A PP4c/R2/R3 komplex a centroszómák érésének és a mikrotubulus nukleáció és stabilitás szabályozása mellett fontos szerepet játszik a citoszkeleton szervezésében a sejtek mozgása során. A PP4c-deficiens sejtek mozgása súlyosan sérül az epidermális növekedési faktor által aktivált Rac1 és Cdc42 Rho GTPázok inaktivitása, és az ennek hatására a mozgás irányába néző sejtmembránnál lecsökkent F-aktin szint következtében [71].

A PP4 a mitotikus orsónak nem csak a centroszómák felőli végénél, hanem a kromoszómák centroméra és kinetokór régiójában is fontos szerepet lát el. A megfelelő kinetokór-mikrotubulus kapcsolatok kialakítását a PP4 a Scaffold attachement factor A-val közösen szabályozza, de ennek pontos mechanizmus még nem ismert [74]. Lipinszki és munkatársai kimutatták, hogy Drosophila sejtekben a PP4 Flfl (R3) alegysége az EVH1 doménjén keresztül egy kulcsfontosságú centromérikus fehérjéhez, a CENP-C-hez viszi a PP4-et. Ez biztosítja, hogy a PP4 aktivitás a CENP-C és a hozzá kapcsolódó (pl. kinetokór) fehérjék szabályozása révén azokat a kromoszómákhoz kötött formában tartsa a mitózis alatt - garantálva ezzel a centroméra/kinetokór integritását [48, 77]. A PP4 a centromérák párosodását is befolyásolja a Zip1-en keresztül a meiotikus rekombináció során. PP4 deléció hatására sem a rekombinációhoz nélkülözhetetlen 
kétszálú kromoszóma törések javítása, sem a centromérák párosodása nem történik meg megfelelően [78].

A PP4 aktivitás fontos a rekombinációs és kromoszóma szétválási események szabályozásában is mind a mitózis, mind a meiózis folyamata során. PP4 mutáns C. elegans-ban az autoszomális kromoszómák szétválása sérül, míg az X kromoszóma esetében nincs változás. A PP4 deléció nemcsak pontatlan autoszomális párosodáshoz vezet, de rekombináció történhet a nem homológok között, vagy akár egy kromoszómán belül, ami súlyos osztódási zavarokhoz vezet. Ezek a kromoszóma szegregációs problémák tovább súlyosbodnak a növekvő anyai korral [79]. Érdekes, hogy C. elegans-ban a PP4 nem szükséges a meiotikus homológ kromoszómák párba állásához, míg élesztőben ez a folyamat PP4 függő [78]. A PP4 a testvér-kromatidák szétválása során is fontos funkcióval bír. Míg a szétválás során a testvér kromatidákat összetartó kohezin komplex egy része Wpl1-függő módon eltávolítódik a kromatinról, addig egy másik része a kromatinhoz kötött marad, de a Wpl1-függő PP4 általi Rad21 defoszforiláció révén elveszíti kromatid-összetartó képességét [80].

A PP4-nek fontos szerepe van a mitózis folyamatának elején is a sejtmagmembrán felbomlásában, az ebben központi szereppel bíró BAF (Barrier-to-Autointegration Factor) fehérje foszforegulációján keresztül. A BAF a többsejtü eukarióták között evolúciósan erősen konzervált [81]. Deléciója (null mutáns) homozigóta formában letális, míg depléciója (hipomorf mutáns) súlyos kromatin szegregációs és sejtmagmembrán összeszerelödési problémákhoz vezet $[77,81,82]$. A mitózis végén a BAF defoszforilálódik a PP2A révén és ez a formája a heterokromatinhoz kötődve kölcsönhatásba lép a nukleáris laminát alkotó LEM-domént tartalmazó fehérjékkel (LAP2, EMERIN és MAN1). Ez a kapcsolat elengedhetetlen a sejtmagmembrán összeszerelődéséhez a mitózis végén és integritásának fenntartásához az interfázis folyamán. A mitózis és meiózis elején a BAF-ot a VRK1 foszforilálja, ennek következtében a BAF elveszíti kromatin és a LEM-domént tartalmazó fehérjekötő képességét, melynek hatására felbomlik a sejtmagmembrán (NEB). A mitózis végén a PP2A foszfatáz újra defoszforilálja a BAF-ot $[83,84]$. A BAF foszforegulációjában részt vesz a PP4 foszfatáz is, de ennek hatásáról keveset tudunk [77, 81-85].

A mitózis végéhez közeledve a PP4 fontos szabályozója több citokinézist irányító kináznak is (pl. Aurora B, Plk1, Mlpk 1), de ennek sem ismert részleteiben a mechanizmusa. PP4 deléciós sejtekben a mitotikus orsó hibás, több centroszóma és 
mitotikus orsó is kialakul, a mitózis hossza megnő és a citokinézis nem történik meg, ami így egy tetraploid állapot kialakulásához, majd sejthalálhoz vezet [86].

Érdekes, hogy a PP4 túl- és alul müködés is a sejtciklus abnormális lefolyásához vezethet. A látszólagos ellentmondásnak az oka az lehet, hogy a PP4 deléció/túltermelés különböző csoportok eredményei alapján más és más stádiumban állítja meg a sejtciklust, az eltérő sejtvonalak és technikák alkalmazása miatt [74]. A PP4 túltermelődését vagy hiperaktivitását számos ráktípus esetén is kimutatták [87-96].

\subsubsection{Sejt-differenciálódás és túlélés}

A PP4-nek kiemelten fontos szerepe van az idegsejtek osztódásában, túlélésében és regenerálódásában. A Drosophila agyi neuroblasztok aszimmetrikus osztódása során a PP4c/R2/R3 komplex defoszforilálja a Miranda fehérjét (amely a Prospero komplex modulátora), ezáltal szabályozva annak aszimmetrikus kortikális eloszlását [44, 97]. A PP4 hozzájárul a neuronális progenitor sejtek normális megújulásához és differenciációjához a Par3 és Mbd3 fehérjék negatív szabályozása révén $[42,98]$. Az idegsejtek túlélését szabályozó Survival of Motoneurons komplex is a PP4 regulációja alatt áll. A PP4c/PP4R2 komplex kapcsolódik a Survival of Motoneurons komplex Gemin3 és/vagy Gemin4 alkotóihoz, meghatározva annak citoplazmatikus eloszlását [99], ezáltal szabályozva a kis sejtmagi RNS-ek összeszerelődését és érését [73]. A PP4R2 alegysége differenciálódó neuronokban a sejtmagból a citoplazmába kerül, túltermelése anti-apoptotikus hatású mind normál, mind stressz-indukálta körülmények között [99].

A hiszton deacetilázoknak kritikus szerepe van a transzkripció gátlásában, ezáltal szorosan kapcsolódnak a sejtciklus és differenciáció szabályozásához is. A PP4c/PP4R1 komplex csökkenti a hiszton-deacetiláz 3 enzimatikus aktivitását a Ser 424 defoszforilációján keresztül [100,101]. Regeneratív perifériás axonsérülések esetén a megnövekedett citoplazmatikus $\mathrm{Ca}^{2+}$ szint aktiválja a PP4-et, ami a hiszton-deacetiláz 3 inaktiválása révén növeli a hiszton acetilációt, így nő a regenerációt indukáló gének expressziója, ami a sérülés regenerációjához vezet [101]. A PP4 egy másik ponton is köthető a hiszton fehérjék szabályozásához. A PP4-hiányos neuroblasztokban megnő a hiszton $\mathrm{H} 3$ foszforilált formája, ami egy abnormális sejtalakot eredményez profázisban. Ez arra utal, hogy a PP4 szükséges a H3 defoszforilációhoz is [44].

A differenciálódást és sejthalált szabályozó folyamatok közül a PP4 fontos regulátora a Wnt [102], JNK [103, 104], p53 és EGR1 [104] jelátviteli útvonalaknak is. 
A Smek1 dózis függő módon gátolja a sejt proliferációt és migrációt, különböző tumoros szövetekben és sejtvonalakban csökkent szintet mutat. Smek1 túltermelés az mTOR jelátviteli kaszkád tagjainak és a BMI-1 inaktiválása révén hatékonyan gátolja a tumor növekedést és metasztázis képződést $[105,106]$.

A PP4 hibás müködése szerepet játszhat különböző rákos megbetegedések kialakulásában, onkogénként funkcionálhat petefészekrák [87], mellrák [31, 88, 89], tüdőrák [90], pankreatitisz [91], kolorektális karcinóma [92], prosztatarák [93] és glióma [94] esetében is. A Smek1 a tumor szupresszor hatású BLU-val képes kölcsönhatásba lépni, ami tovább növeli a Smek1 pro-apoptotikus hatását. Mind a Smek1, mind a BLU csökkent kifejeződést mutat különböző petefészekrák típusokban [87]. Míg a PP4c túltermelés gátolja a proliferációt és csökkenti a mellrák sejtek metasztázisát, ezzel egyidőben növeli ezen sejtek apoptotikus aktivitástát a Bad és PEA-15 fehérjék defoszforilációján keresztül $[89,95]$. Ezekben a sejtekben a PP4R1 csendesítés szintén jelentősen gátolja a tumornövekedést és indukálja az apoptózist a PARP gátlásán és kaszpáz-3 aktiválása révén [88]. A PP4-nek nem csak a katalitikus és az R1, hanem az R2 alegysége is fontos a mellrák kialakulásában. A PP4c/R2 komplex defoszforilálja a DBC1-et (deleted in breast cancer-1), szabályozva ezzel a p53 és apoptózis indukáló hatását [31]. A PP4 katalitikus alegységének megnőtt szintje a rossz prognózis jele is lehet glióma esetén, ezen sejteket megnövekedett proliferációs, migrációs és inváziós képesség jellemzi [94]. A PP4c ugyancsak onkogénként viselkedik kolorektális karcinóma esetében is, elősegíti ezen sejtek proliferációját, növekedését és metasztázis képzését [92]. A PP4R1 csendesítése 95D tüdőrák sejtekben csökkenti a proliferációt, a kolónia képzési képességet és sejtciklus leállást okoz a $G_{0} / G_{1}$ fázisban a sejtciklus aktiváló CDK2, CDK4 és CDK6 kinázok gátlása révén [90]. Endometriózis esetén megnövekedett expressziót mutató protein foszfatáz metilészteráz 1 képes a PP4c-vel összekapcsolódni és valószínüleg demetilálja azt, így csökkentve aktivitását [96]. A PP4 deléció hatására HeLa sejtekben a kaszpáz-3 aktivitás és az apoptotikus index megnő [86].

A PP4 aktivitásának változása összefügg számos differenciációban, proliferációban és apoptózisban szerepet játszó fehérje foszforilációs állapotának és több jelátviteli útvonal aktivitásának változásával. A tény, hogy míg bizonyos fehérjék csökkent, míg mások megnövekedett aktivitást mutatnak a PP4 túltermelés hatására, remekül példázza a fehérje kinázok és foszfatázok összetett foszforegulációs hálózatát. A PP4 abnormális müködése kapcsolatba hozható számos rákos megbetegedéssel is, így a 
PP4 nem csak potenciális tumor-markerként, de lehetséges terápiás célpontként is szolgálhat a jövőben.

\subsubsection{DNS hibajavítás}

A DNS hibajavítási folyamatok egyik legfontosabb célfehérjéjét a $\gamma \mathrm{H} 2 \mathrm{AX}$-et a PP4 komplex defoszforilálja, melynek a katalitikus alegységen kívül az R2 alegység is része, ugyanis utóbbi deléciója esetén a $\gamma \mathrm{H} 2 \mathrm{AX}$ szintje jelentősen megnő [107, 108].

S. cerevisiae-ben A Pph3/Psy2 komplex képes a foszforilált formában aktív Rad53-at defoszforilálni, ezzel újraindítva a leállt replikációs villákat [109, 110]. PP4 hiányában a Rad53 elhúzódó aktivitása miatt az S. cerevisiae mellett a Candida albicans sejtek $\mathrm{S}$ fázisa is időben kitolódik, a mitózis felé csak később lépnek tovább [111]. Az, hogy mind a $S$. cerevisiae, mind a C.albicans Pph3/Psy2 [111, 112] és az ember PP4c/PP4R3 [41] komplex interakcióba lép a Rad53-mal és defoszforilálja azt, direkt bizonyíték arra, hogy a PP4 DNS hibajavításban betöltött funkciója nagymértékben konzervált az egyes fajok között.

A sejtek két úton javíthatják ki a kettős szálú DNS töréseiket: a homológ rekombináción vagy a nem homológ végek összekapcsolásán keresztül [113]. Kettős szálú DNS törés hatására az RPA2 fehérje már a homológ rekombinációs kaszkád elején nagy mértékben felgyülik a törés helyénél. A PP4c és R2 csendesítés hatására azonban az RPA2 hiperfoszforilált marad, ami gátolja a sérülés helyére való gyors lokalizációját és egyben csökkenti a homológ rekombinációs hibajavítás hatékonyságát is [29, 114]. A Pph3/Psy2 deléciós élesztő sejtek csökkent DNS hibajavítási aktivitást és életképességet mutatnak, ami arra utal, hogy a PP4 valóban esszenciális ezen hibajavító folyamatok során $[115,116]$.

Park és munkatársai nemrég azonosítottak egy fehérjét, a PP4IP-t (protein phopshatase 4 inhibitory protein), amely képes gátolni a PP4 aktivitását a holoenzim összeszerelődésének akadályozása révén. Mind a PP4IP túltermelése, mind deléciója a DNS hibajavítás sérüléséhez és a sejtek genotoxikus stresszre adott érzékenységének növekedéséhez vezet [117].

A fentieket összefoglalva tehát kijelenthetjük, hogy a DNS hibajavításban résztvevő, PP4 által szabályozott fehérjék defoszforilálása ugyanolyan fontos, mint a kinázok általi foszforilációjuk, és ugyancsak elengedhetetlen a DNS hibajavítás során a PP4 aktivitás megfelelő időbeli szabályozása is. 


\subsubsection{Jelátviteli útvonalak}

A PP4 fontos komponense több intracelluláris jelátviteli útnak. PP4 túltermelő sejtek epidermális növekedési faktor jelenlétében megnövekedett JNK (c-Jun Nterminális kináz) MAP kináz aktivitást mutatnak. A PP4 egy indirekt pozitív regulátora a JNK útvonalnak, ugyanis nincs fizikai interakció a PP4 és a JNK között, a PP4 feltehetőleg valamely JNK aktiváló kinázon fejti ki hatását [118]. A PP4-nek a TNF- $\alpha$ és NF- $\mathrm{B}$ jelátvitel során is jól jellemzet a szerepe [57, 119-122].

A PP4 különböző szinteken befolyásolhatja a génkifejeződés mértékét is. Kedvezőtlen növekedési körülmények között a PP4c/PP4R3 komplex defoszforilálja a Maf1-et, ami a sejtmagba transzlokálódva kötődik az RNS polimeráz III-hoz és gátolja annak transzkripcionális aktivitását [123]. Növényekben több bizonyíték is van arra, hogy a PP4 a miRNS szinteket is képes befolyásolni [124, 125]. Érdekes, hogy növényekben a SMEK1 és SMEK2 alegységek eltérő kifejeződési mintázatot mutatnak, melynek következménye, hogy míg a SMEK1 feltehetőleg normál körülmények között szabályozza a miRNS biogenezist és a fejlődést, addig a SMEK2-nek a változó környezeti hatásokra adott válaszok szabályozásában lehet szerepe [125].

A hematopoetikus progenitor kináz 1 fontos alkotója több jelátviteli útvonalnak, például a JNK kaszkádnak. A PP4 defoszforilálja a hematopoetikus progenitor kináz 1-et, így gátolja annak ubikvitinációját és megnöveli aktivitását, ami a JNK szignalizációs útvonal aktiválásához vezet. Érdekes, hogy nemcsak a hematopoetikus progenitor kináz 1 aktivitását, de a kifejeződési szintjét is megnöveli a PP4, feltehetőleg két, egymástól független módon [126]. A PP4R2 alegysége $\mathrm{Ca}^{2+}$ függő módon képes interakcióba lépni egy kis $\mathrm{Ca}^{2+}$-kötő fehérjével, a calsensin-el. A PP4 kalcium függő szabályozása a $\mathrm{Ca}^{2+}$ kötő fehérjékkel való interakciókon keresztül egy általános mechanizmus lehet különböző jelátviteli utak szabályozásában [127].

A PP4 kiemelt szerepet játszik az egyedfejlődést irányító jelátviteli útvonalak szabályozásában is. Drosophilában a PP4 aktiválja a Notch és a Wingless (Wg) útvonalakat. A PP4c, PP4R2 vagy a Flfl alegységek kiütése Drosophila szárny diszkuszban egyaránt a Wg célgének kifejeződésének csökkenéséhez vezet [68]. A Smoothened (Smo) defoszforilációja révén a PP4 a Hedgehog jelátvitel során is esszenciális [69]. A PP4 nélkülözhetetlen a zebrahal embrió ventrális szöveteinek kialakulásához szükséges BMP jelátvitelben. BMP hatására a Smad1/Smad2 komplex a PP4-et a kromatinhoz transzlokálja, ahol a PP4 csökkenti a hiszton-deacetiláz 3 
aktivitását, ami az embrió dorzoventrális mintázatát kialakító gének megnövekedett kifejeződése révén hozzájárul a megfelelő egyedfejlődés végbemeneteléhez [60].

\subsubsection{Immunrendszer}

A PP4 egyaránt nélkülözhetetlen a normál sejtes és humorális immunválasz kialakítása szempontjából a T és B sejtek szabályozásán keresztül. A PP4 hibája egyaránt vezet az éretlen pre-B sejtek számának csökkenéséhez [128] és nem megfelelö érésükhöz [129]. A PP4 hiányos B sejtekben a sejtciklus haladása is abnormális, melynek hátterében a nem megfelelő immunglobulin rekombináció következtében fellépő DNS replikációs stressz áll [128-130].

A PP4 deficiencia a B sejtekhez hasonlóan a T sejtek esetében is az érés és a proliferáció visszaeséséhez, illetve a mutációs ráta és az apoptózis mértékének növekedéséhez vezet [131-135]. A PP4 T limfocitákban fontos proapoptotikus szereppel rendelkezik [135]. PP4 hiányában a pre-TCR jelátvitel során csökkent ERK aktiváció hatására csökken a T sejtek pozitív szelekciója [131]. A PP4 a B sejtek mellett a T sejtek populációjának fenntartásához is nélkülözhetetlen a nyirokszervekben [131]. A PP4 hiányos T sejtek jelentősen kevesebb IL-2-t termelnek [132]. Ezek mellett a PP4 ugyancsak esszenciális a gyulladásos és autoimmun betegségek megelőzésében a végrehajtó T sejtek aktivitását szabályozó Treg sejtek érésének megfelelő biztosítása révén, ugyanis a PP4 kiütése a Treg sejtekben részleges $\alpha \beta$ T lymphopenia és bélgyulladás kialakulásához vezet [133].

Ezek alapján kijelenthetjük, hogy a PP4 megfelelő müködése nélkül a B sejtek csökkent számuk és izotípus-váltási hibáik miatt nem képesek megfelelő humorális immunválaszt kialakítani, míg a T sejtek nem megfelelő érése és aktiválódása révén a sejtes immunválasz is sérül, vagyis a PP4 foszfatáz nélkülözhetetlen az adaptív immunrendszer megfelelő müködéséhez.

\subsubsection{Metabolizmus}

A PP4-nek fontos szerepe van több metabolikus folyamat szabályozásában is. Élesztőben glükóz megvonás hatására a Pph3/Psy2 komplex defoszforilálja a protein kináz A által foszforilált Mth1-et, amely az élesztő glükóz transzporter gének (HXT-k) Rtg1-mediált represziójához vezet [43]. A PP4 evolúciós konzerváltságából adódóan nem csak az élesztő, hanem a magasabbrendű eukarióták glükóz metabolizmusának is fontos szabályozója. Mind éhezés, mind inzulinrezisztenciás állapot hatására megnő a 
SMEK1 és SMEK2 expressziós szintje a májban, amely megemelkedett glükóz szinthez vezet [136]. Inzulinrezisztencia modellekben TNF $\alpha$ kezelés hatására a PP4 expressziója és stabilitása csökken [137], amely a glikogén szintézis csökkenéséhez vezet [138].

A glükóz metabolizmus mellet a PP4 két különböző módon, az acetil-koenzim A karboxiláz 1 aktiválás és az AMP-aktivált protein kináz $\mathrm{Ca}^{2+}$ függő inaktiválása révén is befolyásolja a máj zsíranyagcseréjét $[139,140]$.

A glükóz és zsíranyagcserék szabályozásán kívül a PP4 hozzájárul az ionháztartás fenntartásához is. Egér vesében a disztális nefronok tubuláris részén a PP4 gátolja a $\mathrm{Na}^{+} / \mathrm{Cl}^{-}$kotranszporter (NCC) aktivitását, így befolyásolva a vesében a $\mathrm{NaCl}$ visszaszívás mértékét [141].

\subsection{A fehérje foszfatázok szubsztrátum-felismerése}

A sejtek alapvető müködésében betöltött szerepük ellenére a legtöbb PPP esetében még mindig nem ismert, hogyan választják ki a szubsztrátumaikat. Néhány esetben már sikerült azonosítani azokat a konzervált konszenzus kötőmotívumokat, melyek meghatározzák a foszfatáz specificitását a katalitikus alegységen keresztül közvetlen vagy közvetett módon, egy szubsztrátum specifikus regulátor fehérje segítségével [48, 142-147]. Ezek a kötőmotívumok az úgynevezett rövid lineáris motívumok (SLiM, short linear motif) közé tartoznak. A SLiM-ek a fehérjék alapvetően rendezetlen részein helyezkednek el, általában egy rövid, körülbelül 10 aminosav hosszú fehérjeszakaszt jelentenek, melyen belül pár, evolúciósan erősen konzervált aminosav helyezkedik el [148, 149]. A SLiM-ek nem minden esetben cisz-hatású elemek, azaz jelenlétük nem feltétlenül elegendő egy adott foszfatáz dokkolásához. Még nem teljesen értjük, de feltételezhetően a SLiM-ek környezete és a fehérje szerkezete is befolyásolhatja ezt a tulajdonságot. Ezeknek a motívumoknak az ismerete lehetőséget ad a PPP-k és szubsztrátumaik kölcsönhatásának precíz manipulációjára, ezáltal az egyes folyamatokban betöltött funkciójuk vizsgálatára.

$\mathrm{Az}$ intenzíven kutatott foszfatázok esetében, mint a PP1, PP2A és PP2B a regulátor alegység és szubsztrátum felismerésért felelős SLiM-ek jól ismertek [146], a szabályozás nagyon precízen valósul meg ezen régiók poszttranszlációs módosításával [150]. A PP1 foszfatáz számos szubsztrátuma tartalmazza az RVxF motívumot, ami a PP1c katalitikus zsebének közelében lévő hidrofób árokba kötődik [151, 152]. Némely esetekben az RVxF motívum közelében, attól N-terminális irányban egy SILK vagy 
MyPhoNe motívum is lehet, ami szubsztrátumtól függő módon befolyásolhatja a kötődés erősségét [143]. A PP2B katalitikus alegysége szintén a regulátor alegységeitől függetlenül, direkt módon köti meg az LxVP és PxIxIT SLiM-eket [145, 153]. A PP2A SLiM felismeréséért a regulátor alegységek felelősek. A PP2A-B56 az LSPIxE motívumot ismeri fel, míg a PP2A B' alegységei $(\alpha, \beta, \gamma 1, \gamma 2, \gamma 3, \delta$ és $\varepsilon)$ az LxxIxEx motívum felismerését teszik lehetővé [146]. Mint a sejtciklus egyik fő szabályozója, a PP2A-B55 komplex a szubsztrátumait egy elektrosztatikus kölcsönhatáson alapuló módon ismeri fel, ami feltehetően a foszfatáz felszínén lévő savas aminosavak és a szubsztrátum felszínén található, bázikus aminosavakból álló úgynevezett BPR (bipartite polybasic recognition determinant) között jön létre, bár erre direkt kísérletes bizonyíték nincs [142].

A PP4 leggyakrabban három alegységes komplexként (PP4c-R2-R3) funkcionál a sejtben, melyben nagy valószínűséggel az R3 alegység EVH1 doménjén keresztül köti meg a szubsztrátumait. A kanonikus EVH1 domének prolin-gazdag szekvenciákhoz kötődnek [154], amiből logikus lenne a következtetés, hogy az R3 ortológok is magas prolin tartalmú SLiM-eket ismernek fel. Nemrégiben Ueki és munkatársai meghatározták a humán PP4 konzervált szubsztrátum felismerési motívumát [155], mely eredmények egybevágnak a mi felfedezéseinkkel Drosophila-ban. A PP5, PP6 és PP7 foszfatázok esetében a szubsztrátum felismerésért felelős motívumok még nem ismertek. 


\section{CÉLKITÜZÉSEK}

A PP4 a sejtműködés folyamatainak esszenciális szabályozója. A különböző regulátor alegységein keresztül számos fehérjével interakcióba lép, munkánk kezdetekor azonban a szubsztrátum felismerésének módja még nem volt ismert. A PP4 szubsztrátum felismerésének vizsgálatához Drosophila modellorganizmusban a következő célokat tüztük ki:

1.) a Falafel alegység konzervált doménjeinek segítségével új PP4 interakciós fehérjék azonosítása

2.) az új interakciós partnerek és a Falafel domének közötti lehető legkisebb kölcsönhatási felület meghatározása

3.) az új eredmények és a szakirodalomban igazolt interakciós fehérjék segítségével meghatározni a szubsztrátum felismerésért felelős konzervált konszenzus szekvenciát

Az előbb felsorolt célok vizsgálatával nem csupán jobban megérthetjük a PP4 sejt homeosztázis-szabályozásában betöltött szerepét és szubsztrátum felismerésének lehetséges módjait, hanem egy konzervált szubsztrátum felismerési motívum a további potenciális PP4 szubsztrátumok azonosítását is nagyban megkönnyítené, valamint PP4specifikus kis molekulasúlyú gátklószerek kifejlesztését tenné lehetővé. Ez utóbbi az alakultatások mellett terápiás célokat is szolgálhatna. 


\section{ANYAGOK ÉS MÓDSZEREK}

\subsection{DNS konstrukciók és klónozás}

A kísérletekben felhasznált fehérjék cDNS-eit a Drosophila Gene Collection-ből (Berkeley Drosophila Genome Project, Drosophila Gold Collection) szereztük be.

A T7 promotert tartalmazó pOT2 vektorban [156] lévő cDNS-eket szubklónozás nélkül felhasználhattuk az IVTT (in vitro transzkripció/transzláció) reakciókban. A más vektorokban (pBS SK-, pOTB7, pFlc-1) lévő géneket a pHY22 plazmidba [157] klónoztuk, amely alkalmas a T7 promoter alapú IVTT-re (lásd lentebb). Azokban az esetekben, ahol nem volt elégséges a fehérje expresszió, T7 promotert tartalmazó PCR fragmenteket hoztunk létre (T7 promoter-Kozak szekvencia-ATG-génspecifikus szekvencia-3xSTOP) és ezeket közvetlenül használtuk az IVTT reakciókban. Az interakciós felületek térképezése során a fehérjék átfedő darabjait kódoló szakaszokat pHY22-be klónoztuk vagy PCR fragmentet hoztunk létre a fent említett módon.

A kísérletekben felhasznált próba fehérje darabokat (EVH1, SMEK1_EVH1 és Smk-1) PCR segítségével amplifikáltuk és pDONR221 entry plazmidokba klónoztuk Gateway rendszerrel (Life Technologies), majd N-terminális GST fúziós fehérjét tartalmazó pDEST15 plazmidba illesztettük. Az EVH1 ${ }^{\mathrm{L} 70 \mathrm{~A}}$ és SMEK1_EVH1 ${ }^{\mathrm{L} 69 \mathrm{~A}}$ próba fehérjéket kódoló DNS-eket a korábban létrehozott pDONR221-EVH1 és pDONR221-SMEK1_EVH1 plazmidokról helyspecifikus mutagenezissel hoztuk létre a Takara QuickChange II XL Site-Directed Mutagenesis Kit (Agilent Technologies) segítségével.

A próba és a vizsgálni kívánt fehérjéket PCR segítségével amplifikáltuk és pDONR221 (Invitrogen) entry plazmidokba klónoztuk Gateway klónozási rendszerrel. Fehérje expresszióra pAGW, pAFW (Drosophila Gateway Vector collection), pMTeGFP és pMT-3x-Flag plazmidokat [48] használtunk.

A BAF vizsgálatához az RNS interferencia-rezisztens $\left({ }^{\mathrm{R}}\right)$ GFP::CENP-C $\mathrm{C}^{\mathrm{R}}$ és GFP::CENP-C $\triangle$ FIM $^{\mathrm{R}}$ létrehozásához kicseréltük a GFP::CENP-C és GFP::CENP-CAFIM konstrukciók [48] Acc651I-EcoRI (420 bázispár) szakaszát egy kodon-módosított verzióra (GeneArt), ami ugyanazokat az aminosavakat kódolja, de az 
endogén CENP-C-t célzó RNS interferenciára nem érzékeny. A GFP kötő fehérjét (GBP) [158] kódoló szakaszt PCR-al amplifikáltuk és a pMT-3xFlag-DEST plazmidba a 3xFlagtag-től 5' irányba, azzal egy leolvasási keretbe klónoztuk, majd ebbe Gateway klónozás segítségével a BAF entry klónt felhasználva létrehoztuk a pMT-GBP::FLAG::BAF konstrukciót.

A Gateway oligonukleotid primerek tervezése pDONR221 entry klón létrehozásához:

Forward: 5'-GGGGACAAGTTTGTACAAAAAAGCAGGCTTA-24 nukleotid génspecifikus szakasz-3' (ATG-vel vagy anélkül)

Reverz: 5'-GGGGACCACTTTGTACAAGAAAGCTGGGTA-24 nukleotid génspecifikus szakasz-3' (STOP kodonnal)

\begin{tabular}{|c|c|c|c|}
\hline plazmid & promóter & fúziós fehérje & felhasználás \\
\hline pAGW & Act5C & N'GFP & \multirow{5}{*}{$\begin{array}{c}\text { stabil D.Mel-2 sejtvonalak } \\
\text { létrehozása }\end{array}$} \\
\hline pMT-eGFP & MT & N'GFP & \\
\hline pAFW & Act5C & N'Flag & \\
\hline pMT-3x-Flag & MT & N' Flag & \\
\hline pMT-GBP::Flag & MT & N' GFP + Flag & \\
\hline pDONR221 & - & - & Gateway klónozás entry vektor \\
\hline pDEST15 & $\mathrm{T7}$ & N' GST & fehérje termeltetés E.coli-ban \\
\hline pFlc-1 & $\mathrm{T7}$ & - & \multirow{3}{*}{$\begin{array}{c}\text { in vitro kísérletekhez használt } \\
\text { fehérjék cDNS-ének } \\
\text { átklónozásához templát }\end{array}$} \\
\hline pOTB7 & Sp6 & - & \\
\hline pBS SK- & T3 & - & \\
\hline pOT2 & $\mathrm{T7}$ & - & \multirow{2}{*}{ in vitro fehérje termeltetés } \\
\hline pHY22 & T7 & - & \\
\hline
\end{tabular}

1.táblázat. A kísérletekhez használt plazmidok listája

In vitro mutagenezis:

Az EVH1 szubsztrátum-felismerési motívumának azonosításához szükséges pontmutációkat a meglévő in vitro és in vivo kísérletekhez használt DNS konstrukciók módosításával állítottuk elő QuikChange XL Site-Directed Mutagenesis Kit (Agilent Technologies) használatával.

Az összes létrehozott DNS konstrukciót restrikciós emésztéssel és/vagy DNS szekvencia-meghatározással ellenőriztük. 


\subsection{Drosophila törzsek fenntartása és embriók gyüjtése}

A kísérleteink során felhasznált vad típusú (white ${ }^{1118}$ ) Drosophila törzset klasszikus kukoricaliszt alapú táptalajon, $25^{\circ} \mathrm{C}$-on, a cirkadián ritmusuknak megfelelő fény/sötét periódusban tartottuk. Ebből a törzsből szinkronpetéztetéssel korai (0-2 órás), mitotikusan aktív embriókat gyüjtöttünk a tömegspektrometriai analízishez.

\subsection{Stabilan transzfektált Drosophila D.Mel-2 sejtvonalak létrehozása}

A D.Mel-2 sejtek a klasszikus Drosophila melanogaster S2 sejtkultúra szérummentes táptalajhoz adaptált változatai (Thermo Fisher Scientific)[159]. Konfluens D.Mel-2 sejtkultúrát felszuszpendáltunk friss szérum-mentes, komplett médiumban (Insectagro DS2 Serum-Free/Protein-Free Medium (Corning), melyet kiegészítettünk $200 \mu \mathrm{g} / \mathrm{ml}$ L-glutaminnal és 1x PenStrep-el), 6 lyukú sejttenyésztő lemezen 2-2 ml végtérfogatban $70-80 \%$-os sejtsürüségüre hígítottuk, majd 4 órát $25^{\circ} \mathrm{C}$-on inkubáltuk. Egy Eppendorf csőbe $100 \mu 1$ Opti-MEM (Gibco) reagenshez $9 \mu 1$ Cellfectin II (Gibco) reagenst adtunk, egy másik Eppendorf csőbe pedig szintén $100 \mu 1$ Opti-MEM-hez a transzfekcióhoz szükséges mennyiségü (2-3 $\mu \mathrm{g})$, nagy tisztaságú plazmid DNS-t adtunk. Ezt követően a DNS-t tartalmazó keveréket a Cellfectin II reagenst tartalmazó csőbe pipettáztuk és 30 percig $25^{\circ} \mathrm{C}$-on inkubáltuk. A keveréket ezután óvatosan a lemezen lévő $2 \mathrm{ml}$ sejthez csepegtettük, majd $25^{\circ} \mathrm{C}$-on három napig növesztettük a sejteket. Ezután a médiumot eltávolítottuk és friss, szelekciós antibiotikumot $(20 \mu \mathrm{g} / \mathrm{ml}$ Blasticidin-S $\mathrm{HCl})$ is tartalmazó komplett médiumot adtunk a sejtekhez, majd $25^{\circ} \mathrm{C}$-on újabb 3 napig növesztettük őket. Ettől a lépéstől a szelekció fenttartásának érdekében kizárólag szelekciós antibiotikumot is tartalmazó komplett sejttenyésztő oldatot használtunk. Újabb három nap elteltével a sejtkultúrát friss médiummal kétszeres térfogatra hígítottuk és 25 $\mathrm{cm}^{2}$ (T25) flaskába pipettáztuk. A folyamatot addig ismételtük (passzálással), amíg a sejtek a kellő sejtsűrüség elérésével egy nagyobb $\left(75 \mathrm{~cm}^{2}, \mathrm{~T} 75\right)$ sejttenyésztő flaskába nem kerülhettek. A transzgén kifejeződését az innentől számított harmadik passzálás után Western-blot segítségével ellenőriztük.

\subsection{Fehérje termeltetés és tisztítás}

A tömegspektrometriai analízishez és az in vitro kötési kísérletekhez használt

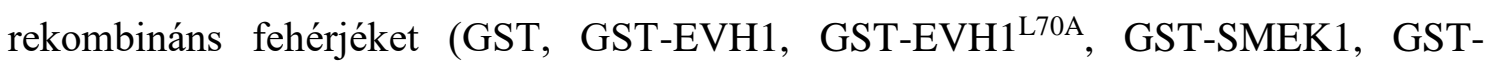


SMEK1_EVH1 ${ }^{\text {L69A)}}$ ) SixPack Escherichia coli törzzsel termeltettük [160] és tisztítottuk az alábbiak szerint. A sejteket $A_{600} \sim 0,6$-ig növesztettük, majd a fehérje termelést $1 \mathrm{mM}$ 1-tio- $\beta$-D-galaktopiranozid (IPTG) hozzáadásával indukáltuk. 5 óra $25^{\circ} \mathrm{C}$-on történő rázatás $(280 \mathrm{rpm})$ után a sejteket centrifugálással ülepítettük és hideg PBS-sel mostuk. A sejteket ezután $30 \mathrm{ml}$ pufferben (LB: PBS, 1 mM DTT, $1 \mathrm{mM}$ PMSF és 0,2 ng/ $\mu 1$ lizozim) felvettük és ultrahangos feltárással lizáltuk. A sejttörmeléket centrifugálással (16 000 xg, 15 perc, $4^{\circ} \mathrm{C}$ ) eltávolítottuk és a tiszta felülúszót Glutathione Sepharose 4B (GE Healthcare) gyöngyökhöz adtuk, majd $4^{\circ} \mathrm{C}$-on 90 percig inkubáltuk lassú forgatás mellett. Miután a gyöngyöket 4x mostuk 0,05\%-os Triton X-100 detergenssel kiegészített PBS pufferrel, a gyöngyökhöz kötődött fehérjéket 50\%-os glicerin tartalmú PBS pufferben vettük fel és $-20^{\circ} \mathrm{C}$-on tároltuk.

\subsection{Affinitás tisztításhoz kötött tömegspektrometriai azonosítás (AP-MS)}

A white ${ }^{1118}$ Drosophila törzsből gyüjtött, dekorionizált és $-80^{\circ} \mathrm{C}$-on tárolt mitotikusan aktív (mitotikus index $\sim 50 \%$ ) korai szincíciális (0-2 órás) embriókból 3-3 grammot használtunk az affinitás tisztításhoz.

Az embriókat Dounce-homogenizátor segítségével sejtfeltáró pufferben (EB1: $20 \mathrm{mM}$ Tris $\mathrm{pH} 7,5,150 \mathrm{mM} \mathrm{NaCl}, 2 \mathrm{mM} \mathrm{MgCl}_{2}, 0,5 \mathrm{mM}$ EGTA, $1 \mathrm{mM}$ DTT, 0,1\% NP40, $20 \%$ glicerin, $1 \mathrm{mM}$ PMSF (szerin proteáz gátlószer), 1 x PIC (szélesspektrumú proteáz inhibitor koktél), 25 MM MG132 (20S proteaszóma gátlószer), 1x PhosStop (szélesspektrumú foszfatáz gátlószer)), $4^{\circ} \mathrm{C}$-on tártuk fel. A feltárás után a sejttörmeléket centrifugálással $\left(12000 \mathrm{xg}, 15\right.$ perc, $\left.4^{\circ} \mathrm{C}\right)$ távolítottuk el. A tiszta felülúszó frakciót $60 \mu 1$ GST, GST-EVH1 vagy GST-Smk-1 gyöngyhöz adtuk és 2,5 órán át inkubáltuk $4^{\circ} \mathrm{C}$-on, folyamatos lassú forgatás mellett. A gyöngyöket ezután $5 \mathrm{x}$ mostuk mosó pufferrel (WB1: $20 \mathrm{mM}$ Tris pH 7,5, $150 \mathrm{mM} \mathrm{NaCl}, 2 \mathrm{mM} \mathrm{MgCl} 2,0,5 \mathrm{mM}$ EGTA, $1 \mathrm{mM}$ DTT, 0,1\% NP40, 20\% glicerin, $1 \mathrm{mM}$ PMSF), az utolsó mosást pedig egy csak sókat és EGTA-t tartalmazó pufferrel (WB2: $20 \mathrm{mM}$ Tris pH 7.5, $150 \mathrm{mM} \mathrm{NaCl}, 2 \mathrm{mM}$ $\mathrm{MgCl}_{2}, 0,5 \mathrm{mM}$ EGTA) végeztük. Az utolsó mosópuffer teljes eltávolítása után a gyöngyöket ammónium-bikarbonát $(50 \mathrm{mM})$ oldattal átöblítettük, majd $50 \mu 1$ térfogatú ammónium-bikarbonát pufferben vettük fel és tömegspektrometriai analízisre átadtuk Janusz Debski kutatócsoportjának (Biokémiai és Biofizikai Intézet, PAN, Varsó). 


\subsection{In vitro kötési kísérlet}

A fehérje-fehérje interakciós kísérletekhez a ${ }^{35}$ S-metioninnal jelölt vizsgálni kívánt fehérjéket ún. kapcsolt in vitro transzkripciós/transzlációs rendszerrel (IVTT, Promega, L1170) termeltettük. Egy $15 \mu$ l-es reakcióhoz (amely tartalmazta a T7 promoterről átírni képes transzkripciós apparátussal ellátott nyúl retikulocita lizátumot (TNT Quick Master Mix, Promega), RNáz gátlószert (RNasin, Promega), T7 PCR Enhancer-t (Promega), EDTA-mentes proteáz inhibitor koktélt (Roche), 0,3 MBq ${ }^{35} \mathrm{~S}$-L-metionint (PerkinElmer)) $50 \mathrm{ng}$ tisztított PCR terméket vagy plazmidot adtunk. A reakcióelegyet 1 órán keresztül inkubáltuk $30^{\circ} \mathrm{C}$-on, majd centrifugáltuk $(12000 \mathrm{xg}, 3$ perc, $25^{\circ} \mathrm{C}$ ). A felülúszóból $0,25 \mu 1$-t eltettünk (IVTT input), a maradékot pedig az in vitro kötési kísérlethez használtuk fel.

Közel azonos mennyiségü, Gluthatione sepharose 4B gyöngyökhöz immobilizált GST, GST-EVH1 és GST-Smk-1 próba fehérjét $1 \mathrm{ml}$ mosó pufferrel (WB3: $50 \mathrm{mM}$ HEPES pH 7,5, $150 \mathrm{mM} \mathrm{NaCl}, 2 \mathrm{mM} \mathrm{MgCl}$, 1 mM EGTA, $1 \mathrm{mM}$ DTT, 0,1\% Triton X-100) equilibráltuk. A gyöngyöket centrifugálással ülepítettük ( $600 \mathrm{xg}, 3$ perc, $\left.4^{\circ} \mathrm{C}\right)$, majd $800 \mu 1$ kötőpufferben (BB: WB3 kiegészítve proteáz inhibitor keverékkel és $0,5 \mathrm{mg} / \mathrm{ml}$ BSA-val) felszuszpendáltuk. Az IVTT reakcióelegyet egyenlően szétosztottuk a negatív kontrollként használt GST, illetve a próbaként használt GST-EVH1 vagy GST-Smk-1 gyöngyök között, majd a reakcióelegyeket 1,5 órán keresztül $4^{\circ} \mathrm{C}$-on lassú forgatás mellett inkubáltuk. Ezt követően a gyöngyöket 3x mostuk WB3, majd 3x WB4 pufferrel (50 mM HEPES pH 7,5, $200 \mathrm{mM} \mathrm{NaCl}, 2 \mathrm{mM} \mathrm{MgCl} 2,1 \mathrm{mM}$ EGTA, $1 \mathrm{mM}$ DTT, 0,2\% Triton X-100). Az utolsó mosás után a puffert teljesen eltávolítottuk, és a gyöngyökhöz 1x Laemmli mintapuffert adtunk, majd a megkötött fehérjéket 5 perces forralással eluáltuk. Forralás után a gyöngyöket centrifugálással kiülepítettük (12 $000 \mathrm{~g}$, 5 perc, $25^{\circ} \mathrm{C}$ ), majd a felülúszóban lévő fehérjéket hagyományos Tris-Glicin SDS-PAGEel (denaturáló poliakrilamid gélelektroforézis), a vizsgálandó fehérjék méretének megfelelő töménységű géleken méret szerint elválasztottuk. Az elválasztást BioRad fehérje futtató készülékkel végeztük Tris-Glicin (0,25 M Tris, 1,92 M glicin, pH 8,3-8,5) futtatópufferben. A futtatás után a géleket 10\%-os ecetsav oldattal fixáltuk és Coomassie Brilliant Blue-val festettük, majd a felesleges hátteret 10\% metanolt és $7 \%$ ecetsavat tartalmazó oldattal eltávolítottuk. A géleket gélszárító berendezés (BioRad) segítségével kiszárítottuk és dokumentáltuk. 
A vizsgálandó fehérjék jelöléséhez használt 35-ös kén izotópot tartalmazó metionin alacsony energiájú sugárzást bocsájt ki, ennek detektálásához autoradiográfiát alkalmaztunk. Az autoradiográfiát $-80^{\circ} \mathrm{C}$-on végeztük szuperérzékeny röntgenfilm (Kodak) használatával. 24-48 óra expozíciót követően a jelek detektálásához Tetenal X-ray hívó és fixáló oldatokat használtunk. Az előhívott filmeket Azure c300 géldokumentációs rendszerrel (Azure Biosystems) dokumentáltuk.

\subsection{Helyspecifikus mutagenezis}

Az FxxP és MxPP motívumok dupla aminosav szubsztitúciós mutánsait (AxxA és AxPA), illetve a Drosophila és humán EVH1 domének L70A és L69A mutánsait QuikChange XL Site-Directed Mutagenesis Kit (Agilent Technologies) használatával hoztuk létre. A $25 \mu 1$ végtérfogatú PCR reakciót a gyártó utasításának megfelelően mértük össze, melyhez templátként 5 ng tisztított plazmid DNS-t használtunk.

$\underline{\text { A PCR reakciót az alábbi módon végeztük: }}$

$-95^{\circ} \mathrm{C}, 1$ perc

-18 cikluson keresztül: 1.) $95^{\circ} \mathrm{C}, 50 \mathrm{mp}$;

2.) $60^{\circ} \mathrm{C}, 50 \mathrm{mp}$;

3.) $68^{\circ} \mathrm{C}, 1$ perc/kilobázis

$-68^{\circ} \mathrm{C}, 7$ perc

A PCR reakció után a reakcióból $2 \mu 1$ térfogatot kontrollként kémiai kompetens E. coli DH5 $\alpha$ sejtekbe juttattuk. A maradék reakcióhoz $2 \mu \mathrm{l}$ (10U) DpnI enzimet adtunk és 2 órán keresztül $37^{\circ} \mathrm{C}$-on inkubáltuk. A DpnI csak a metilált DNS-t képes emészteni, így a templátként szolgáló, baktériumsejtekből tisztított plazmid DNS-t el tudtuk távolítani a reakcióból, míg a PCR során szintetizálódott (nem metilált) nick-elt plazmidok intaktak maradtak. A 2 órás emésztés után a reakcióból $2 \mu 1$ térfogatot DH5 $\alpha$ sejtekhez adtunk, majd a sejteket $37^{\circ} \mathrm{C}$-on növesztettük. A másnap megjelenő kolóniákból DNS-t tisztítottunk, majd tesztemésztés és DNS szekvencia meghatározás segítségével ellenőriztük a kívánt mutáció létrejöttét és a szekvencia további részeinek változatlanságát.

\subsection{Ko-immunprecipitáció (Co-IP) D.Mel-2 sejtekből}

Az in vivo interakciós kísérletekhez a sejteket a transziens transzfekció után 48 órával gyüjtöttük, majd óvatos pipettázással felszuszpendáltuk, centrifugáltuk (500 g, 5 perc, $25^{\circ} \mathrm{C}$ ) és PBS pufferrel mostuk. A sejteket ezután felvettük $500 \mu 1$ extrakciós 
pufferben (EB2: $50 \mathrm{mM}$ HEPES pH 7,5, $150 \mathrm{mM} \mathrm{NaCl,} 2 \mathrm{mM}$ EGTA, $2 \mathrm{mM} \mathrm{MgCl}$, 0,1 \% NP-40, 5\% glicerin, $1 \mathrm{mM}$ DTT, $1 \mathrm{mM}$ PMSF, $25 \mu \mathrm{M}$ MG132 és $0,1 \mu \mathrm{l} / \mathrm{ml}$ Bensonase Nuclease (Merck Millipore)). A sejtek feltárásához $4^{\circ} \mathrm{C}$-on dolgoztunk, a sejtszuszpenziót 10x átpasszíroztuk $24 \mathrm{G}$ méretü tűn inzulinos fecskendő segítségével, majd 20 perc $4^{\circ} \mathrm{C}$-on történő inkubálás után a folyamatot megismételtük. A sejt lizátumokat centrifugáltuk (16000 xg, 10 perc, $\left.4^{\circ} \mathrm{C}\right)$. A felülúszóból $10 \mu 1$-t kivettünk és $10 \mu 1$ 1x Laemmli mintapuffert adtunk hozzá, (input, 2\%) majd 5 percig forraltuk. A maradék felülúszót mágneses agaróz GFP-trap (Chromotek) gyöngyökhöz adtuk és 1 órán át inkubáltuk $4^{\circ} \mathrm{C}$-on. A gyöngyöket ezután $5 \mathrm{x}$ mostuk mosó pufferrel (EB2 puffer MG132 és Bensonase Nuclease nélkül). Az utolsó mosás után a puffert eltávolítottuk, a gyöngyökhöz 1x Laemmli mintapuffert adtunk és 5 percig forraltuk. Centrifugálás után a mintákat SDS-PAGE-el elválasztottuk majd Western-blot segítségével vizsgáltuk az interakciók meglétét vagy hiányát.

\subsection{Western blot}

A ko-immunprecipitációk mintáit hagyományos Tris-Glicin SDS-PAGE-el, a vizsgálandó fehérjék méretének megfelelő töménységü géleken, méret szerint elválasztottuk. Az elválasztást BioRad fehérje futtató készülékkel végeztük Tris-Glicin futtatópufferben. Az elválasztás után a fehérjéket PVDF (polivinilidén fluorid, Merck Millipore) membránra blottoltuk (20 V, 1 óra) BioRad Trans-Blot SD Semi-Dry Transfer Cell készülék segítségével, Semi-Dry transzfer puffert alklamazva (50 mM Tris pH 7,5, $40 \mathrm{mM}$ glicin, 20\% metanol, 0,04\% SDS).

A blottolás után a membrán szabad fehérjekötő felületét 5\%-os tejpor tartalmú TBST (TBS $+0,05 \%$ Tween 20 ) oldatban inkubáltuk 30 percig $25^{\circ} \mathrm{C}$-on. A blokkolás után a membránt 5 percig mostuk TBST-vel, majd 1 órán keresztül $25^{\circ} \mathrm{C}$-on inkubáltuk az adott epitópra (GFP vagy Flag) specifikus, megfelelő mértékben hígított elsődleges ellenanyagot tartalmazó oldatban (TBST+1\% BSA). A membránt ezután 3 x 10 percig mostuk TBST oldattal. A kísérleteink során használt GFP ellenanyag (anti-GFP antibody (HRP), Abcam, ab190584) HRP-vel konjugált, ezért ebben az esetben nem volt szükségünk másodlagos ellenanyagra. A kísérleteink során használt Flag ellenanyagot (anti-Flag $\mathrm{M}_{2}$, Sigma, F1804-200UG) egérben termeltették, ezért másodlagos ellenanyagnak kecskében termeltetett, HRP-konjugált egér elleni ellenanyagot (Polyclonal goat anti-mouse IgG/HRP, DAKO, P0447) használtunk megfelelően hígítva ( 1 óra, $25^{\circ} \mathrm{C}$ ). A membránt ismét $3 \times 10$ percig mostuk TBST oldattal. A membránokhoz 
ezután Immobilon kemilumineszcens HRP szubsztrátot adtunk (Merck Millipore, WBKLS0500), majd a HRP által katalizált reakcióból keletkező fényt Azure c300 géldokumentációs rendszer (Azure Biosystems) használatával detektáltuk. 


\section{EREDMÉNYEK}

\subsection{Lehetséges PP4 interakciós partnerek azonosítása}

A szakirodalomból több olyan Drosophila fehérjét is ismerünk, melyek a PP4 foszfatáz szabályozása alatt állnak, az enzim és a szubsztrátum fehérje közötti fizikai interakció kísérletesen is bizonyított. Azonban ezen fehérjék többsége a PP4 R1 és R2 regulátor alegységein keresztül, vagy direkt módon a katalitikus alegységhez kapcsolódik. Drosophilában csupán két PP4 szubsztrát fehérje, a CENP-C és a Miranda R3 alegységhez való kötődése bizonyított kísérletesen [44, 48]. Egy konzervált szubsztrátum felismerési motívum azonosításához azonban szükségünk van több interakciós fehérje ismeretére.

Ahhoz, hogy a PP4 foszfatáz Falafel/R3 alegységén keresztül kötődő új interakciós partnereit azonosítsuk, tömegspektrometriai analízist végeztünk. Témavezetőm korábbi eredményeiből tudjuk, hogy a GST-Flfl-el végzett affinitás tisztítással és tömegspektrometriai analízissel (AP-MS) csak nagyon kevés kölcsönható fehérjét lehetséges azonosítani. Ennek oka feltehetően az, hogy az interakció a foszfatáz és a szubsztrátum között tranziens, vagyis a defoszforiláció után a PP4 elengedi a szubsztrátumát. Ezen probléma kiküszöbölésére a teljes hosszúságú Flfl helyett csupán kisebb, funkcionális egységeit (EVH1 és Smk-1 domének) használtuk az AP-MS analízishez. Ezen domének önmagukban képtelenek a másik két alegységgel összekapcsolódva funkcionális holoenzimet alkotni, azonban feltételeztük, hogy az interakciós partnereikkel stabil kapcsolatot képesek kialakítani. Lipinszki és munkatársai korábbi munkájából tudjuk [48], hogy az EVH1 domén nagyfokú konzerváltságot mutat és bizonyítottan szerepet játszik a szubsztrátum felismerésben és kötésben. Vizsgálatainkba azért vontuk be az Smk-1 domént is, mert az EVH1-hoz hasonlóan ez is erősen konzervált az R3 ortológokban (és csak ott fordul elö), ami alapján feltételezhetjük, hogy hasonlóan fontos szerepe lehet az R3/Flfl (és a PP4) funkciójában. Erről azonban a mai napig nem jelent meg irodalmi adat.

A Drosophila egyedfejlődése során, miután a nőstény lerakta a megtermékenyített petéit, a petében az első 13 osztódás során egy körülbelül 6000 sejtmagból álló ún. szincícium jön létre [161]. Mivel ezen mitotikus sejtmagi osztódások tökéletes szinkronban történnek, ezért az embriók gazdag forrásai a mitotikus fehérjéknek. Vad típusú (white ${ }^{1118}$ ) Drosophila törzsből szinkronpetéztetéssel korai szincíciális embriókat gyüjtöttünk, majd az ezekből származó teljes sejt-lizátumot affinitás tisztítás során a GST 
fúziós fehérjével jelölt Flfl doménekkel (GST-EVH1, GST-Smk-1) együtt inkubáltuk. Negatív kontrollnak GST fúziós fehérjét használtunk. A gyöngyökön immobilizált fehérjéket ezután tömegspektrometriai vizsgálatnak vetettük alá.

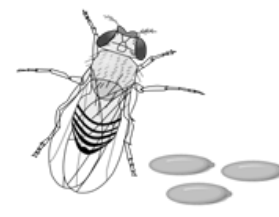

embriók gyũjtése

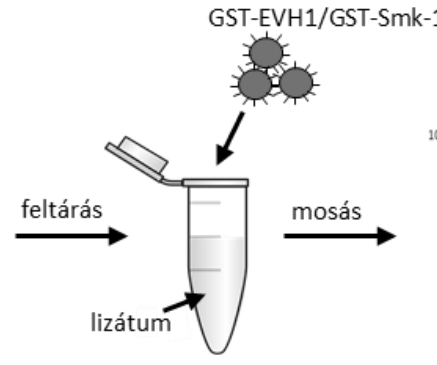

affinitás tisztítás

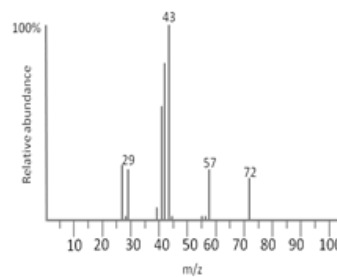

tömegspektrometriai analízis

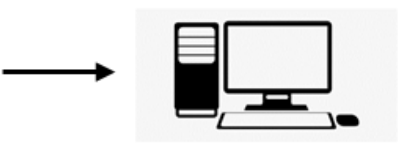

kiértékelés

5. ábra. Az affinitás tisztításhoz kötött tömegspektrometriai elemzés (AP-MS) munkamenete. A Drosophila embriókból származó lizátumot a kitisztított és gyöngyökön immobilizált GST, GST-EVH1 vagy GST-Smk-1 fehérjékkel inkubáltuk együtt. Az aspecifikusan kötődő fehérjéket több mosási lépéssel eltávolítottuk, majd az oszlophoz kötődve maradt fehérjéket tripszines emésztést követően tömegspektrometriai analízis segítségével azonosítottuk.

A tömegspektrometriai eredmények alapján 40 olyan fehérjét azonosítottunk, melyek valamely doménhez kötődtek, de főleg az EVH1-gyel mutatak kölcsönhatást (2. táblázat). Ez nem meglepő, ugyanis mint korábban említettük, az EVH1 funkciója ismert a szubsztrátum felismerésben és kötésben is. Ami sokkal inkább meglepő volt, hogy számos olyan fehérjét is azonosítottunk, amelyet kizárólag az Smk-1 domén kötött meg (2. táblázat). A két domén által megkötött fehérjék között főleg olyan proteineket találtunk, melyek különböző mitotikus képletekhez köthetőek, úgymint a centroszóma, a centroméra, a kinetokór, a mitotikus orsó mikrotubulusai vagy akár az ún. orsó összeszerelődést ellenőrző rendszer (Spindle Assembly Checkpoint (SAC)) szabályozásában szerepet játszó fehérjekomplexek alkotói.

Természetesen a tömegspektrometriai analízis során azonosított fehérjék nem mindegyike valós fizikai interakciós partnere az EVH1 vagy Smk-1 doméneknek, hiszen olyan fehérjéket is sikerült azonosítani, melyek többalegységes fehérje komplexumok részei (pl. a teljes CPC (Chromosome Passenger Complex) komplexet azonosítottuk, amely az INCENP, AuroraB kináz, Borealin és Deterin fehérjékből áll). Ez azt sugallja, hogy az interakció egy fehérje komplexum egyik alegysége és az EVH1 között erős. A további kísérletek során vizsgálandó fehérjék kiválasztásához elsőként a 
tömegspektrometriában hatásfokot kifejező, magas ún. Mascot-score-al és nagy peptid számmal jelenlévőket szelektáltuk ki, majd in vitro kötési kísérletek segítségével vizsgáltuk meg a Flfl (és doménjei) tényleges interakciós partnereit.

\begin{tabular}{|c|c|c|c|c|c|c|c|c|c|}
\hline \multirow[b]{2}{*}{ Név } & \multicolumn{2}{|c|}{ GST-EVH1 } & \multicolumn{2}{|c|}{ GST-Smk-1 } & \multirow[b]{2}{*}{ Név } & \multicolumn{2}{|c|}{ GST-EVH1 } & \multicolumn{2}{|c|}{ GST-Smk-1 } \\
\hline & Score & \# pep & Score & \# pep & & Score & \# pep & Score & \# pep \\
\hline hyperplastic discs & 1804 & 33 & 184 & 3 & Spd2 & 88 & 2 & - & - \\
\hline Prp16 & 1540 & 29 & - & - & early girl & 84 & 1 & - & - \\
\hline Miranda & 1021 & 17 & - & - & Shroom & 70 & 1 & - & - \\
\hline CG8478 & 1001 & 16 & 161 & 2 & Grip75 & 40 & 1 & 62 & 1 \\
\hline PsC & 942 & 17 & - & - & Ana1 & 30 & 1 & - & - \\
\hline staufen & 396 & 5 & - & - & Dhc 64C & - & - & 299 & 6 \\
\hline Cenp-C & 396 & 8 & - & - & Drp1 & - & - & 298 & 5 \\
\hline Aurora B & 367 & 6 & - & - & Nipsnap & - & - & 286 & 5 \\
\hline Borealin-related & 337 & 7 & - & - & Rod & - & - & 172 & 3 \\
\hline fascetto & 313 & 6 & - & - & Ras 85D & - & - & 155 & 2 \\
\hline coilin & 300 & 5 & - & - & Otefin & - & - & 142 & 1 \\
\hline INCENP & 297 & 4 & - & - & Rfc4 & - & - & 122 & 1 \\
\hline NuMA & 285 & 5 & - & - & licorne & - & - & 99 & 2 \\
\hline Sex combs extra & 283 & 4 & - & - & ZW10 & - & - & 90 & 1 \\
\hline Deterin (Survivin) & 238 & 3 & - & - & spindle A & - & - & 75 & 1 \\
\hline stonewall & 237 & 5 & - & - & PCNA & - & - & 72 & 1 \\
\hline sosondowah & 179 & 3 & - & - & asp & - & - & 54 & 2 \\
\hline Centrobin & 168 & 3 & - & - & Elongin B & - & - & 54 & 1 \\
\hline Aurora A & 134 & 2 & - & - & Zwilch & - & - & 49 & 1 \\
\hline pebble & 106 & 1 & - & - & BAF & 238 & 3 & 70 & 2 \\
\hline
\end{tabular}

2. táblázat. Az AP-MS eredmények alapján további vizsgálatokra kiválasztott fehérjék. A nyers tömegspektrometriai eredmények közül a Mascot-score és peptidszám (\# pep) alapján választottuk ki azokat a fehérjéket, melyek esetében az in vitro kötési kísérletek elvégzése érdemes lehet. A GST-EVH1 a Flfl 1-168 aminosav, míg a GST-Smk-1 a Flfl 169-361 aminosav szakasza.

\subsection{A Flfl valós fizikai interakciós partnereinek meghatározása in vitro kötési kísérletekkel}

Annak meghatározásához, hogy a kiválasztott lehetséges interakciós partnerek közül melyek azok, melyek valóban fizikai kölcsönhatásba lépnek a Flfl EVH1 vagy Smk-1 doménjeivel, in vitro kötési kísérleteket végeztünk. Ehhez próba fehérjeként E. coli-ban termeltetett és Glutathione sepharose 4B gyöngyökhöz immobilizált rekombináns GST-EVH1 és GST-Smk-1 fehérjéket használtunk (6. ábra). Negatív kontrollnak gyöngyökhöz immobilizált GST-t alkalmaztunk.

A vizsgálni kívánt fehérjéket kapcsolt in vitro transzkripciós és transzlációs (IVTT) rendszerben termeltettük cDNS-ről vagy PCR-rel előállított lineáris DNS-ről. Az 
IVTT során a fehérjéket ${ }^{35} \mathrm{~S}$-metioninnal jelöltük, a kötési kísérletek eredményét autoradiográfiával detektáltuk (6. ábra).

A vizsgálandó fehérjéink kódoló cDNS-ét a Drosophila Gold Collection plazmid könyvtárából [162] használtuk. A kollekcióban megtalálható plazmidok közül a pOT2 és a pFlc-1 tartalmaz T7 promotert, ezért ezek alkalmasak az általunk használt T7 promoter vezérelt IVTT rendszerben történő fehérje termeltetésre. A pOTB7 és pBS SKplazmidokban lévő cDNS-eket szubklónoztuk az IVTT rendszerre optimalizált pHY22 [157] vektorba restrikciós emésztés és DNS ligálás segítségével. Mivel a pFlc-1 vektorban lévő fehérjék nem termelődtek megfelelően, ezért ezeket a géneket szintén pHY22-be klónoztuk. Némely fehérje esetében nem működött a plazmidról történő termeltetés, ezért ezekről a cDNS-ekről egy T7 promotert hordozó lineáris DNS-t hoztunk létre PCR segítségével, majd ezt használtuk az IVTT reakciókban templátként.
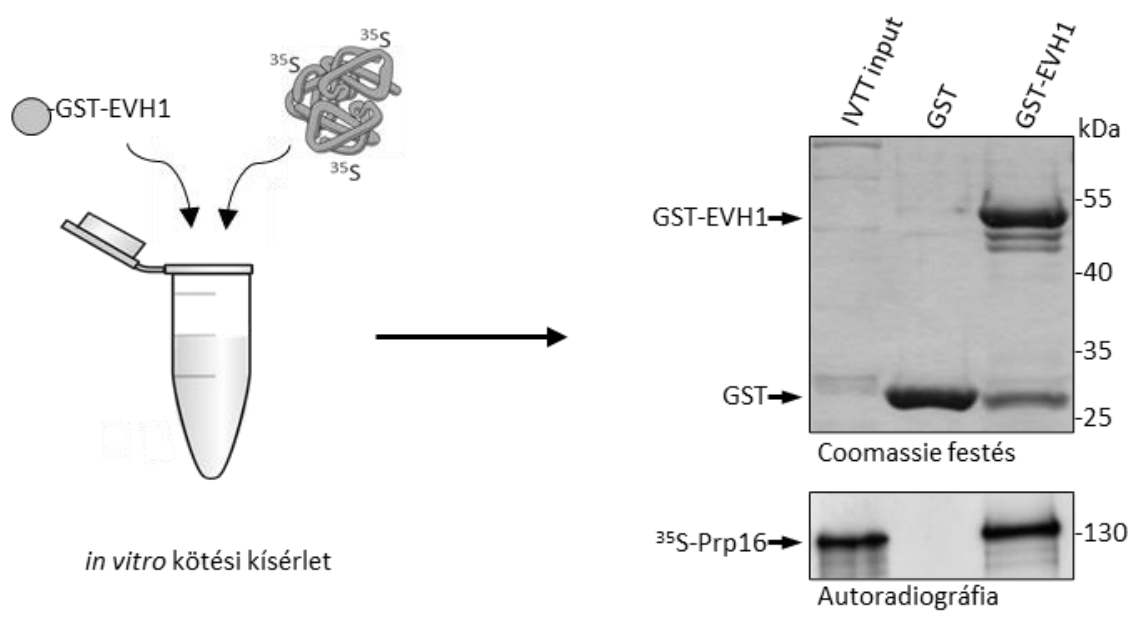

6. ábra. Példa az in vitro kötési kísérletre és eredményének detektálására. A kötési kísérlet során a gyöngyökön immobilizált próba és az in vitro termeltetett, radioaktív metioninnal jelölt, vizsgálni kívánt fehérjéket együtt inkubáltuk, majd több mosási lépés után a fehérjéket SDS-PAGE-el szeparáltuk. A Coomassie BB festés segítségével meggyőződhetünk arról, hogy a mosások során nem veszítettünk a gyöngyökböl, illetve, hogy a próba és a negatív kontroll fehérjékből összemérhető mennyiséget használtunk. A gél szárítása után az interakciók meglétét vagy hiányát az izotóp gyenge sugárzására érzékeny röntgenfilmmel detektálhatjuk. Az ábrán jól látható, hogy a Prp16 erős, specifikus interakcióba lép a Flfl EVH1 doménjével.

Az in vitro kötési kísérletekkel 15 fehérjét sikerült azonosítanunk, mint Flfl/PP4 kölcsönható partnerek. Ezen fehérjék közül 8 a Flfl EVH1 doménjével, míg 8 a Flfl 
Smk-1 doménjével lép specifikus interakcióba (7. ábra és 3. táblázat). Érdekes, hogy míg az EVH1-al kölcsönható fehérjék esetében kivétel nélkül erős kötést tapasztaltunk, az Smk-1 az esetek többségében egy sokkal gyengébb, habár fajlagos, kölcsönhatást alakított ki az interakciós partnereivel (7.ábra). Ennek okát egyelöre nem sikerült tisztáznunk.
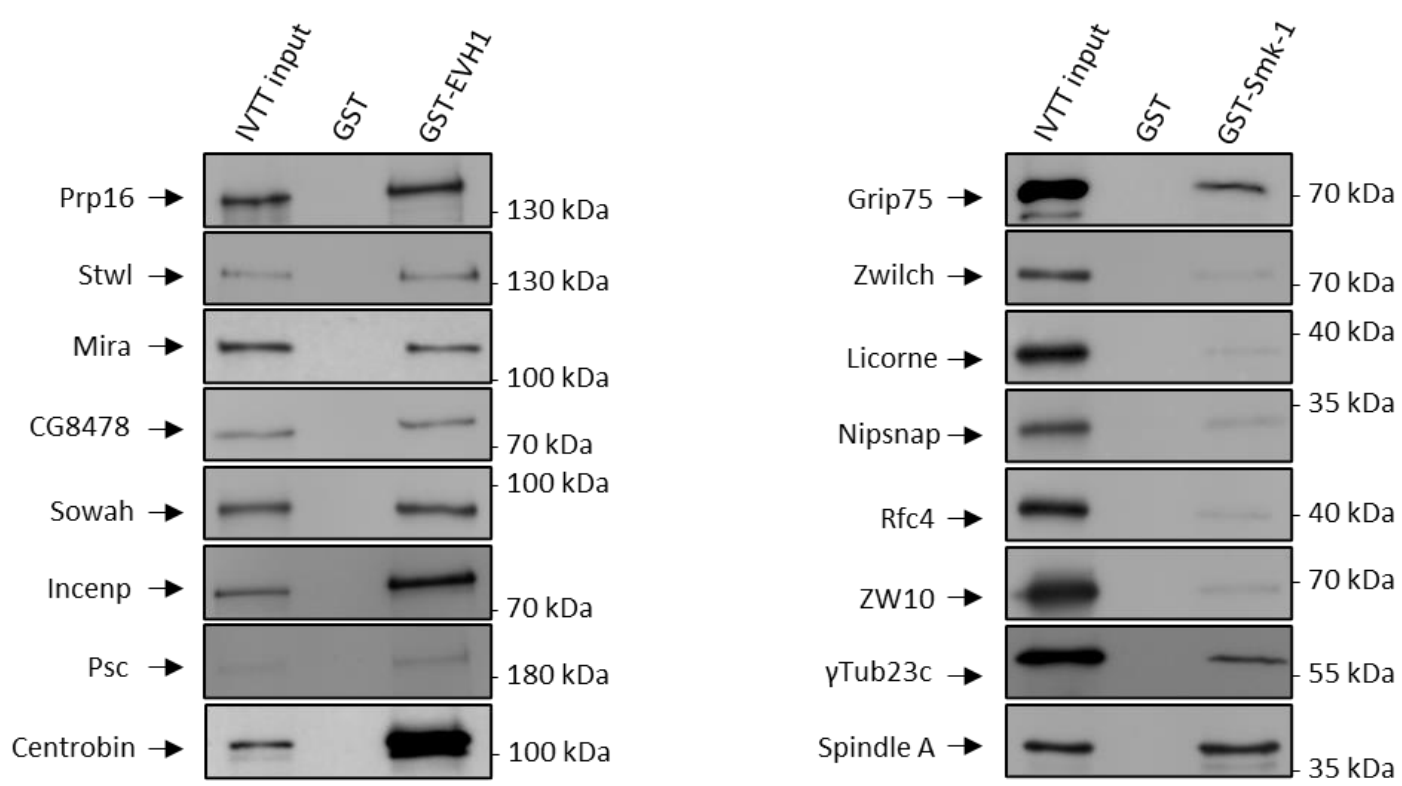

7. ábra. Az EVH1 és Smk-1 domének újonnan azonosított közvetlen kölcsönható partnerei. Az in vitro kötési kísérletek segítségével a Flfl-nek hét új EVH1 doménen keresztül kötődő fizikai interakciós partnerét és nyolc új, az Smk-1 doménen keresztül megkötött partnerét azonosítottuk. Míg az EVH1 esetében az összes fehérjével egy erős, specifikus interakciót mutattunk ki, addig az Smk-1 esetében a kölcsönhatások több esetben is gyengébbnek tüntek. A Mira már egy korábban igazolt EVH1 interakciós partner [44], melyet a mi eredményeink is megerősítenek. 


\begin{tabular}{|l|c|c|l|}
\hline \multicolumn{1}{|c|}{ fehérje } & CG szám & kölcsönható domén & \multicolumn{1}{|c|}{ lokalizáció és funkció } \\
\hline Incenp & CG12165 & EVH1 & CPC alegység, sejtosztódás különböző folyamatainak szabályozása \\
\hline Prp16 & GG32604 & EVH1 & spilceoszóma, mRNS érés \\
\hline Sowah & CG10632 & EVH1 & nincs adat \\
\hline Centrobin & CG5690 & EVH1 & leány cetriólum, mikrotubulus organizáció \\
\hline Psc & CG3886 & EVH1 & polycomb fehérje, homeotikus gének szabályozása \\
\hline Stwl & CG3836 & EVH1 & heterokromatin, őssejt populáció fenntartása \\
\hline CG8478 & CG8478 & EVH1 & RNS polimeráz II-n keresztüli transzkripciós reguláció (feltételezett) \\
\hline Miranda & CG12249 & EVH1 & citoplazma, neuroblasztok aszimmetrikus osztódása \\
\hline Licorne & CG12244 & Smk-1 & citoplazma, Ser/Thr kináz \\
\hline Nipsnap & CG9212 & Smk-1 & mitokondrium (feltételezett) \\
\hline RfC4 & CG14999 & Smk-1 & sejtmag, DNS replikáció és DNS hibajavitás \\
\hline ZW10 & CG9900 & Smk-1 & RZZ alegység, kinetokór, Spindle Assembly Checkpoint \\
\hline Zwilch & CG18729 & Smk-1 & RZZ alegység, kinetokór, Spindle Assembly Checkpoint \\
\hline Spindle A & CG7948 & Smk-1 & DNS rekombináció, DSB hibajavitás \\
\hline YTub23C & CG3157 & Smk-1 & citoplazma, mikrotubulus citoszkeleton szervezése \\
\hline Grip75 & CG6176 & Smk-1 & centroszóma, mikrotubulus nukleáció, ivarsejt képzés és mitózis \\
\hline
\end{tabular}

3. táblázat. Az újonnan igazolt Flfl-lel kölcsönható fehérjék sejten belüli lokalizációja és legfontosabb funkciói. Az egyes fehérjék lokalizációjával és legfontosabb funkcióival kapcsolatos adatokat a FlyBase adatbázisából gyüjtöttük össze.

\subsection{Az interakciós felületek térképezése}

Mivel az EVH1 domén szerepe ismert a szubsztrátum kötésben, ezért ezen domén konszenzus szubsztrátum felismerési motívumának meghatározásához első lépésként elkezdtük meghatározni a lehető legrövidebb interakciós felületeket. Ha tudjuk, hogy az egyes fehérjéinknek melyek azok a rövid aminosav régiói, amelyek szükségesek az interakció kialakulásához, akkor sokkal nagyobb hatékonysággal tudunk egy motívum keresésébe kezdeni, mintha ugyanezt a teljes hosszúságú fehérjék esetében kísérelnénk meg. Mivel az Smk-1 domén funkciójáról semmit nem tudunk, de mégis több fehérjével is specifikus interakciót mutat (7. ábra), ezért az EVH1-hez hasonlóan itt is elkezdtük az interakciós felületek meghatározását.

A PP4 szubsztrátum-felismerési motívumának azonosításához elkezdtük a Flfl doménekhez kötődő, újonnan azonosított fehérjék Flfl-lel kölcsönható felületeinek behatárolását. Ehhez az egyes fehérjékből kisebb, átfedő darabokat generáltunk PCR termékekről IVTT rendszerben, majd ezekkel a polipeptidekkel is elvégeztük az in vitro kötési kísérleteket. Az átfedő darabok létrehozása során igyekeztünk elkerülni, hogy a fontos másodlagos szerkezeti elemeket károsítsuk, ezért in silico predikciós programmal (Jpred [163]) meghatároztuk a másodlagos szerkezeti elemek valószínü határait. Az interakciós felületek térképezésének menetét a Prp16 példáján keresztül a 8. ábra 
szemlélteti. Első körben a fehérjéket három átfedő, közel azonos méretű szakaszra bontottuk (4. táblázat).

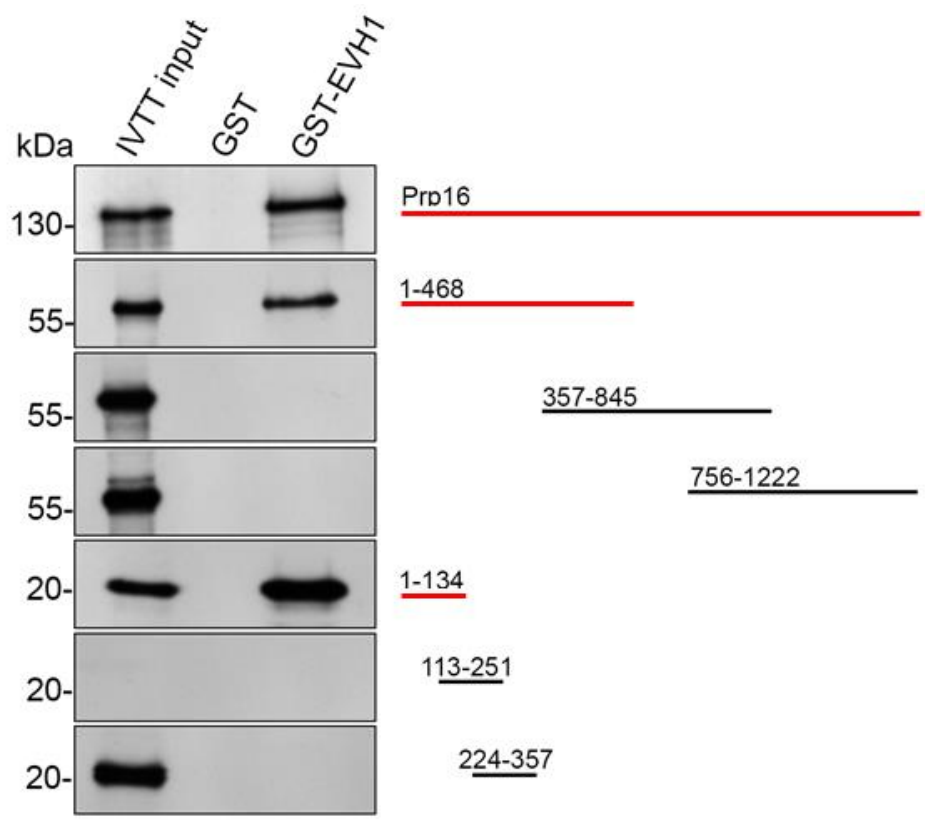

8. ábra. Az interakciós felületek térképezésének menete. Az EVH1 vagy Smk-1 doménnel interakcióba lépő teljes hosszúságú fehérjéket először három, egymással átfedő szakaszra bontottuk (Prp16 esetében ez 1-468, 357-845 és 756-1222 aminosavak). Az ezekkel a szakaszokkal elvégzett in vitro kötési kísérletek alapján azt a régiót, amely interakcióba lépett (ez esetben az 1-468 aminosav szakasz) további rövidebb szakaszokra bontva vizsgáltuk. A Prp16 113-251 aminosavas szakaszának példáján keresztül jól látható, hogy az általunk használt IVTT rendszer korlátozott, a kisebb méretü fehérjék termelése nem minden esetben sikeres ezzel a módszerrel. 


\begin{tabular}{|c|c|c|c|c|c|}
\hline fehérje & szakasz & EVH1 kötés & fehérje & szakasz & Smk-1 kötés \\
\hline \multirow{3}{*}{ Incenp } & $1-329$ & - & \multirow{3}{*}{ ZW10 } & $1-187$ & - \\
\hline & $223-534$ & - & & $144-337$ & + \\
\hline & $445-755$ & + & & 294-485 & - \\
\hline \multirow{3}{*}{ Psc } & $1-594$ & - & \multirow{3}{*}{$\mathrm{RfC} 4$} & $1-126$ & n.a. \\
\hline & 505-1098 & + & & $101-226$ & + \\
\hline & $1009-1601$ & - & & $206-331$ & - \\
\hline \multirow{3}{*}{ Sowah } & $1-276$ & - & \multirow{3}{*}{ Licorne } & $1-132$ & + \\
\hline & $183-474$ & - & & $102-233$ & - \\
\hline & $357-635$ & + & & 204-334 & - \\
\hline \multirow{3}{*}{ Prp16 } & $1-468$ & + & \multirow{3}{*}{ Nipsnap } & $1-100$ & n.a. \\
\hline & $357-845$ & - & & 79-194 & + \\
\hline & $756-1222$ & - & & $172-273$ & - \\
\hline \multirow{3}{*}{ CG8478 } & $1-250$ & - & \multirow{3}{*}{ Grip75 } & $1-100$ & - \\
\hline & $162-411$ & - & & 91-190 & - \\
\hline & $323-571$ & - & & $181-280$ & + \\
\hline \multirow{6}{*}{ Stwl } & $1-243$ & - & \multirow{3}{*}{ Spindle A } & $1-120$ & - \\
\hline & $1-393$ & - & & $109-228$ & + \\
\hline & $1-510$ & - & & $217-336$ & + \\
\hline & $1-730$ & + & \multirow{3}{*}{ Zwilch } & $1-220$ & + \\
\hline & $750-1037$ & + & & $218-431$ & - \\
\hline & & & & $422-641$ & + \\
\hline
\end{tabular}

4. táblázat. Az EVH1 és Smk-1 doménekkel kölcsönható fehérjék interakciós felületei. Az egyes fehérjék vizsgált darabjai és az interakció létrejötte (+) vagy hiánya (-) az EVH1 és az Smk-1 doménekkel. Két esetben nem sikerült IVTT reakcióval a kívánt szakaszt megtermeltetni, így ezek kötődését nem tudtuk meghatározni (n.a.). Az adatok alapjául szolgáló autoradiográfiás eredmények a 9. és 10. ábrán láthatóak.

Az EVH1-hez kötődő interakciós partnerek közül az Incenp, Psc, Sowah és Prp16 esetében sikerült egyértelmüen a fehérjék azon egyharmadát meghatároznunk (9. ábra), amely az interakció kialakításához szükséges. A CG8478 esetében a fehérje egyik szakaszánál sem tudtunk interakciót detektálni (9. ábra), míg a Stwl esetében két, nem átfedő fragmens is interakciót mutatott (9. ábra). Előbbire magyarázat lehet, hogy a fehérje egy rövidebb aminosav szekvenciája esetében nem alakul ki a megfelelö térszerkezet, ezért nem jön létre a kötőhely, míg az utóbbi esetben vagy két különböző, de azonos affinitású kötőhely lehet, vagy az egyik régió aspecifikus interakciót alakít ki. 

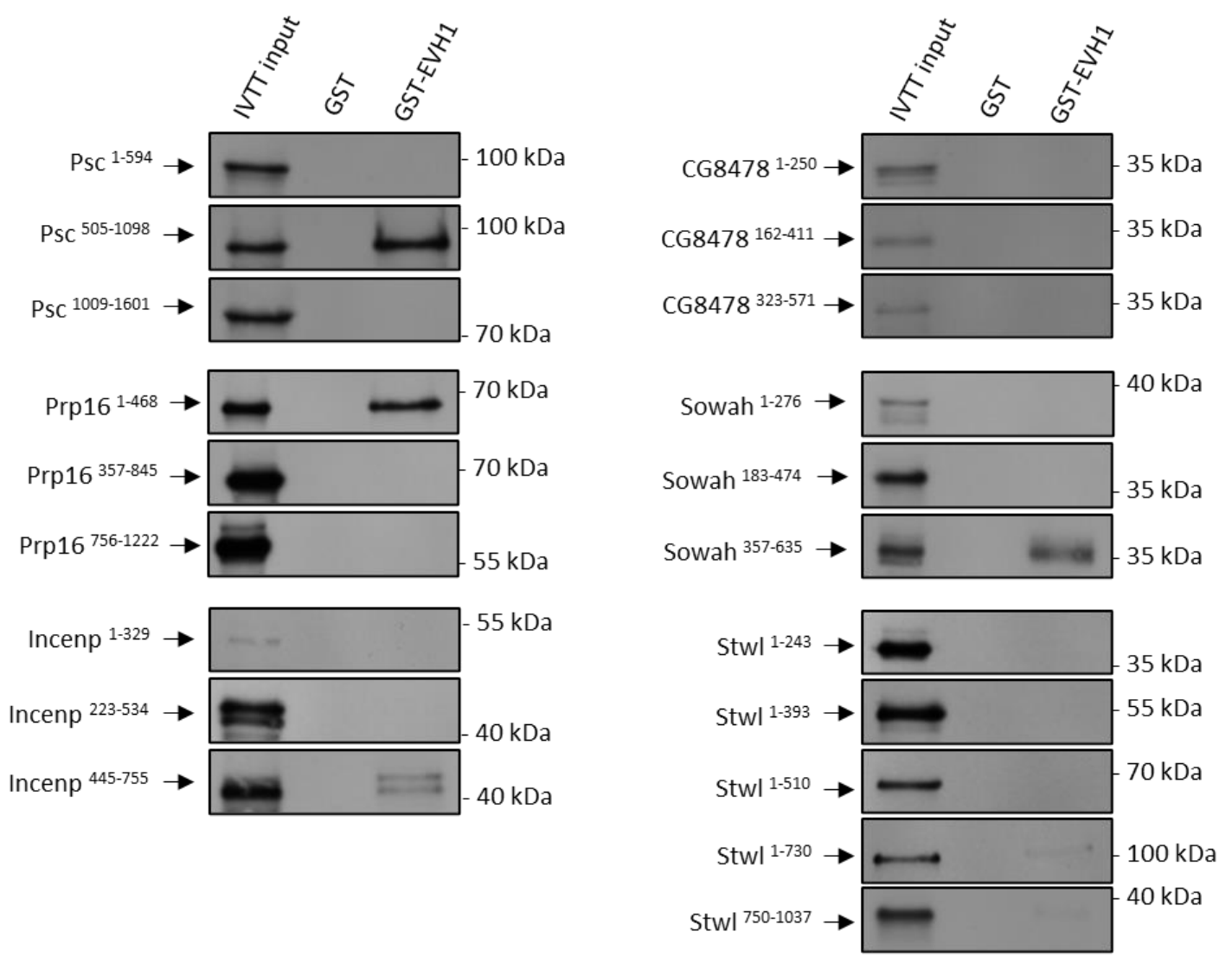

9. ábra. Az EVH1 doménnel kölcsönható fehérjék interakciós felületeinek térképezése. A Stwl és CG8478 fehérjék kivételével a többi esetben sikerült meghatároztuk a fehérjék azon harmadát, amely az interakció kialakításáért felelős szakaszt tartalmazza. A Stwl esetében mind az 1-730, mind a 750-1037 szakasz esetén detektáltunk egy gyenge interakciót, ami alapján nem dönthető el egyértelmüen, hogy a fehérjének mely rövidebb szakasza kötődik az EVH1 doménhez. A CG8478 esetében a vizsgált szakaszok közül egyik sem kötődött a próba fehérjéhez. Az in vitro kötési kísérletek során a negatív kontroll GST volt.

Az Smk-1-gyel kölcsönható partnerek közül a ZW10, Grip75, Licorne, Nipsnap és Rfc4 fehérjék esetén egyértelmüen sikerült azonosítanunk a fehérjék interakcióért felelős harmadát (10. ábra). Az Rfc4 és Nipsnap esetében a fehérjék első részeit (1-126 és 1-100 aminosav szakasz) nem sikerült IVTT reakcióval megtermeltetni (10. ábra), így ezekről nincsenek adataink, de az eredmények ezek nélkül is értelmezhetőek. A Spindle A esetében a 2. és 3. szakasz is interakcióba lépett az Smk-1-gyel (10. ábra), a kötődésért felelős szakasz nagy valószínüséggel ezen darabok átfedő részén helyezkedhet el. A Zwilch esetében azt tapasztaltuk, hogy a fehérje 1. és a 3. része is kötődik a Smk-1-hez (10. ábra), ami az EVH1 és Stwl esetéhez hasonlóan (9. ábra) két különböző kötőhelyet, vagy az egyik rész aspecifikus kötődését is jelentheti. 

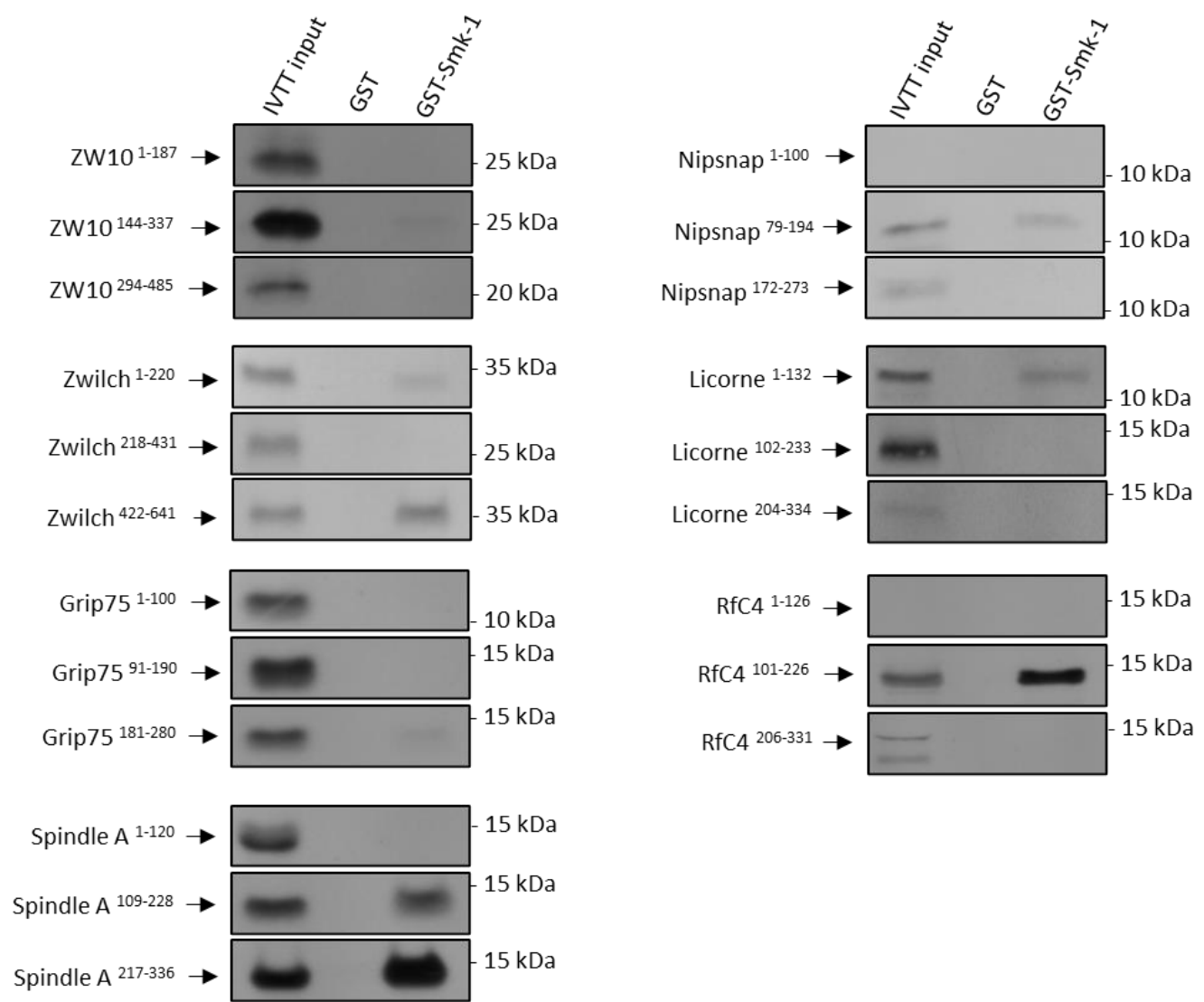

10. ábra. Az Smk-1 doménnel kölcsönható fehérjék interakciós felületeinek térképezése. Minden fehérje esetében sikerült az interakciós felületet behatárolni a fehérje egyharmadára, kivéve a Zwilch esetében, ahol az első és harmadik szakasz interakciója miatt az eredmények több módon is értékelhetőek. Az Rfc4 és Nipsnap esetében nem müködött az IVTT reakció a fehérjék első fragmense esetén. Az in vitro kötési kísérletek során a negatív kontroll GST volt.

A fent leírt kísérleteinkkel meghatároztuk az EVH1 és Smk-1 doménekkel kölcsönható fehérjék rövidebb szakaszait. Azon interakciós partnerek esetén, melyeket még további kisebb darabokra bonthattuk anélkül, hogy átlépnénk az IVTT rendszer 90-100 aminosavas fehérjét legtöbb esetben stabilan megtermelni képes alsó mérethatárát, folytattuk az interakciós felületek meghatározását. Az 5. táblázatban összefoglaltuk a vizsgált szakaszok és a kötési kísérletek eredményeit. 


\begin{tabular}{|c|c|c|c|c|c|}
\hline fehérje & szakasz & EVH1 kötés & fehérje & szakasz & EVH1 kötés \\
\hline \multirow{5}{*}{ Psc } & 594-750 & - & \multirow{2}{*}{ Sowah } & $474-574$ & + \\
\hline & $721-876$ & + & & 537-635 & - \\
\hline & $847-876$ & - & fehérje & szakasz & Smk-1 kötés \\
\hline & $721-810$ & + & \multirow{2}{*}{ Nipsnap } & 70-159 & + \\
\hline & $786-875$ & + & & $121-210$ & + \\
\hline \multirow{3}{*}{ Prp16 } & $1-134$ & + & \multirow{3}{*}{ Zwilch } & $422-504$ & - \\
\hline & $113-251$ & n.a. & & $491-573$ & - \\
\hline & $224-357$ & - & & $560-641$ & + \\
\hline \multirow{2}{*}{ CG8478 } & $1-411$ & - & \multirow{2}{*}{ Licorne } & $1-85$ & - \\
\hline & $162-571$ & + & & $66-150$ & + \\
\hline \multirow{3}{*}{ Incenp } & 534-634 & - & \multirow{3}{*}{ Rfc4 } & $101-180$ & + \\
\hline & 600-699 & - & & $120-226$ & + \\
\hline & $657-755$ & - & & $147-226$ & - \\
\hline
\end{tabular}

5. táblázat. Az EVH1 és Smk-1 doménekkel kölcsönható fehérjék interakciós felületeinek térképezése II. Az egyes fehérjék kötés szempontjából vizsgált fragmentumainak kiterjedése és az interakció létrejötte (+) vagy hiánya (-) az EVH1 és az Smk-1 doménekkel. A Prp16 113-251 fragmentumát nem sikerült az IVTT reakcióval megtermeltetnünk, így erről nem rendelkezünk kísérletes adattal (n.a.). Az adatok alapjául szolgáló autoradiográfia eredmények a 11. ábrán láthatóak. 

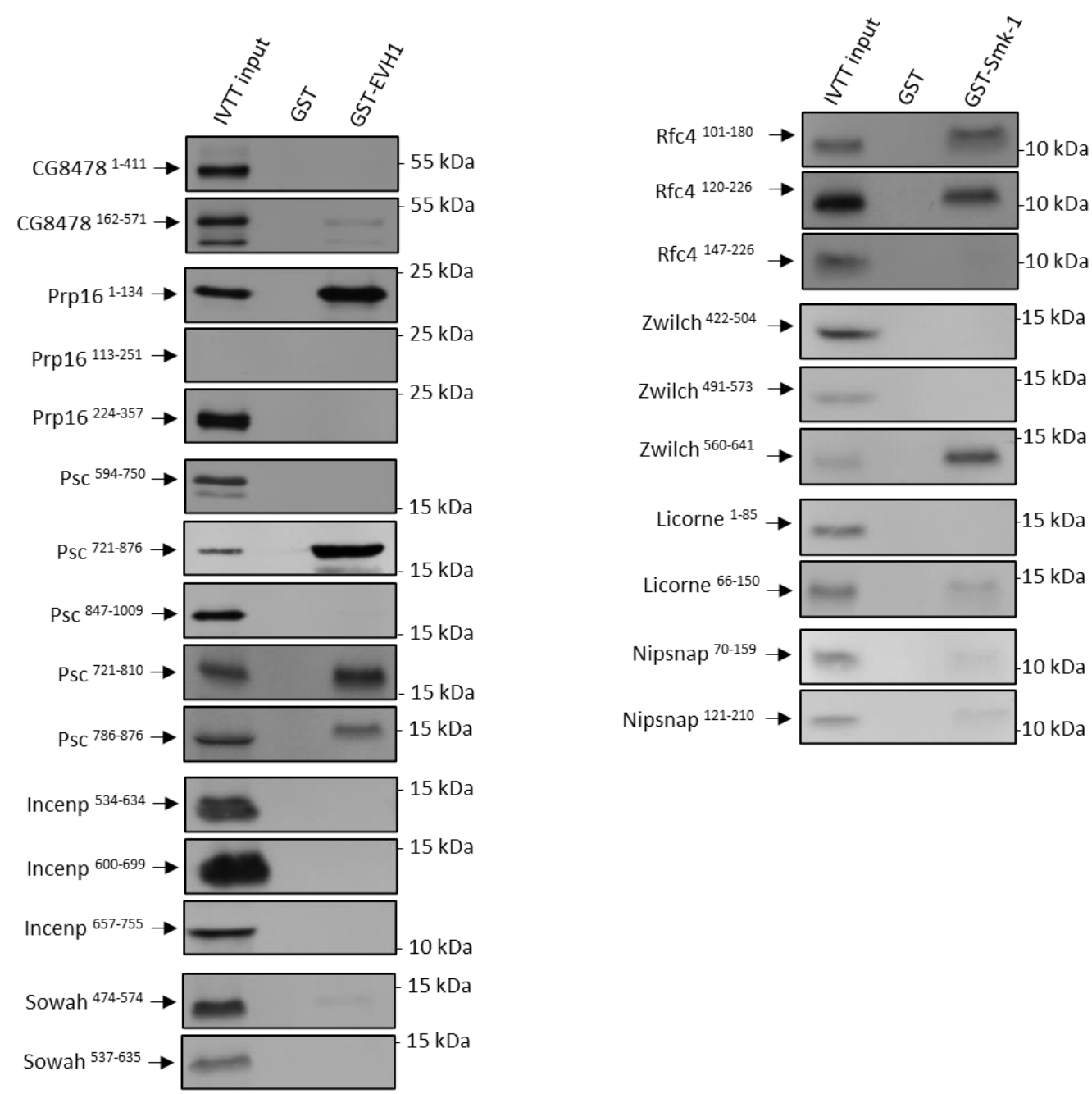

11. ábra. Az EVH1 és Smk-1 doménekkel kölcsönható fehérjék interakciós felületeinek meghatározása. A Prp16, Psc és Sowah fehérjék esetében sikerült meghatároznunk egy 140 aminosavnál rövidebb, az EVH1 doménhez való kötésért felelős szakaszt. A CG8478 esetében a kötésért felelős fragmentum valószínüleg a fehérje C-terminális részén található. Az Incenp esetén az interakciós felület további behatárolása sikertelen volt. Az Smk-1 domén kölcsönható partnerei közül a ZW10 kivételével sikerült egy 100 aminosavnál rövidebb szakaszra behatárolnunk az interakcióért felelős részt.

Amikor a CG8478 fehérjét három részre bontottuk (9. ábra), akkor egyik szakasz sem lépett kölcsönhatásba az EVH1 doménnel, azonban a fehérje első és utolsó kétharmadának kötési kísérletéből jól látható (11. ábra), hogy az interakcióért felelős szakasz nagy valószínüséggel a fehérje C-terminálisának közelében helyezkedik el. Az Incenp esetében az interakciós felület behatárolását célzó további kísérleteink sikertelenek voltak (11. ábra). A Prp16, Psc és Sowah esetében az interakciós felületeket sikerült kellöképpen behatárolni (11. ábra). Az Smk-1 domén kölcsönható partnerei közül az Rfc4, Zwilch, Licorne és Nipsnap esetén voltak sikeresek a kísérletek (11. ábra). Az egyes fehérjék legrövidebb interakciós felületeit a 6. táblázat foglalja össze. 


\begin{tabular}{|l|c||l|c|}
\hline fehérje & szakasz (as) & fehérje & szakasz (as) \\
\hline Prp16 & $1-134$ & Spindle A & $217-228$ \\
\hline Psc & $721-876$ & Nipsnap & $121-159$ \\
\hline Incenp & $445-755$ & Zwilch & $560-641$ \\
\hline Stwl & $511-1037$ & Licorne & $86-150$ \\
\hline Sowah & $474-574$ & Rfc4 & $101-120$ \\
\hline CG8478 & $411-571$ & ZW10 & $144-337$ \\
\hline \multicolumn{1}{|l}{} & Grip75 & $190-280$ \\
\end{tabular}

6. táblázat. Az EVH1 és Smk-1 doménekhez kötődő fehérjék in vitro kötési kísérletek segítségével meghatározott interakciós felületei.

\subsection{A konzervált EVH1 felismerési motívum azonosítása és a kötőhelyek meghatározása}

Az EVH1 konzervált szubsztrátum-felismerési motívumának azonosításához a rendelkezésre álló feltérképezett interakciós felületek mellett a témavezetőm által publikált korábbi eredményekből indultunk ki [48]. Még 2015-ben kimutatták, hogy a CENP-C fehérje megkötéséért és ez által a PP4 foszfatáz centromérához való kötődéséért a Flfl EVH1 doménje a felelős. Ezen kívül meghatározták a CENP-C-nek azt a minimális, 19 aminosav hosszú szakaszát (Falafel interacting motif, FIM, 1048-PDESSADVVFKKPLAPAPR-1066), ami feltétlen szükséges az interakcióhoz. Ezen belül is kritikus szerepet játszik a szakasz közepén elhelyezkedő fenil-alanin-lizinlizin-prolin (FKKP) aminosav motívum, ugyanis az első pozícióban lévő $\mathrm{F}$ és a negyedik pozícióban lévő $\mathrm{P}$ aminosavak nélkülözhetetlenek az interakció szempontjából [48]. Röntgenkrisztallográfiai módszerrel igazolták, hogy a Falafel EVH1 doménje nem kanonikus, emiatt nemcsak az EVH1-ekre jellemző poliprolin ligandumokat képes megkötni, hanem a FIM-et is [48]. Ez azt feltételezi, hogy a Falafel és más R3 ortológok EVH1 doménje egy új csoportot képez az EVH1 domének családjában, ahová a kanonikus EVH1 domének is tartoznak. Feltételezésünk szerint ez az EVH1 típus a PP4 foszfatáz szubsztrátum-felismerésében konzervált mechanizmus alapján vesz részt.

A szakirodalmi adatok alapján kísérletesen csak egyetlen másik Drosophila fehérje (Miranda) esetében igazolt a Flfl EVH1 doménjével történő fizikai kölcsönhatás [44]. Megvizsgáltuk, hogy ebben a fehérjében található-e a CENP-C FKKP motívumához 
hasonló szekvencia. A Mirandában két nagyon hasonló motívumot is találtunk (FAIP, 7780 aminosavak és FRTP, 92-95 aminosavak), mindkettő az EVH1-al interakcióba lépő szakaszon helyezkedik el [44].

Az újonnan azonosított EVH1-hez kötődő fehérjék mindegyikében egy vagy több, a CENP-C FKKP, illetve a Miranda FAIP és FRTP szekvenciáihoz hasonló FxxP motívum is található (kivéve a CG8478-at), ezért valószínünek látszott, hogy ez a motívum lehet a PP4 számára a konzervált, rövid lineáris szubsztrátum felismerési szekvencia (SLiM).

2019 végén egy dán csoport azonosította a humán PP4R3 EVH1 doménjének szubsztrátum felismerési motívumát. Eredményeik megerősítették az általunk muslicában találtakat, ami tovább erősíti azt a feltételezést, miszerint a PP4 szubsztrátumfelismerési mechanizmusa konzervált és az enzim jól definiálható módon kötődik a kölcsönható partnereihez, szubsztrátumaihoz. Ueki és kollégái azt találták, hogy az FxxP motívumon kívül egy MxPP motívum is lehet a PP4 felismerési helye [155]. Ez alapján újra ellenőriztük az általunk talált interakciós partnereket és valóban, az FxxP motívumok mellett találtunk legalább egy MxPP motívumot minden új EVH1 kölcsönható fehérje esetében. A CG8478 fehérje, amely bár nem tartalmaz FxxP motívumot, tartalmaz egyetlen MxPP motívumot.

Mivel az interakciós felületek behatárolása utáni szakaszokon még mindig több FxxP és MxPP motívum volt, ezért helyspecifikus mutagenezis segítségével az első és a negyedik pozícióban lévő $\mathrm{F}$ és $\mathrm{P}$, illetve $\mathrm{M}$ és $\mathrm{P}$ aminosavakat alaninokra (A) cseréltük, hogy megvizsgáljuk, hogyan változik a mutáns fehérjék kötődése az EVH1 doménhez.

Miután kiválasztottuk a vizsgálandó motívumokat, a mutagenezis során nem csak a fehérjék rövidebb szakaszaiban, hanem a teljes hosszúságú fehérjékben rontottuk el a SLiM-eket, majd az egyes mutánsokkal elvégeztük az in vitro kötési kísérleteket. A mutánsok vizsgálata során a vad típusú fehérjék kötési tesztjeit is újra elvégeztük, hiszen a kötés erősségének változása megbízhatóan csak egyazon kísérleten belül állapítható meg (12. ábra). Az eredményeink alapján kijelenthetjük, hogy minden fehérje esetében van egy olyan kiemelt FxxP vagy MxPP motívum, aminek módosítása az EVH1-al való kölcsönhatás nagymértékü gyengüléséhez vagy teljes eltünéséhez vezet (12.ábra). Érdekes, hogy míg egyes fehérjék esetén egy kiemelt motívum megváltoztatása az EVH1 doménnel kialakított kölcsönhatás teljes megszünéséhez vezet (12. ábra B), addig más fehérjék esetén az interakció megmarad, bár a kötési affinitás nagymértékben lecsökken (12. ábra A). Fontos megjegyezni, hogy míg a CENP-C FIM motívumában található 
FxxP-ben két lizin foglal helyet (FKKP), más, általunk és a fenti cikkben [155] azonosított PP4R3 EVH1 ligandumok esetében az xx aminosavak minden szabály nélkül, sokfélék lehetnek. Egyelöre nem sikerült rendszert találnunk az xx aminosavak milyenségében. Feltehetően az FxxP-n kívüli aminosavak és a fehérje szerkezetének tulajdonságai határozzák meg az xx identitását, fizikokémiai tulajdonságainak követelményeit. 

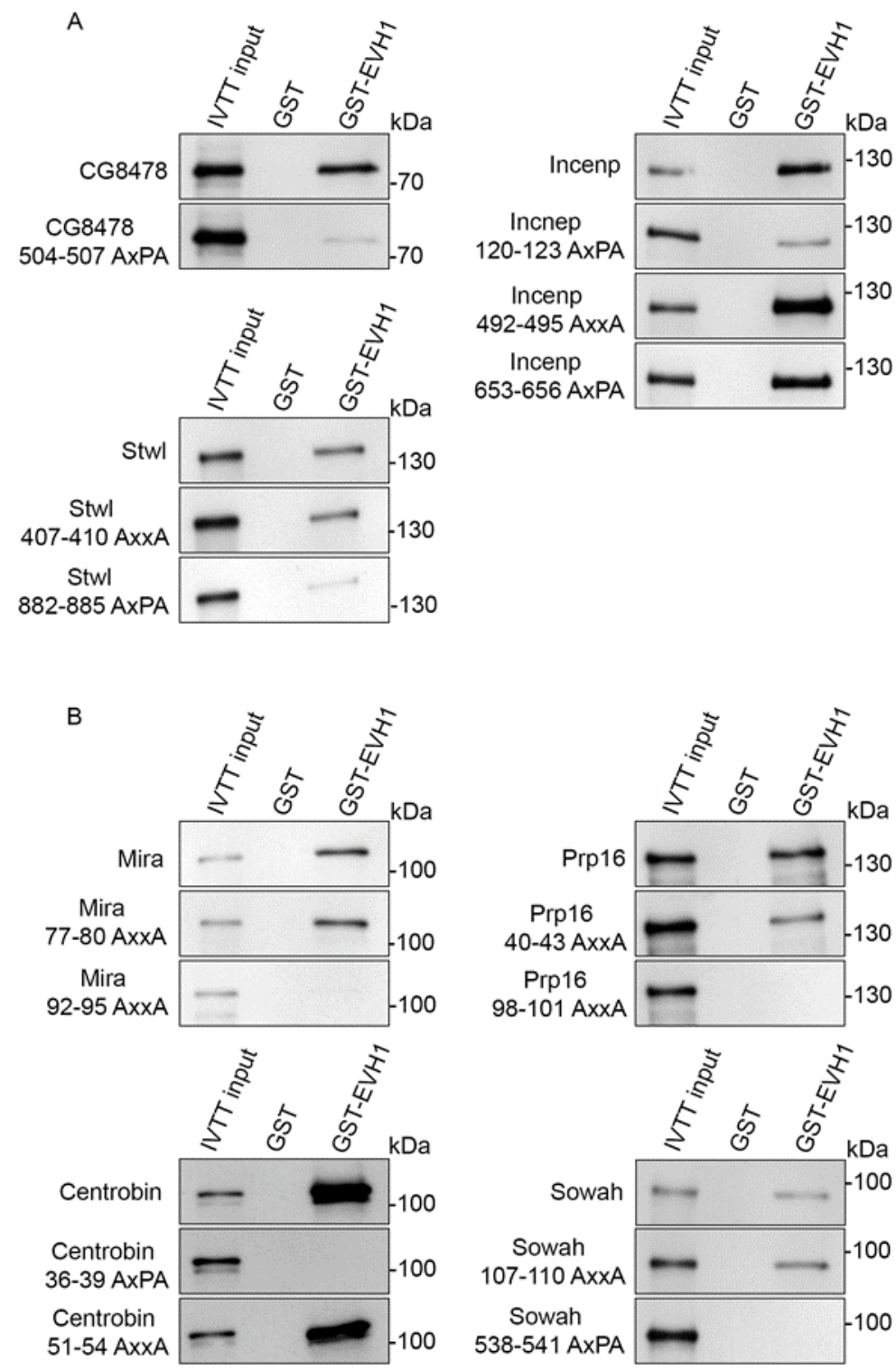

12. ábra. Az FxxP és MxPP motívumok mutációjának $(\operatorname{FxxP} \rightarrow \operatorname{AxxA}$ ill. $M x P P \rightarrow \operatorname{AxPA})$ hatása az EVH1-el történő interakcióra. Az általunk vizsgált fehérjéknél a legtöbb esetben (kivéve CG8478, ahol csak egyetlen MxPP motívum van a fehérjében) több lehetséges kötési motívumot is mutagenizáltunk az első és negyedik pozícióban lévő aminosavak alaninra való cseréjével. Az aminosav cserék hatását az EVH1-el való kölcsönhatásra in vitro kötési kísérletekkel vizsgáltuk. Három vizsgált fehérje esetében egy specifikus helyen lévő motívum elrontása az interakció nagymértékü legyengüléséhez vezetett, míg négy fehérje esetében ugyanez az interakció teljes mértékü megszünéséhez vezetett. Az autoradiográfiákhoz felhasznált gélek Coomassie festése bizonyítja, hogy az interakciók erősségének változása nem az eltérő mennyiségű próba fehérje következménye, a melléklet M1 és M2 ábráján látható. A 7. táblázatában összefoglaltuk a vizsgált motívumok \pm 20 aminosavas környezetét. 

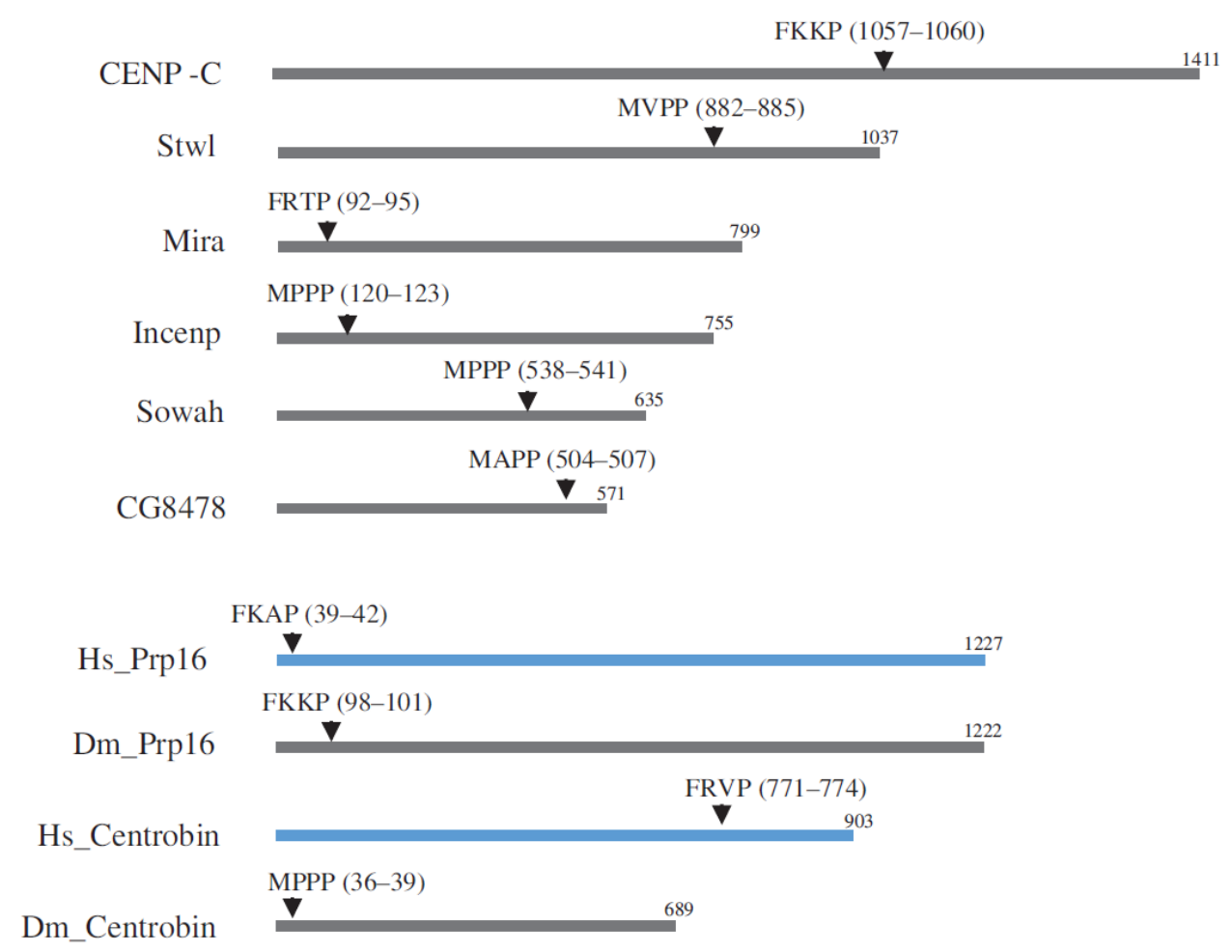

13. ábra. Az EVH1 kötésért felelős FxxP és MxPP motívumok. Az egyes EVH1 interakciós fehérjéknél (a Psc kivételével) sikeresen azonosítottuk az interakció kialakításához nélkülözhetetlen FxxP vagy MxPP motívumot. A Prp16 és Centrobin fehérjék esetében emberben (kék vonal, Hs_Prp16 és Hs_Centrobin) is ismertek a kötésért felelős motívumok [155].

\begin{tabular}{|c|c|c|l|}
\hline fehérje & motívum & $\begin{array}{c}\text { motívum pozíciója } \\
\text { (aminosav) }\end{array}$ & \multicolumn{1}{|c|}{ motívum \pm 20 aminosavas környezete } \\
\hline \multirow{3}{*}{ Incenp } & MPPP & $120-123$ & VSNSQLLAIAEDEHNSTASLMPPPPVPVSADTTLGSGRPQRAAK \\
\cline { 2 - 4 } & FFTP & $492-495$ & TPGSNNTPKIGKLPAPTVGRFFTPTQTTSTLPLSSAQPKKGPAS \\
\cline { 2 - 4 } & MLPP & $653-656$ & KFKELEQQKLQQLTGAKPKKMLPPPPKTKYTWEMLHEDDSTDDE \\
\hline \multirow{2}{*}{ Sowah } & FDSP & $107-110$ & AVAAASGIPEPSSPGGASLNFDSPMRQPPPYKPPPMVTSPPAVS \\
\cline { 2 - 4 } & MPPP & $538-541$ & DGVHKSWGSADNIPHRSEDLMPPPKAVEYISKRNKSSKRSSYAS \\
\hline \multirow{2}{*}{ Prp16 } & FKVP & $40-43$ & TRGGLVIRKPKDAGAGGGGGFKVPQGSMLGLDKLAAKRRAEKER \\
\cline { 2 - 4 } & FKKP & $98-101$ & TGGGSSTPQANASGASSEFAFKKPDTKSFEKLRGQLREHKDDTP \\
\hline \multirow{2}{*}{ CG8478 } & MAPP & $504-507$ & KPQQRISTIPKLAPSQGTQSMAPPSVKKIPKNVAHAGVYRTPTK \\
\hline \multirow{2}{*}{ Centrobin } & FAIP & $77-80$ & IEKFFKDAVRFASSSKEAKEFAIPKEDKKSKGLRLFRTPSLPQR \\
\cline { 2 - 4 } & FRTP & $92-95$ & KEAKEFAIPKEDKKSKGLRLFRTPSLPQRLRFRPTPSHTDTATG \\
\cline { 2 - 4 } & MPPP & $36-39$ & PPNFCAEDKMSACAAADALAMPPPPPPATTSAAYQFLHPSKKSE \\
\hline \multirow{2}{*}{ Stwl } & FPRP & $51-54$ & ADALAMPPPPPPATTSAAYQFLHPSKKSELNSINSRLQNIALDA \\
\cline { 2 - 4 } & MVPP & $882-885$ & NASAMEASMLKRRLIAAGHGMVPPTQRPRYSAVGASQMTTASQG \\
\hline
\end{tabular}

7. táblázat. Az in vitro vizsgált FxxP és MxPP motívumok és \pm 20 aminosavas környezetük. A kötésért felelős motívumok a táblázat második oszlopában vastag betűvel kiemeltek. 


\subsection{A Flfl 70. leucinjának szerepe a szubsztrátum kötésben}

Lipinszki és munkatársai röntgenkrisztallográfiás eredményeik alapján kimutatták, hogy a Flfl 70. pozíciójában (az EVH1 doménén belül) található leucin aminosav (L70) kiemelten fontos helyet foglal el a CENP-C FIM kötése során [48]. Rámutattak, hogy ez az aminosav valamennyi kanonikus EVH1 doménben mindig fenilalanin, ugyanakkor az összes PP4 R3 ortológban konzerváltan leucin. Ezért azt feltételeztük, hogy a 70-es leucin fontos szerepet játszik a Falafel/R3/SMEK1 EVH1 szubsztrátum-felismerő mechanizmusának kialakításában és az FxxP/MxPP SLiM-ek kötésében. Hogy a Flfl és kölcsönható partnerei közötti kapcsolatot ne csak a szubsztrátumok, hanem a Flfl részéröl is megvizsgálhassuk, helyspecifikus mutagenezissel létrehoztuk az EVH1 domén egy olyan mutánsát, amelyben a konzervált 70. leucint alaninra cseréltük $\left(E V H 1^{\mathrm{L} 70 \mathrm{~A}}\right)$. Ezt a mutánst N-terminálisan GST-hez fúzionálva baktériumokból tisztítottuk, majd a korábbiakban ismertetett módon in vitro kötési kísérletekhez használtuk. A korábban azonosított EVH1 interakciós fehérjék segítségével vizsgáltuk, hogy a mutáció milyen hatással van ezen fehérjék EVH1 doménhez való kötődésére. Azt tapasztaltuk, hogy a konzervált leucinnak a cseréje a korábban kimutatott erős interakciók teljes megszünéséhez vezet (14. ábra B), ami arra utal, hogy ez az aminosav valóban nélkülözhetetlen a Flfl EVH1 doménen keresztül történő fehérje-kötéshez. 


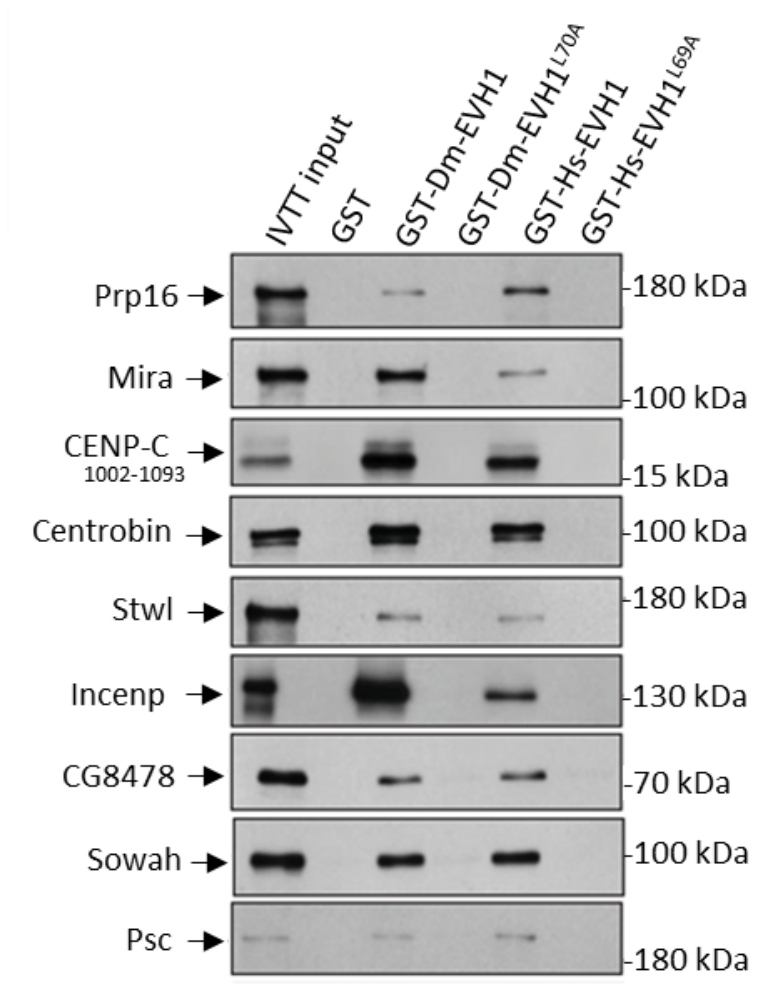

14. ábra. Az EVH1 interakciós fehérjék kötődése a vad típusú és mutáns, Drosophila és humán EVH1 doménekhez. A radioaktívan jelölt Drosophila fehérjéket in vitro termeltettük és in vitro kötési kísérlettel vizsgáltuk, hogy interakcióba lépnek-e az EVH1 domén változataival. Minden vizsgált fehérje esetében a Drosophila EVH1 ${ }^{\mathrm{L} 70 \mathrm{~A}}$ mutáció az interakció teljes megszünését eredményezte. Mivel a Drosophila Flf1 EVH1 és a humán SMEK1 EVH1 domének nagyfokú aminosavszekvencia-hasonlóságot mutatnak (A), és az EVH1 70. pozícióban lévő leucin is konzervált, ezért a vad típusú SMEK1 mellett a SMEK1 ${ }^{\text {L69A }}$ mutánssal is elvégeztük a kísérleteket. A humán SMEK1 EVH1 (Hs-EVH1) domén képes volt megkötni a vizsgált Drosophila fehérjéket is, a Hs-EVH1 ${ }^{\mathrm{L} 69 \mathrm{~A}}$ mutáns esetén pedig a Dm-EVH1 ${ }^{\mathrm{L} 70 \mathrm{~A}}$-hoz hasonlóan az interakció teljes eltünését tapasztaltuk. Negatív kontrollnak mindkét fehérje esetében GST-t használtunk.

A Drosophila Flfl EVH1 doménje nagyfokú szekvencia-homológiát mutat a humán R3/SMEK1 EVH1 doménjével (14. ábra A panel), és a Flfl-ben található konzervált leucin itt a 69. pozícióban található (L69). Kíváncsiak voltunk, hogy ezen leucin funkciója mennyire konzervált az egyes fajok között, ezért létrehoztuk a humán EVH1 doménnek is egy alanin szubsztitúciós mutánsát (Hs-EVH1 $\left.{ }^{\mathrm{L} 69 \mathrm{~A}}\right)$. A Drosophila 
fehérjékkel végzett kötési kísérletek alapján egyértelmü, hogy a 69-es leucin a humán SMEK1 esetében is nélkülözhetetlen a szubsztrátum kötéshez (14. ábra B). Ezek az eredmények azt bizonyítják, hogy a PP4 szubsztrátum felismerésében az EVH1 L70/L69-es leucin aminosava kritikus szerepet játszik, amely erősen konzervált a fajok között. Ezt támogatja az a tény is, miszerint a humán R3/SMEK1-ben található EVH1 képes megkötni a Falafel-kölcsönható partnereit is, melyek Drosophila fehérjék és nem feltétlenül találhatók meg emberben vagy nem mutatnak erős szekvencia homológiát a kritikus szakaszaikon.

\subsection{Az Smk-1 domén lehetséges szerepe a PP4 szubsztrátum kötésében}

Annak ellenére, hogy a Flfl Smk-1 doménje is nagyfokú konzerváltságot mutat az R3 ortológokban, a domén funkciójáról semmit sem tudunk. Az R3 alegységeken kívül egyetlen fehérjében mutatták ki (C.elegans Smk-1 fehérjéje, Ils longevity pathway alkotója [164]), de ott sem ismert a pontos biológiai szerepe vagy térszerkezete. Kísérleteink során a PP4 foszfatáz nyolc olyan új kölcsönható partnerét azonosítottuk, melyeket a Flfl Smk-1 doménjén keresztül köt meg. Ez azt jelentheti, hogy az EVH1 domén mellett az Smk-1-nek is fontos szerepe van a szubsztrátum-felismerésben és kötésben. Felmerült bennünk a kérdés, hogy amennyiben ez így van, úgy az Smk-1-en keresztüli szubsztrátum kötés független-e az EVH1 doméntől, vagyis ezen interakciós partnerek kizárólag az Smk-1 doménnel lépnek kölcsönhatásba, vagy az Smk-1 esetleg az EVH1-nek segít a szubsztrátum kötés stabilizálásában. Ennek vizsgálatára elvégeztük az Smk-1 interakciós partnerek in vitro EVH1 kötési tesztjeit is. Az eredmények alapján az EVH1 domén egyik Smk-1-gyel kölcsönhatásba lépő fehérjét sem képes megkötni (15. ábra), ami arra utal, hogy az Smk-1 szubsztrátum kötése az EVH1-től független módon történik. 

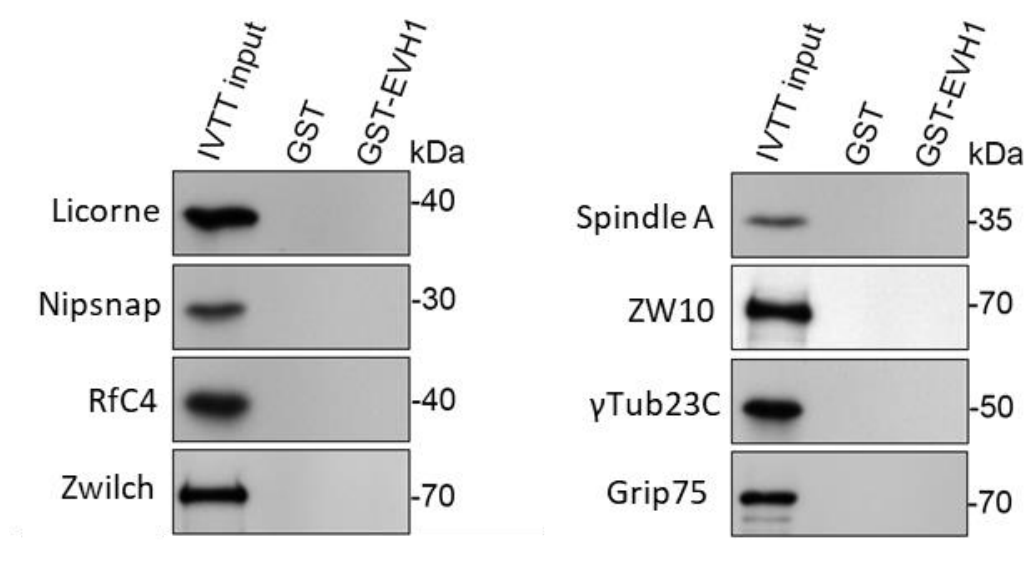

15. ábra. Az Smk-1 interakciós partnerek EVH1 kötési tesztje. Annak vizsgálatára, hogy az Smk-1-el specifikus interakciót mutató fehérjék képesek-e az EVH1-el is kölcsönhatásba lépni, elvégeztük ezen fehérjék in vitro EVH1 kötési tesztjét is. Mivel az EVH1-el egyik sem mutat interakciót, az Smk-1 doménnel való kölcsönhatásuk feltehetően nagy specificitású, az EVH1 doméntől független.

Mivel tudjuk, hogy az EVH1 domén a konzervált FxxP és MxPP motívumokat ismeri fel, megvizsgáltuk, hogy az Smk-1 doménnel kölcsönhatásba lépő fehérjékben találunk-e ilyen motívumokat. Az Smk-1 interakciós partnerek közül csupán egyetlen fehérje, a ZW10 tartalmaz két FxxP motívumot (238-241 és 438-441 aminosavak). Ha az Smk-1-en keresztüli szubsztrátum kötés valóban független az EVH1-től, akkor ezen motívumok módosítása nem járhat az Smk-1 és a ZW10 közötti interakció megszünésével. Ennek vizsgálatára létrehoztuk a ZW10 fehérje két pontmutánsát, melyekben egyenként módosítottuk a 238-241, illetve a 438-441 aminosav szakaszokon található FxxP motívumokat úgy, hogy az első és negyedik pozícióban lévő $\mathrm{F}$, illetve $\mathrm{P}$ aminosavakat A-ra cseréltük. In vivo co-IP kísérleteink alapján ezen motívumok mutációja nincs hatással az Smk-1 és ZW10 közötti interakcióra (16. ábra), ami arra utal, hogy az Smk-1-en keresztüli szubsztrátum kötés valóban egy új, az EVH1 szubsztrátum felismerésétől független módon történik, azonban ennek a pontos mechanizmusának feltárása még további kísérleteket igényel. 


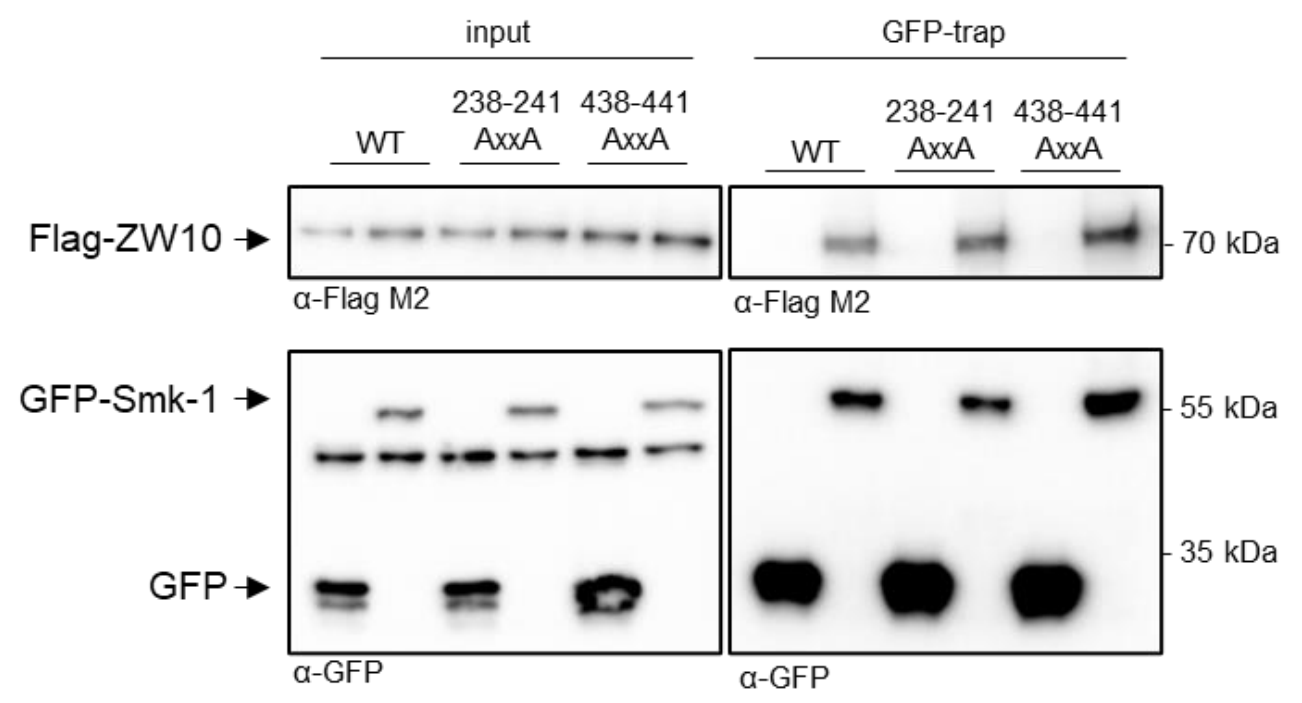

16. ábra. Vad típusú és mutáns ZW10 fehérjék in vivo interakciós vizsgálata. A ZW10 fehérjében található két FxxP motívumot (238-241 és 438-441 aminosavak) külön-külön módosítottuk a teljes hosszúságú fehérje alanin szubsztitúciós mutánsainak létrehozásával. In vivo ko-immunprecipitációs kísérlettel vizsgáltuk, hogy a mutáció milyen hatással van az Smk-1-el való interakcióra. A két felső panelen az $\alpha$-Flag M2 ellenanyaggal hibridizált Flag-ZW10 input (bal) és GFP-trap (jobb) mintái láthatóak. A két alsó panelen a negatív kontrollként használt GFP és a GFP jelölt Smk-1 input (bal) és GFP-trap (jobb) minták láthatóak. A GFP-Smk-1 a vad típusú ZW10 mellett a két mutánst is ugyanolyan erősséggel kötötte meg. A negatív GFP kontrollal egyik esetben sem látható interakció.

\subsection{A PP4/Flfl és CENP-C szabályozó szerepe a Barrier-to-autointegration factor (BAF) foszforegulációjában}

Csoportunk részt vett egy nemzetközi együttmüködésben, melynek célja a BAF fehérje PP4 foszforegulációján keresztüli mitotikus szabályozásban betöltött szerepének vizsgálata volt. Habár a BAF fehérje VRK1 kináz és PP2A foszfatáz általi szabályozása jól ismert, az a BAF heterokromatikus funkciójához köthető. Kiderült, hogy a BAF-nak egy kis része mitózisban a centromérákhoz kötődik, mégpedig a kulcsfontosságú CENP-C centromérikus fehérjén keresztül, amely a PP4 foszfatáznak is platformot képez [48]. Megvizsgáltuk, hogy a centromérikus BAF defoszforilációjában részt vesz-e a PP4. A kísérletes munka nagy része Barcelonában, Ferran Azorín csoportjában zajlott (IRB, Barcelona, Spanyolország), csoportunk a munkához DNS konstrukciókat és stabilan transzfektált D.Mel-2 sejtvonalakat állított elö. Létrehoztunk olyan sejtvonalakat, melyek RNS-interferencia-rezisztens GFP-CENP-C-t termelnek, melyek vagy vad típusúak $\left(\right.$ GFP-CENP-C $\left.{ }^{\mathrm{R}}\right)$, vagy olyan mutánsok $\left(\right.$ GFP-CENP-C $\triangle$ FIM $^{\mathrm{R}}-$ Falafel interakciós 
motívum deficiens, amely nem képes megkötni a PP4 foszfatázt), amik nem kepések dokkolni a PP4-et a centromérán (17. ábra). Továbbá létrehoztunk a BAF GFP-kötő doménnel (GBP) fúzionált változatát a fenti GFP-CENP-C konstrukciókkal együtt termelő stabil sejtvonalakat (endogén CENP-C deficiens háttéren (dsRNA $\left.{ }^{\text {CENP-C }}\right)$ ), ezáltal a BAF-ot mesterségesen, PP4-független módon tudtuk kötni a transzgenikus CENP-Ckhez.

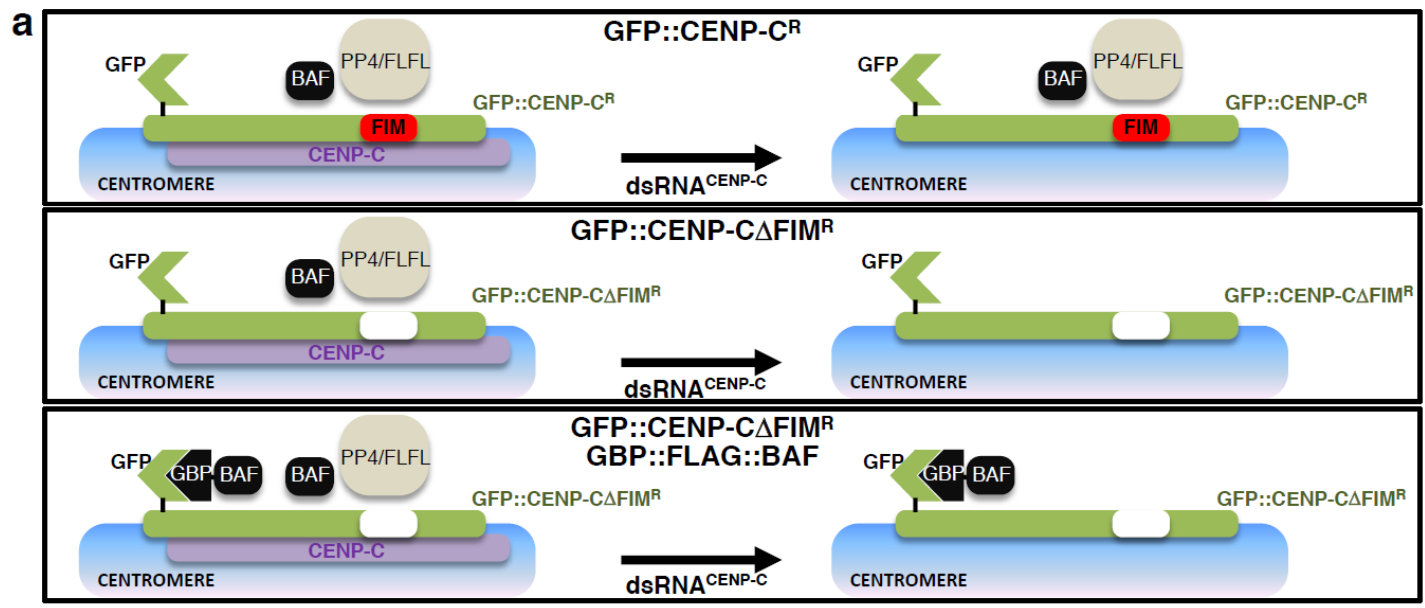

17. ábra. A CENP-C, BAF és PP4/FIfl egymástól függő lokalizációja. Normál körülmények között a CENP-C FIM motívumához kötődve a PP4/Flfl a centromérához viszi a BAF-ot (felső panel). Amennyiben a CENP-C FIM motívumát eltávolítjuk, mind a PP4/Flfl, mind a BAF elveszíti centromérikus lokalizációját (középső panel). Egy GBP fúziós fehérjével ellátva lehetséges a BAF-ot mesterségesen a GFP jelölt, FIM deléciós CENP-C-hez kötni, ezáltal a PP4-től függetlenül vizsgálni (alsó panel). (átvéve: Torras-Llort és munkatársai [77])

A fenti sejtvonalakat használva együttmüködő partnereink kimutatták, hogy a mitózis alatt a BAF nemcsak szabad foszforilált (pBAF) formában van jelen (amely a VRK1 kináz hatása), hanem egy kis populációja defoszforilált marad és a kromoszómák centromérikus régiójához kötődik a CENP-C révén. Ez az úgynevezett centromérikus $\mathrm{BAF}$ (cenBAF) populáció bár jelentéktelennek tünik a totális $\mathrm{BAF}$ mennyiségéhez képest, azonban mégis esszenciális a mitózis folyamatának normális levezényléséhez (17. ábra). A cenBAF kialakulásához szükséges a CENP-C jelenléte, valamint a CENPC által dokkolt PP4 foszfatáz aktivitása is. Ha megakadályozzuk a PP4 kötődését a centromérához (17. ábra középső panel) a BAF is eltünik és komoly mitotikus abberációk figyelhetők meg [77]. Ha kizárjuk a PP4-et a centroméráról de a BAF-ot mesterségesen a CENP-C-hez kötjük, akkor visszaáll a normális cenBAF mennyiség és megfelelően lezajlik a mitózis (17. ábra). 
A CENP-C egy esszenciális fehérje, amely összeköti a centromérát a hatalmas kinetokór komplexummal [165]. Már korábban is feltételeztük, hogy a PP4 nemcsak a CENP-C foszforegulációjáért felelős a centromérán, hanem a CENP-C egyfajta platformot is képez a PP4 számára (is), amely így számos más centromérikus és kinetokór fehérjét is defoszforilálhat [48], többek között a BAF-ot. Ez azt feltételezi, hogy nem minden esetben igaz az az állítás, miszerint a PP4 (vagy más foszfatázok) egy jól definiált SLiM motívumon keresztül kötődik a szubsztrátumához, hanem bizonyos esetekben ezt egy közvetítő fehérjén keresztül valósíthatja meg, indirekt kölcsönhatással. Ezért megvizsgáltuk, hogy a BAF képes-e fizikai kölcsönhatásba lépni a Flfl EVH1 vagy Smk-1 doménjével és kimutattuk, hogy nem (18. ábra). Ez a megfigyelés egy érdekes kérdést vet fel, miszerint az eredeti AP-MS kísérletben azonosított 40, az egyes Falafel doménekkel együtt tisztuló fehérje közül lehetnek olyanok, melyek ugyan nem lépnek fizikai kölcsönhatásba a Falafel-lel, de szubsztrátumai a PP4 foszfatáznak. Ez alatt azt értjük, hogy például egy több alegységes fehérjekomplex esetén nem feltétlen szükséges, hogy a Falafel azt a fehérjét kösse meg, melyet a katalitikus alegység defoszforilál. Ennek vizsgálata egy izgalmas jövőbeli kihívást jelent.
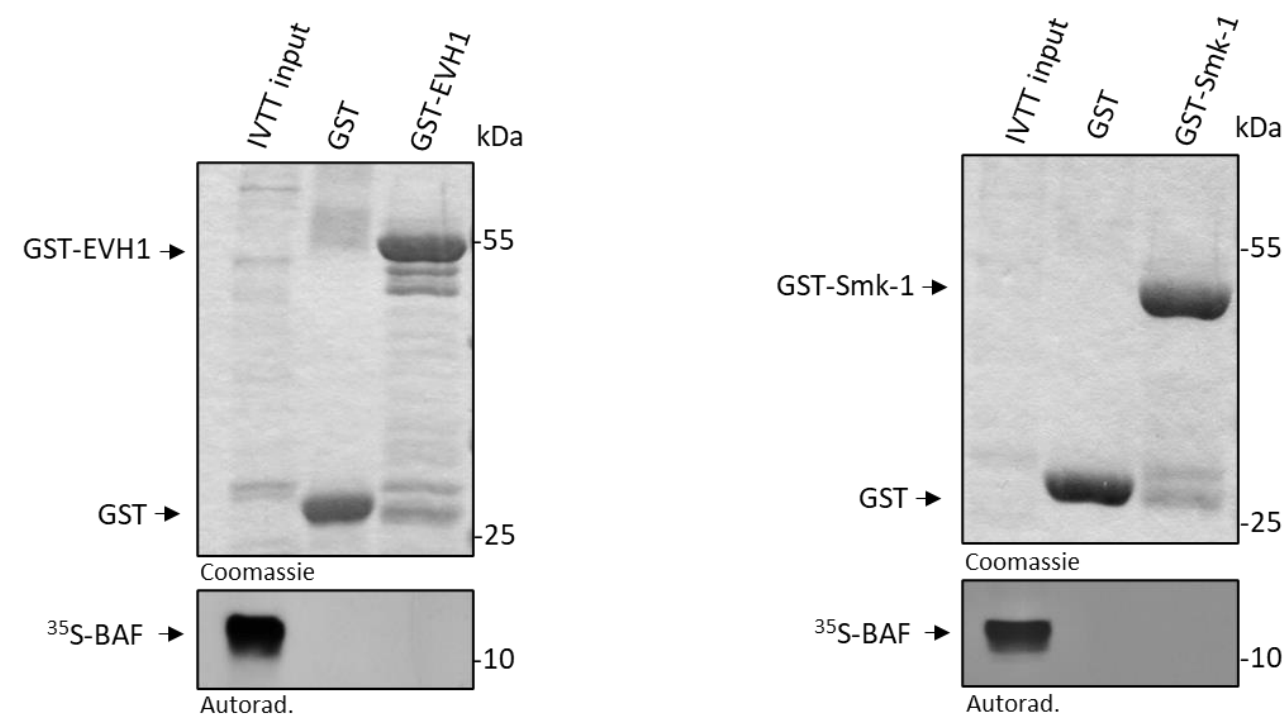

18. ábra. A BAF nem kötődik a Flfl konzervált doménjeihez. In vitro kötési kísérletek alapján a BAF nem lép fizikai kölcsönhatásban sem az EVH1, sem az Smk-1 doménnel. A kísérletekhez negatív kontrollként GST-t használtunk. 


\section{DISZKUSSZIÓ}

A sejthomeosztázis szempontjából a fehérje kinázok és az aktivitásukat ellensúlyozó fehérje foszfatázok térben és időben összehangolt müködése elengedhetetlen. A PP2A-típusú Ser/Thr foszfatázok családjába tartozó PP4 számos fiziológiás folyamat szabályozásában vesz részt, hiánya és túlmüködése egyaránt komoly problémák kialakulásához vezethet. A PP4 katalitikus alegysége a katalitikus aktivitás eléréséhez különböző, evolúciósan erősen konzervált regulátor alegységekkel heterodimer és heterotrimer holoenzim komplexeket alkot. Az R1 és R2 alegységek mellett kiemeltem fontos szerepe van az R3 (Drosophilában Flfl) alegységnek. Bár több olyan fehérjét ismerünk élesztőtől emberig, melyeket egy R3 alegységet is tartalmazó PP4 holoenzim defoszforilál, csupán kevés fehérje esetében bizonyított kísérletesen is, hogy a szubsztrátum megkötését valóban az R3 alegység végzi. Drosophilában mindössze két ilyen fehérjéröl tudunk (CENP-C és Miranda). Tanulmányunk elsődleges célja az volt, hogy feltérképezzük a Drosophila Flfl kölcsönható partnereit, annak érdekében, hogy jobban megismerjük ezen esszenciális foszfatáz szerepét az élő szervezetben, és meghatározzuk a PP4 szubsztrátum-felismerésért felelős motívumát. Egy ilyen motívum azonosításának két előnye is lenne. Egyrészt nagyban megkönnyítené a PP4 foszfatáz új szubsztrátumainak azonosítását és a különböző szubsztrátum-fehérjék szabályozásában betöltött pontos szerepének vizsgálatát. Másrész kiindulási pontként szolgálhatna egy specifikus PP4 gátlószer tervezéséhez, melynek az alapkutatás mellett számos terápiás felhasználási lehetősége is lehetne.

A PP4 foszfatáz interakciós partnereinek azonosítása érdekében vad típusú Drosophila törzsből gyüjtött korai szincíciális embriókból származó lizátumot a kitisztított és gyöngyökön immobilizált GST-EVH1 és GST-Smk-1 fehérjékkel inkubáltuk együtt, majd tömegspektrometriai analízissel meghatároztuk a GST-EVH1 és

a GST-Smk-1 által az embrió-lizátumokból kihalászott fehérjéket. Ezzel a megközelítéssel azonosítottunk 40 fehérjét, mint lehetséges Flfl interakciós partnert (2. táblázat). Az, hogy az EVH1 domén több fehérjét is specifikusan kikötött nem meglepő, ugyanis ezen domén szerepe ismert a Flfl szubsztrátum felismerésében és kötésében. Az EVH1 mellett azonban az Smk-1 domén is számos fehérjét specifikusan megkötött (2. táblázat), ami azért érdekes, hiszen ezen domén funkciója annak ellenére, hogy az EVH1-el azonos fokú konzerváltságot mutat, a mai napig nem tisztázott. 
Az általunk AP-MS módszerrel azonosított, potenciális Flfl-lel kölcsönható partnerek közül (2. táblázat) természetesen nem mind lép valós fizikai kölcsönhatásba a Flfl-lel, ezért in vitro kötési kísérletek segítségével (6. ábra) meghatároztuk az EVH1 és Smk-1 doménekkel tényleges fizikai kölcsönhatást kialakító fehérjéket. Az in vitro kötési kísérletek segítségével az EVH1 domén hét (3. táblázat és 7. ábra), míg az Smk-1 domén nyolc (3. táblázat és 7.ábra) új interakciós partnerét azonosítottuk. Ezen fehérjék különböző intracelluláris képlethez (pl. mitotikus orsó, centroszóma, centroméra) és folyamathoz köthetőek (3. táblázat), ami arra utal, hogy a PP4 a sejten belül több esemény fontos szabályozója.

A konzervált szubsztrátum-felismerési motívum meghatározásához behatároltuk az interakciós felületeket az EVH1 domén és az újonnan azonosított kölcsönható partnerei között. Ehhez az egyes fehérjékből több, egymással átfedő darabot generáltunk, majd in vitro kötési kísérletekkel vizsgáltuk, hogy melyek azok a legrövidebb szakaszok, amelyek az egyes fehérjék esetében szükségesek és elégségesek a kölcsönhatás kialakulásához (6. táblázat).

Lipinszki és munkatársai korábban kimutatták, hogy a Flfl EVH1 doménje és a CENP-C fehérje közötti interakcióhoz mi az a minimális CENP-C régió, ami feltétlen szükséges. Ez a 19 aminosavas szakasz az úgynevezett FIM (Falafel interacting motif), egész pontosan ezen régió közepén elhelyezkedő FKKP aminosavak, ahol is az első és a negyedik pozícióban lévő $\mathrm{F}$ és $\mathrm{P}$ aminosavak esszenciálisak a kölcsönhatás kialakulásához [48]. Mivel a szakirodalomból ismert másik, kísérletesen igazolt EVH1 interakciós fehérje, a Miranda is tartalmaz két, ezen motívumhoz nagyon hasonló régiót (FAIP 77-80 aminosavak és FRTP 92-95 aminosavak) [44], ezért megvizsgáltuk, hogy az általunk igazolt interakciós partnerek is tartalmaznak-e ezekhez hasonló, FxxP motívumokat. A CG8478 kivételével minden fehérje tartalmaz több ilyen motívumot is. Az előzetes, interakciós felület behatárolására vonatkozó eredményeinket felhasználva kiválasztottunk több lehetséges FxxP motívumot, melyekben egyesével, a teljes hosszúságú fehérjékben helyspecifikus mutagenezissel az első és a negyedik pozícióban lévő fenilalanin és prolin aminosavakat alaninra cseréltük, majd megvizsgáltuk, hogy ez milyen hatással van az EVH1-el kialakított kölcsönhatásra. Kísérleteinkkel párhuzamosan, 2019 végén Ueki és munkatársai közzétettek egy tanulmányt, melyben leírták a humán PP4R3 EVH1 konzervált szubsztrátum felismerési motívumát [155], ami megerősítette a Drosophila modellben kapott eredményeinket. Ueki és munkatársai kimutatták, hogy az FxxP motívum mellett a PP4 egy MxPP motívumot is képes 
felismerni és megkötni az EVH1 doménen keresztül [155]. Ezt az információt felhasználva kiterjesztettük vizsgálatainkat ezen motívumokra is, illetve lehetöségünk nyílt a CG8478 további vizsgálatára, ami bár nem tartalmaz egyetlen FxxP motívumot sem, ellenben található rajta egy MxPP motívum.

Érdekes kitérnünk arra, hogy nem csak a használt modellorganizmus, hanem a kísérletes megközelítés is eltérő volt a fentebb említett Ueki és munkatársai, illetve a mi csoportunk munkája között. Ök kiindulási pontként egy olyan fág-könyvtárat használtak, amely a humán proteóm rendezetlen részeit reprezentálja 16 aminosavas peptidek formájában. A PP4 által felismert szekvenciát úgy dúsították, hogy a PP4 regulátor alegységeit (R2, R3A és R3B), illetve az R3 alegység EVH1 doménjét használták, majd újgenerációs szekvenálással azonosították a gyakori motívumokat. Mind az R3A és R3B alegységek, mind az EVH1 domén esetében is az FxxP motívum nagy mértékü dúsulását tapasztalták, illetve néhány peptid esetében az MxPP motívumét, melyet az FxxP egy változataként jellemeztek. Ez után a két motívumot hozzánk hasonlóan mutagenezis segítségével azonosították, majd modell fehérjék segítségével meghatározták a kötési affinitásokat is. A PP4 foszfatáz nagyfokú evolúciós konzerváltságára remek példa, hogy a két, alapvetően eltérő kísérletes módszertan és vizsgált organizmus is ugyanazokhoz a megállapításokhoz vezette a két, egymástól független kutatócsoportot. Ez a kölcsönhatás azonban nagy valószínüséggel nem csak a PP4, hanem az EVH1 interakciós partnereinek részéről is erős funkcionális konzerváltságot mutat. A Prp16 és Centrobin fehérjéket minkét csoport azonosította, mint EVH-1 kölcsönható partner. A Prp16 esetén a két ortológ nagyfokú szekvencia homológiát mutat, a motívumok nagyban megegyeznek (Hs_Prp16: FKAP, 36-39 aminosav; Dm_Prp16: FKKP, 98-101 aminosav, 13. ábra), és mindkét organizmusban a fehérje N-terminálisán található a PP4 felismerési motívum. A Centrobin esetében azonban a két ortológ csak funkcionális konzerváltságot mutat, ugyanis az aminosav szekvenciák nagyban eltérnek. E mellett nem csak a motívumok eltérőek (Hs_Centrobin: FRVP, 741-744 aminosav; Dm_Centrobin: MPPP, 36-39 aminosav, 13. ábra), de ráadásul míg emberben a fehérje C-terminálisán, addig ecetmuslicában a fehérje N-terminálisán található a felismerési szekvencia. Ez arra utal, hogy bár a PP4 kölcsönható partnerei evolúciósan konzerváltak, a foszfatáz egy adott interakciós partnerét eltérő motívumok alapján ismerheti fel különböző fajokban. Ezt tovább erősíti az a tény is, hogy az általunk vizsgált Drosophila fehérjéket a humán EVH1 domén is képes volt megkötni. 
Megállapítottuk, hogy annak ellenére, hogy akár több FxxP és/vagy MxPP motívumot is tartalmazhat egy EVH1-hez kötődő fehérje, ezen motívumok közül van egy kiemelt, aminek a mutációja az interakció nagymértékü gyengüléséhez vagy akár teljes megszünéséhez vezet (12. és13. ábra). In silico módszerek segítségével (IUPred [166]) prediktáltuk az új PP4 interakciós fehérjék szerkezeti rendezettségét, melyből azt láttuk, hogy az általunk kötődés szempontjából kritikusnak azonosított motívumok a fehérjék rendezetlen szakaszain helyezkednek el. Azonban ebből végleges következtetés még nem vonható le, ugyanis az esetek nagy részében más, az interakció szempontjából nem kritikus motívumok is rendezetlen régióban helyezkednek el. Arra, hogy a PP4 R3 alegysége hogyan tesz különbséget az egyes motívumok között és választja ki a megfelelőt, mindenképp a szerkezet szintjén keresendő a válasz, azonban erre a szerkezeti rendezettség/rendezetlenség mellett hatással lehet az egyes motívumok közvetlen aminosav környezete, illetve a motívumok 3D-s szerkezetben elfoglalt helyzete, továbbá a fehérje foszforiláltsági állapota és a foszforilált aminosav helye is.

Az EVH1 és interakciós partnerei közötti kapcsolatot érdemes megvizsgálni nemcsak a kölcsönható fehérjék, de az EVH1 oldaláról is. Lipinszki és munkatársai korábbi röntgenkrisztallográfiás eredményei alapján tudjuk, hogy az EVH1/CENP-C interakcióban kiemelten fontos az EVH1 70. pozíciójában található leucin [48]. Míg a kanonikus EVH1 domének esetében, melyek prolin gazdag régiókat kötnek meg, ebben a pozícióban egy fenilalanin található, addig a PP4R3 ortológok esetében ez az aminosav egy konzervált leucin. Létrehoztuk az EVH1 domén egy mutánsát, ahol ezt a konzervált leucint alaninra cseréltük (Dm-EVH1 $\left.{ }^{\mathrm{L} 70 \mathrm{~A}}\right)$. A korábban azonosított EVH1 interakciós fehérjék segítségével megvizsgáltuk, hogy milyen hatással van ez az aminosav csere az interakcióra. Azt találtuk, hogy a leucin alaninra cserélése az interakció teljes eltünéséhez vezet (14. ábra B). Mivel a Drosophila Flfl és a humán SMEK1 alegységek nagyfokú homológiát mutatnak (14. ábra A), a konzervált leucin utóbbi esetén a 69. aminosav, ezért a SMEK1 EVH1-nek is létrehoztuk egy mutánsát (Hs-EVH1 $\left.{ }^{\mathrm{L} 69 \mathrm{~A}}\right)$, majd megvizsgáltuk a mutáció interakciókra gyakorolt hatását (14. ábra B). Az eredmények alapján két fontos megállapítást tettünk. Egyrészt a Drosophila és ember esetén is konzervált leucin valóban nélkülözhetetlen a szubsztrátumok megkötése szempontjából. Másrészt a PP4 EVH1 doménen keresztüli szubsztrátum kötési mechanizmusa erősen konzervált Drosophila és ember között, ugyanis az emberi SMEK1 EVH1 doménje képes volt megkötni a vizsgált Drosophila fehérjéket, a konzervált leucin mutációja pedig ugyancsak az interakció teljes megszünését okozta (14. ábra B). 
A Flfl Smk-1 doménje bár az EVH1-el megegyező fokú konzerváltságot mutat, azonban funkciója még tisztázatlan. Megvizsgáltuk, hogy az általunk azonosított fehérjék esetében, melyek a Flfl Smk-1 doménjével lépnek specifikus kölcsönhatásba, hogy ez az interakció valóban az Smk-1-re specifikus-e. Ennek eldöntésére elvégeztük ezen fehérjék EVH1 kötési tesztjét is. A kölcsönhatások valóban minden esetben kizárólag az Smk-1 doménhez köthetőek, ugyanis az EVH1-hez egyik fehérje sem kötődött (15. ábra). Az EVH1 domén kölcsönható partnereihez hasonlóan az Smk-1-gyel kölcsönhatásba lépő fehérjék esetén szintén meghatároztuk a minimális interakciós felületeket (6. táblázat). Az FxxP és MxPP motívum ismeretében megvizsgáltuk, hogy bármely Smk-1 kölcsönható partner rendelkezik-e ezen motívumokkal. A fehérjék közül csupán a ZW10 tartalmaz két FxxP (238-241 és 438-441 aminosavak) motívumot, azonban ezek helyspecifikus mutagenezise a teljes hosszúságú fehérjében nincs hatással az Smk-1-al kialakított kölcsönhatásra (16. ábra). Ezek alapján arra következtethetünk, hogy a Flfl ismeretlen funkciójú Smk-1 doménje nagy valószínűséggel szintén fontos szerepet játszhat a PP4 szubsztrátum kötésében. Kísérleti eredményeink alapján azt feltételezzük, hogy az Smk-1 doménen keresztüli fehérje kötés az EVH1 doméntől független és eltérő módon történik, azonban pontos mechanizmusának meghatározásához még további vizsgálatok elvégzése szükséges.

Azok alapján, hogy a PP4 regulátor alegységének doménjei képesek megkötni bizonyos fehérjéket, még nem következik az, hogy az adott fehérjék egyben a PP4 szubsztrátumai is. Annak megállapítására, hogy a kölcsönható fehérjék a PP4 szubsztrátjai-e, már végeztünk méréseket (M3. ábra). Kísérleteinkben D.Mel-2 sejteket kezeltünk okadainsavval, ami a PP2A típusú foszfatázok szelektív gátlószere. Az általunk azonosított interakciós fehérjék foszforilációs állapotát vizsgáltuk mind kezeletlen, mind okadainsavval kezelt sejtekben ún. gél-retardációs teszttel. Ennek alapja, hogy a foszforilált fehérjék klasszikus vagy foszforilációt detektáló denaturáló poliakrilamid gélben lassabban vándorolnak, mint a foszforilálatlan formák a gélelektroforézis során, amit pl. Western-blot technikával ki lehet mutatni. Számos fehérje esetében (M3. ábra) sikerült igazolni, hogy az valamilyen PP2A-típusú foszfatáz szabályozása alatt áll. Ugyanakkor, megismételve a kísérletet olyan sejtekben, amikben RNS-interferencia segítségével (ami nagyon hatékony muslica sejtekben) csendesítettük a PP4-et, nem tudtunk kimutatni eltérést a kontroll és kezelt sejtekben kifejezett PP4-kölcsönható fehérjék méretében. Annak megválaszolására, hogy az általunk azonosított fehérjék a PP4 
szubsztrátumai-e, egy lehetséges megoldást jelenthet a foszforilált kölcsönható partnerek tisztítása és foszfoproteomikai analízise, de ez még számos további kísérletet igényel.

A Barrier-to-autointegration factor (BAF) egy evolúciósan konzervált sejtmagmembrán komponens, melynek kiemelten fontos szerepe van a kromatin sejtmagmembránhoz való kötődésében. A mitózis alatt ez a fehérje nagyrészt szabad, foszforilált formában van jelen, azonban egy kis, defoszforilált populációja a centromérákhoz kötődik, ahol fontos szabályozó szerepet tölt be [77]. A cenBAF defoszforilált állapotának és ezáltal centromérikus lokalizációjának fenntartásáért a PP4/Flfl felelős. A BAF azonban nem alakít ki fizikai kölcsönhatást sem a Flfl EVH1, sem az Smk-1 doménjével (18. ábra), ami felveti a PP4 szubsztrátum felismerésének egy lehetséges harmadik, az EVH1 és az Smk-1 doménektől független módját. Ebben az esetben a fehérje szubsztrátumot nem az EVH1 vagy Smk-1 domének kötik meg, hanem a Flfl a PP4-et egy közvetítő fehérjéhez köti (pl. CENP-C), melynek révén a PP4 a centromérán jelen lévő különböző fehérjéket defoszforilálhat. Ezt a közvetett módot is beleszámítva a PP4 foszfatáz a Flfl alegységen keresztül három különböző módon is képes szubsztrátumait elérni.

A PP4 foszfatáz szubsztrátum felismerésének még alaposabb megértéséhez a jövőben két fö irányban érdemes folytatni vizsgálatainkat. Az Smk-1 domén PP4 interakciós partnerek kötésében betöltött szerepének megértéséhez szükséges meghatározni az Smk-1 és egy vagy több kölcsönható partnerének 3D-s kristályszerkezetét. Ez egyrészt választ adna arra, hogy az Smk1-nek pontosan mely aminosavai vesznek részt a kölcsönható fehérjék megkötésében, másrészt nagyban elősegítené az Smk-1 felismerési szekvencia azonosítását. Ezen információk birtokában tisztázhatnánk egy, a szakirodalomban már régóta leírt, de mégis ismeretlen funkciójú domén szerepét. A másik fontos feladat annak meghatározása, hogy az általunk azonosított EVH1 és Smk-1 kölcsönható partnerek közül melyek a PP4 szubsztrátumai és a foszfatáz mely aminosavaikat képes defoszforilálni, azonban ezek megállapítása még további komplex in vivo és in vitro kísérleteket igényel. Ezek elvégzése révén még jobban megismerhetjük és megérthetjük a PP4 által szabályozott folyamatok molekuláris hátterét. 


\section{KÖSZÖNETNYILVÁNÍTÁS}

Szeretném megköszönni témavezetőmnek, Dr. Lipinszki Zoltánnak a lehetőséget, hogy kutatócsoportjában elsajátíthattam a genetikai, biokémiai és molekuláris biológiai technikákat és ismereteket! Hálás vagyok az irántam tanúsított bizalmáért és tanácsaiért, melyekkel önálló kutatómunkára és folyamatos fejlődésre ösztönzött! Köszönöm a mindenre kiterjedő nélkülözhetetlen segítségét és türelmét!

Hálával tartozom Dr. Udvardy Andornak, hogy szakmai kérdéseimmel mindig bizalommal fordulhattam hozzá!

Hálásan köszönöm Dr. Ábrahám Editnek a megszámlálhatatlan szakmai tanácsot és a folyamatos biztatást, amivel támogatta munkámat!

Köszönöm Dr. Fábri-Ördögh Lillának és Réthi-Nagy Zsuzsánnának a kísérletek kivitelezésében nyújtott segítséget!

Köszönöm Dr. Sinka Ritának és Dr. Kiss Antalnak a doktori értekezésem formai és tartalmi részére vonatkozó javaslatait!

Köszönöm a munkatársaimnak, hogy mindig barátsággal fordultak hozzám!

Köszönöm a szakmai tanácsokat és segítséget az SZBK Biokémiai Intézet valamennyi munkatársának!

Végtelen hálával tartozom családomnak, páromnak és barátaimnak az odaadó támogatásukért és türelmükért, amely nélkül a dolgozatom nem készülhetett volna el!

Kutatómunkánkat az SZTE Biológia Doktori Iskola (PhD Ösztöndíj), két GINOP támogatás (GINOP-2.3.2-15-2016-00001 és GINOP-2.3.2-15-2016-00032), egy OTKA program (OTKA-PD115404), valamint a Magyar Tudományos Akadémia Lendület programja (LP2017- 7/2017) támogatta. 


\section{IRODALOMJEGYZÉK}

1. Khoury, G.A., R.C. Baliban, and C.A. Floudas, Proteome-wide post-translational modification statistics: frequency analysis and curation of the swiss-prot database. Sci Rep, 2011. 1.

2. Fontanillo, M. and M. Kohn, Phosphatases: Their Roles in Cancer and Their Chemical Modulators. Adv Exp Med Biol, 2016. 917: p. 209-40.

3. Fahs, S., P. Lujan, and M. Kohn, Approaches to Study Phosphatases. ACS Chem Biol, 2016. 11(11): p. 2944-2961.

4. Salazar, C. and T. Hofer, Multisite protein phosphorylation--from molecular mechanisms to kinetic models. FEBS J, 2009. 276(12): p. 3177-98.

5. Hanks, S.K. and T. Hunter, Protein kinases 6. The eukaryotic protein kinase superfamily: kinase (catalytic) domain structure and classification. FASEB J, 1995. 9(8): p. 576-96.

6. Sebastian, B., A. Kakizuka, and T. Hunter, Cdc25M2 activation of cyclin-dependent kinases by dephosphorylation of threonine-14 and tyrosine-15. Proc Natl Acad Sci U S A, 1993. 90(8): p. 3521-4.

7. Yaffe, M.B. and S.J. Smerdon, PhosphoSerine/threonine binding domains: you can't pSERious? Structure, 2001. 9(3): p. R33-8.

8. Reinhardt, H.C. and M.B. Yaffe, Phospho-Ser/Thr-binding domains: navigating the cell cycle and DNA damage response. Nat Rev Mol Cell Biol, 2013. 14(9): p. 563-80.

9. Nishi, H., K. Hashimoto, and A.R. Panchenko, Phosphorylation in protein-protein binding: effect on stability and function. Structure, 2011. 19(12): p. 1807-15.

10. Kleiman, L.B., et al., Rapid phospho-turnover by receptor tyrosine kinases impacts downstream signaling and drug binding. Mol Cell, 2011. 43(5): p. 723-37.

11. Cohen, P.T., Protein phosphatase 1--targeted in many directions. J Cell Sci, 2002. 115(Pt 2): p. 241-56.

12. Virshup, D.M. and S. Shenolikar, From promiscuity to precision: protein phosphatases get a makeover. Mol Cell, 2009. 33(5): p. 537-45.

13. Wlodarchak, N. and Y. Xing, PP2A as a master regulator of the cell cycle. Crit Rev Biochem Mol Biol, 2016. 51(3): p. 162-84.

14. Sharma, K., et al., Ultradeep human phosphoproteome reveals a distinct regulatory nature of Tyr and Ser/Thr-based signaling. Cell Rep, 2014. 8(5): p. 1583-94.

15. Lemmon, M.A., et al., The Dark Side of Cell Signaling: Positive Roles for Negative Regulators. Cell, 2016. 164(6): p. 1172-1184.

16. Heinrich, R., B.G. Neel, and T.A. Rapoport, Mathematical models of protein kinase signal transduction. Mol Cell, 2002. 9(5): p. 957-70.

17. Gelens, L., et al., The Importance of Kinase-Phosphatase Integration: Lessons from Mitosis. Trends Cell Biol, 2018. 28(1): p. 6-21.

18. Shi, Y., Serine/threonine phosphatases: mechanism through structure. Cell, 2009. 139(3): p. 468-84.

19. Kelker, M.S., R. Page, and W. Peti, Crystal structures of protein phosphatase-1 bound to nodularin-R and tautomycin: a novel scaffold for structure-based drug design of serine/threonine phosphatase inhibitors. J Mol Biol, 2009. 385(1): p. 11-21.

20. Singh, A., et al., Plant protein phosphatases $2 C$ : from genomic diversity to functional multiplicity and importance in stress management. Crit Rev Biotechnol, 2016. 36(6): p. 1023-1035.

21. Lammers, T. and S. Lavi, Role of type $2 C$ protein phosphatases in growth regulation and in cellular stress signaling. Crit Rev Biochem Mol Biol, 2007. 42(6): p. 437-61.

22. Moura, M. and C. Conde, Phosphatases in Mitosis: Roles and Regulation. Biomolecules, 2019. 9(2).

23. Brautigan, D.L. and S. Shenolikar, Protein Serine/Threonine Phosphatases: Keys to Unlocking Regulators and Substrates. Annu Rev Biochem, 2018. 87: p. 921-964. 
24. Bastians, H. and H. Ponstingl, The novel human protein serine/threonine phosphatase 6 is a functional homologue of budding yeast Sit4p and fission yeast ppel, which are involved in cell cycle regulation. J Cell Sci, 1996. 109 ( Pt 12): p. 2865-74.

25. Morales-Johansson, H., et al., Human protein phosphatase PP6 regulatory subunits provide Sit4-dependent and rapamycin-sensitive sap function in Saccharomyces cerevisiae. PLoS One, 2009. 4(7): p. e6331.

26. Seifried, A., J. Schultz, and A. Gohla, Human HAD phosphatases: structure, mechanism, and roles in health and disease. FEBS J, 2013. 280(2): p. 549-71.

27. Mayfield, J.E., N.T. Burkholder, and Y.J. Zhang, Dephosphorylating eukaryotic RNA polymerase II. Biochim Biophys Acta, 2016. 1864(4): p. 372-87.

28. Brewis, N.D., et al., PPX, a novel protein serine/threonine phosphatase localized to centrosomes. EMBO J, 1993. 12(3): p. 987-96.

29. Lee, D.H., et al., A PP4 phosphatase complex dephosphorylates RPA2 to facilitate DNA repair via homologous recombination. Nat Struct Mol Biol, 2010. 17(3): p. 365-72.

30. Lee, D.H., et al., Phosphoproteomic analysis reveals that PP4 dephosphorylates KAP-1 impacting the DNA damage response. EMBO J, 2012. 31(10): p. 2403-15.

31. Lee, J., et al., Dephosphorylation of DBC1 by Protein Phosphatase 4 Is Important for p53-Mediated Cellular Functions. Mol Cells, 2015. 38(8): p. 697-704.

32. Lee, D.H., et al., Dephosphorylation enables the recruitment of 53BP1 to double-strand DNA breaks. Mol Cell, 2014. 54(3): p. 512-25.

33. Chen, G.I., et al., PP4R4/KIAA1622 forms a novel stable cytosolic complex with phosphoprotein phosphatase 4. J Biol Chem, 2008. 283(43): p. 29273-84.

34. Hastie, C.J., et al., A novel $50 \mathrm{kDa}$ protein forms complexes with protein phosphatase 4 and is located at centrosomal microtubule organizing centres. Biochem J, 2000. $347 \mathbf{P t}$ 3: p. 845-55.

35. Kloeker, S. and B.E. Wadzinski, Purification and identification of a novel subunit of protein serine/threonine phosphatase 4. J Biol Chem, 1999. 274(9): p. 5339-47.

36. Huang, X., A. Cheng, and R.E. Honkanen, Genomic organization of the human PP4 gene encoding a serine/threonine protein phosphatase (PP4) suggests a common ancestry with PP2A. Genomics, 1997. 44(3): p. 336-43.

37. Bastians, H., et al., Assignment of the human serine/threonine protein phosphatase 4 gene (PPP4C) to chromosome 16p11-p12 by fluorescence in situ hybridization. Genomics, 1997. 42(1): p. 181-2.

38. Hastie, C.J. and P.T. Cohen, Purification of protein phosphatase 4 catalytic subunit: inhibition by the antitumour drug fostriecin and other tumour suppressors and promoters. FEBS Lett, 1998. 431(3): p. 357-61.

39. Kloeker, S., et al., Carboxymethylation of nuclear protein serine/threonine phosphatase X. Biochem J, 1997. 327 ( Pt 2): p. 481-6.

40. Pereira, S.R., V.M. Vasconcelos, and A. Antunes, Computational study of the covalent bonding of microcystins to cysteine residues--a reaction involved in the inhibition of the PPP family of protein phosphatases. FEBS J, 2013. 280(2): p. 674-80.

41. Gingras, A.C., et al., A novel, evolutionarily conserved protein phosphatase complex involved in cisplatin sensitivity. Mol Cell Proteomics, 2005. 4(11): p. 1725-40.

42. Lyu, J., et al., Protein phosphatase 4 and Smek complex negatively regulate Par3 and promote neuronal differentiation of neural stem/progenitor cells. Cell Rep, 2013. 5(3): p. 593-600.

43. Ma, H., et al., Psy2 targets the PP4 family phosphatase Pph3 to dephosphorylate Mth1 and repress glucose transporter gene expression. Mol Cell Biol, 2014. 34(3): p. 452-63.

44. Sousa-Nunes, R., W. Chia, and W.G. Somers, Protein phosphatase 4 mediates localization of the Miranda complex during Drosophila neuroblast asymmetric divisions. Genes Dev, 2009. 23(3): p. 359-72.

45. Gavin, A.C., et al., Functional organization of the yeast proteome by systematic analysis of protein complexes. Nature, 2002. 415(6868): p. 141-7.

46. Ho, Y., et al., Systematic identification of protein complexes in Saccharomyces cerevisiae by mass spectrometry. Nature, 2002. 415(6868): p. 180-3. 
47. Zarske, M. and E. Hafen, 44th Annual Drosophila Research Conference 5-9. The Genetics Society of America, 2003.

48. Lipinszki, Z., et al., Centromeric binding and activity of Protein Phosphatase 4. Nat Commun, 2015. 6: p. 5894.

49. LeNoue-Newton, M.L., B.E. Wadzinski, and B.W. Spiller, The three Type 2A protein phosphatases, PP2Ac, PP4c and PP6c, are differentially regulated by Alpha4. Biochem Biophys Res Commun, 2016. 475(1): p. 64-9.

50. Ahn, H.K., et al., Functional characterization of chaperonin containing T-complex polypeptide-1 and its conserved and novel substrates in Arabidopsis. J Exp Bot, 2019. 70(10): p. 2741-2757.

51. Nanahoshi, M., et al., Alpha4 protein as a common regulator of type 2A-related serine/threonine protein phosphatases. FEBS Lett, 1999. 446(1): p. 108-12.

52. $\quad$ Chen, J., R.T. Peterson, and S.L. Schreiber, Alpha 4 associates with protein phosphatases 2A, 4, and 6. Biochem Biophys Res Commun, 1998. 247(3): p. 827-32.

53. Lee, J. and D.H. Lee, Leucine methylation of protein phosphatase PP4C at C-terminal is critical for its cellular functions. Biochem Biophys Res Commun, 2014. 452(1): p. 42-7.

54. Hwang, J., J.A. Lee, and D.C. Pallas, Leucine Carboxyl Methyltransferase 1 (LCMT-1) Methylates Protein Phosphatase 4 (PP4) and Protein Phosphatase 6 (PP6) and Differentially Regulates the Stable Formation of Different PP4 Holoenzymes. J Biol Chem, 2016. 291(40): p. 21008-21019.

55. Hu, M.C., et al., Genomic structure of the mouse PP4 gene: a developmentally regulated protein phosphatase. Gene, 2001. 278(1-2): p. 89-99.

56. Voss, M., et al., Protein phosphatase 4 is phosphorylated and inactivated by Cdk in response to spindle toxins and interacts with gamma-tubulin. Cell Cycle, 2013. 12(17): p. 2876-87.

57. Hu, M.C., et al., Protein phosphatase X interacts with c-Rel and stimulates $c$ Rel/nuclear factor kappaB activity. J Biol Chem, 1998. 273(50): p. 33561-5.

58. Brewis, N.D. and P.T. Cohen, Protein phosphatase X has been highly conserved during mammalian evolution. Biochim Biophys Acta, 1992. 1171(2): p. 231-3.

59. Koh, C.G., S.H. Oon, and S. Brenner, Serine/threonine phosphatases of the pufferfish, Fugu rubripes. Gene, 1997. 198(1-2): p. 223-8.

60. Jia, S., et al., Protein phosphatase 4 cooperates with Smads to promote BMP signaling in dorsoventral patterning of zebrafish embryos. Dev Cell, 2012. 22(5): p. 1065-78.

61. Helps, N.R., et al., Protein phosphatase 4 is an essential enzyme required for organisation of microtubules at centrosomes in Drosophila embryos. J Cell Sci, 1998. 111 ( Pt 10): p. 1331-40.

62. Wu, H.I., et al., Genome-wide identification of genes conferring resistance to the anticancer agents cisplatin, oxaliplatin, and mitomycin C. Cancer Res, 2004. 64(11): p. 3940-8.

63. Ronne, H., et al., Protein phosphatase 2A in Saccharomyces cerevisiae: effects on cell growth and bud morphogenesis. Mol Cell Biol, 1991. 11(10): p. 4876-84.

64. Hazbun, T.R., et al., Assigning function to yeast proteins by integration of technologies. Mol Cell, 2003. 12(6): p. 1353-65.

65. Hastie, C.J., et al., The Saccharomyces cerevisiae orthologue of the human protein phosphatase 4 core regulatory subunit $R 2$ confers resistance to the anticancer drug cisplatin. FEBS J, 2006. 273(14): p. 3322-34.

66. Pujol, G., et al., The Arabidopsis thaliana PPX/PP4 phosphatases: molecular cloning and structural organization of the genes and immunolocalization of the proteins to plastids. Plant Mol Biol, 2000. 44(4): p. 499-511.

67. Mendoza, M.C., et al., MEK1 and protein phosphatase 4 coordinate Dictyostelium development and chemotaxis. Mol Cell Biol, 2007. 27(10): p. 3817-27.

68. Hall, E.T., et al., The protein phosphatase 4 complex promotes the Notch pathway and wingless transcription. Biol Open, 2017. 6(8): p. 1165-1173. 
69. Jia, H., et al., PP4 and PP2A regulate Hedgehog signaling by controlling Smo and Ci phosphorylation. Development, 2009. 136(2): p. 307-16.

70. Van Dolah, F.M. and J.S. Ramsdell, Okadaic acid inhibits a protein phosphatase activity involved in formation of the mitotic spindle of GH4 rat pituitary cells. J Cell Physiol, 1992. 152(1): p. 190-8.

71. Martin-Granados, C., et al., Depletion of protein phosphatase 4 in human cells reveals essential roles in centrosome maturation, cell migration and the regulation of Rho GTPases. Int J Biochem Cell Biol, 2008. 40(10): p. 2315-32.

72. Sumiyoshi, E., A. Sugimoto, and M. Yamamoto, Protein phosphatase 4 is required for centrosome maturation in mitosis and sperm meiosis in C. elegans. J Cell Sci, 2002. 115(Pt 7): p. 1403-10.

73. Carnegie, G.K., et al., Protein phosphatase 4 interacts with the Survival of Motor Neurons complex and enhances the temporal localisation of snRNPs. J Cell Sci, 2003. 116(Pt 10): p. 1905-13.

74. Huang, X., et al., Protein phosphatase 4 plays dual roles during cell proliferation. Cell Prolif, 2016. 49(2): p. 219-35.

75. Han, X., et al., The role of protein phosphatase 4 in regulating microtubule severing in the Caenorhabditis elegans embryo. Genetics, 2009. 181(3): p. 933-43.

76. Toyo-oka, K., et al., Protein phosphatase 4 catalytic subunit regulates Cdk1 activity and microtubule organization via NDEL1 dephosphorylation. J Cell Biol, 2008. 180(6): p. $1133-47$.

77. Torras-Llort, M., et al., A fraction of barrier-to-autointegration factor (BAF) associates with centromeres and controls mitosis progression. Commun Biol, 2020. 3(1): p. 454.

78. Falk, J.E., et al., A Mecl-and PP4-dependent checkpoint couples centromere pairing to meiotic recombination. Dev Cell, 2010. 19(4): p. 599-611.

79. Sato-Carlton, A., et al., Protein phosphatase 4 promotes chromosome pairing and synapsis, and contributes to maintaining crossover competence with increasing age. PLoS Genet, 2014. 10(10): p. e1004638.

80. Birot, A., et al., A second Wpll anti-cohesion pathway requires dephosphorylation of fission yeast kleisin Rad21 by PP4. EMBO J, 2017. 36(10): p. 1364-1378.

81. Zhuang, X., et al., Dephosphorylation of barrier-to-autointegration factor by protein phosphatase 4 and its role in cell mitosis. J Biol Chem, 2014. 289(2): p. 1119-27.

82. Furukawa, K., et al., Barrier-to-autointegration factor plays crucial roles in cell cycle progression and nuclear organization in Drosophila. J Cell Sci, 2003. 116(Pt 18): p. 3811-23.

83. Margalit, A., et al., Barrier-to-autointegration factor is required to segregate and enclose chromosomes within the nuclear envelope and assemble the nuclear lamina. Proc Natl Acad Sci U S A, 2005. 102(9): p. 3290-5.

84. Segura-Totten, M., et al., Barrier-to-autointegration factor: major roles in chromatin decondensation and nuclear assembly. J Cell Biol, 2002. 158(3): p. 475-85.

85. Asencio, C., et al., Coordination of kinase and phosphatase activities by Lem4 enables nuclear envelope reassembly during mitosis. Cell, 2012. 150(1): p. 122-35.

86. Theobald, B., et al., Suppression of Ser/Thr phosphatase 4 (PP4C/PPP4C) mimics a novel post-mitotic action of fostriecin, producing mitotic slippage followed by tetraploid cell death. Mol Cancer Res, 2013. 11(8): p. 845-55.

87. Dong, S.M., et al., Tumor suppressor BLU enhances pro-apoptotic activity of sMEKI through physical interaction. Cell Signal, 2012. 24(6): p. 1208-14.

88. Qi, Y., et al., Lentivirus-Mediated Short-Hairpin RNA Targeting Protein Phosphatase 4 Regulatory Subunit 1 Inhibits Growth in Breast Cancer. J Breast Cancer, 2015. 18(3): p. 218-24.

89. Mohammed, H.N., M.R. Pickard, and M. Mourtada-Maarabouni, The protein phosphatase 4 - PEA15 axis regulates the survival of breast cancer cells. Cell Signal, 2016. 28(9): p. 1389-400. 
90. Zhu, Y., et al., Knockdown of protein phosphatase 4 regulatory subunit 1 inhibits growth of lung cancer cells in vitro 2016.pdf. Int J Clin Exp Med, 2016. 9(6): p. 1051310520.

91. Weng, S., et al., Overexpression of protein phosphatase 4 correlates with poor prognosis in patients with stage II pancreatic ductal adenocarcinoma. Cancer Epidemiol Biomarkers Prev, 2012. 21(8): p. 1336-43.

92. Li, X., et al., High expression of protein phosphatase 4 is associated with the aggressive malignant behavior of colorectal carcinoma. Mol Cancer, 2015. 14: p. 95.

93. Inostroza, J., et al., Role of the phosphatase PP4 in the activation of JNK-1 in prostate carcinoma cell lines $P C-3$ and LNCaP resulting in increased AP-1 and EGR-1 activity. Biol Res, 2005. 38(2-3): p. 163-78.

94. Li, M., et al., Protein phosphatase 4 catalytic subunit is overexpressed in glioma and promotes glioma cell proliferation and invasion. Tumour Biol, 2016. 37(9): p. 1189311901.

95. Mourtada-Maarabouni, M. and G.T. Williams, Protein phosphatase 4 regulates apoptosis, proliferation and mutation rate of human cells. Biochim Biophys Acta, 2008. 1783(8): p. 1490-502.

96. Wandzioch, E., et al., PME-1 modulates protein phosphatase $2 A$ activity to promote the malignant phenotype of endometrial cancer cells. Cancer Res, 2014. 74(16): p. 4295305.

97. Zhang, F., et al., Phosphotyrosyl phosphatase activator facilitates localization of Miranda through dephosphorylation in dividing neuroblasts. Development, 2016. 143(1): p. 35-44.

98. Moon, B.S., et al., Smek promotes corticogenesis through regulating Mbd3's stability and Mbd3/NuRD complex recruitment to genes associated with neurogenesis. PLoS Biol, 2017. 15(5): p. e2001220.

99. Bosio, Y., et al., PPP4R2 regulates neuronal cell differentiation and survival, functionally cooperating with SMN. Eur J Cell Biol, 2012. 91(8): p. 662-74.

100. Zhang, X., et al., Histone deacetylase 3 (HDAC3) activity is regulated by interaction with protein serine/threonine phosphatase 4. Genes Dev, 2005. 19(7): p. 827-39.

101. Hervera, A., et al., PP4-dependent HDAC3 dephosphorylation discriminates between axonal regeneration and regenerative failure. EMBO J, 2019. 38(13): p. e101032.

102. Lyu, J., E.H. Jho, and W. Lu, Smek promotes histone deacetylation to suppress transcription of Wht target gene brachyury in pluripotent embryonic stem cells. Cell Res, 2011. 21(6): p. 911-21.

103. Huang, J. and L. Xue, Loss of flfl Triggers JNK-Dependent Cell Death in Drosophila. Biomed Res Int, 2015. 2015: p. 623573.

104. Parra, E., Activation of MAP kinase family members triggered by TPA or ionomycin occurs via the protein phosphatase 4 pathway in Jurkat leukemia T cells. Mol Med Rep, 2012. 5(3): p. 773-8.

105. Byun, H.J., et al., sMEK1 enhances gemcitabine anti-cancer activity through inhibition of phosphorylation of Akt/mTOR. Apoptosis, 2012. 17(10): p. 1095-103.

106. Kim, B.R., Y. Kwon, and S.B. Rho, BMI-1 interacts with sMEKI and inactivates sMEK1-induced apoptotic cell death. Oncol Rep, 2017. 37(1): p. 579-586.

107. Keogh, M.C., et al., A phosphatase complex that dephosphorylates gammaH2AX regulates DNA damage checkpoint recovery. Nature, 2006. 439(7075): p. 497-501.

108. Nakada, S., et al., PP4 is a gamma H2AX phosphatase required for recovery from the DNA damage checkpoint. EMBO Rep, 2008. 9(10): p. 1019-26.

109. O'Neill, B.M., et al., Pph3-Psy2 is a phosphatase complex required for Rad53 dephosphorylation and replication fork restart during recovery from DNA damage. Proc Natl Acad Sci U S A, 2007. 104(22): p. 9290-5.

110. Ma, J.L., et al., Activation of the checkpoint kinase Rad53 by the phosphatidyl inositol kinase-like kinase Mec1. J Biol Chem, 2006. 281(7): p. 3954-63. 
111. Sun, L.L., et al., Protein phosphatase Pph3 and its regulatory subunit Psy2 regulate Rad53 dephosphorylation and cell morphogenesis during recovery from DNA damage in Candida albicans. Eukaryot Cell, 2011. 10(11): p. 1565-73.

112. Uetz, P., et al., A comprehensive analysis of protein-protein interactions in Saccharomyces cerevisiae. Nature, 2000. 403(6770): p. 623-7.

113. Liu, J., et al., Protein phosphatase PP4 is involved in NHEJ-mediated repair of DNA double-strand breaks. Cell Cycle, 2012. 11(14): p. 2643-9.

114. Chowdhury, D., et al., A PP4-phosphatase complex dephosphorylates gamma-H2AX generated during DNA replication. Mol Cell, 2008. 31(1): p. 33-46.

115. Moore, J.K. and J.E. Haber, Cell cycle and genetic requirements of two pathways of nonhomologous end-joining repair of double-strand breaks in Saccharomyces cerevisiae. Mol Cell Biol, 1996. 16(5): p. 2164-73.

116. Omidi, K., et al., Phosphatase complex Pph3/Psy2 is involved in regulation of efficient non-homologous end-joining pathway in the yeast Saccharomyces cerevisiae. PLoS One, 2014. 9(1): p. e87248.

117. Park, J., J. Lee, and D.H. Lee, Identification of Protein Phosphatase 4 Inhibitory Protein That Plays an Indispensable Role in DNA Damage Response. Mol Cells, 2019. 42(7): p. 546-556.

118. Zhou, G., et al., Protein phosphatase 4 is involved in tumor necrosis factor-alphainduced activation of c-Jun N-terminal kinase. J Biol Chem, 2002. 277(8): p. 6391-8.

119. Mihindukulasuriya, K.A., et al., Protein phosphatase 4 interacts with and downregulates insulin receptor substrate 4 following tumor necrosis factor-alpha stimulation. J Biol Chem, 2004. 279(45): p. 46588-94.

120. Yeh, P.Y., et al., Suppression of MEK/ERK signaling pathway enhances cisplatininduced NF-kappaB activation by protein phosphatase 4-mediated NF-kappaB p65 Thr dephosphorylation. J Biol Chem, 2004. 279(25): p. 26143-8.

121. Chen, L., et al., Protein phosphatase 4 negatively regulates LPS cascade by inhibiting ubiquitination of TRAF6. FEBS Lett, 2008. 582(19): p. 2843-9.

122. Hadweh, P., et al., The PP4RI subunit of protein phosphatase PP4 targets TRAF2 and TRAF6 to mediate inhibition of NF-kappaB activation. Cell Signal, 2014. 26(12): $\mathrm{p}$. 2730-7.

123. Oler, A.J. and B.R. Cairns, PP4 dephosphorylates Maf1 to couple multiple stress conditions to RNA polymerase III repression. EMBO J, 2012. 31(6): p. 1440-52.

124. Su, C., et al., The Protein Phosphatase 4 and SMEK1 Complex Dephosphorylates HYL1 to Promote miRNA Biogenesis by Antagonizing the MAPK Cascade in Arabidopsis. Dev Cell, 2017. 41(5): p. 527-539 e5.

125. Wang, S., et al., The PROTEIN PHOSPHATASE4 Complex Promotes Transcription and Processing of Primary microRNAs in Arabidopsis. Plant Cell, 2019. 31(2): p. 486501.

126. Zhou, G., J.S. Boomer, and T.H. Tan, Protein phosphatase 4 is a positive regulator of hematopoietic progenitor kinase 1. J Biol Chem, 2004. 279(47): p. 49551-61.

127. Venkitaramani, D.V., et al., Mapping the Ca2+-dependent binding of an invertebrate homolog of protein phosphatase 4 regulatory subunit 2 to the small EF-hand protein, calsensin. Biochim Biophys Acta, 2006. 1763(3): p. 322-9.

128. $\quad \mathrm{Su}, \mathrm{Y} . \mathrm{W}$., et al., The serinelthreonine phosphatase PP4 is required for pro-B cell development through its promotion of immunoglobulin VDJ recombination. PLoS One, 2013. 8(7): p. e68804.

129. Chen, M.Y., et al., PP4 is essential for germinal center formation and class switch recombination in mice. PLoS One, 2014. 9(9): p. e107505.

130. Chen, M.Y., et al., PP4 deficiency leads to DNA replication stress that impairs immunoglobulin class switch efficiency. Cell Death Differ, 2019. 26(7): p. 1221-1234.

131. Shui, J.W., M.C. Hu, and T.H. Tan, Conditional knockout mice reveal an essential role of protein phosphatase 4 in thymocyte development and pre-T-cell receptor signaling. Mol Cell Biol, 2007. 27(1): p. 79-91. 
132. Liao, F.H., et al., T cell proliferation and adaptive immune responses are critically regulated by protein phosphatase 4. Cell Cycle, 2016. 15(8): p. 1073-83.

133. Liao, F.H., et al., Protein phosphatase 4 is an essential positive regulator for Treg development, function, and protective gut immunity. Cell Biosci, 2014. 4: p. 25.

134. Mourtada-Maarabouni, M. and G.T. Williams, Protein phosphatase 4 regulates apoptosis in leukemic and primary human T-cells. Leuk Res, 2009. 33(11): p. 1539-51.

135. Mourtada-Maarabouni, M., et al., Functional expression cloning reveals proapoptotic role for protein phosphatase 4. Cell Death Differ, 2003. 10(9): p. 1016-24.

136. Yoon, Y.S., et al., Suppressor of MEK null (SMEK)protein phosphatase 4 catalytic subunit (PP4C) is a key regulator of hepatic gluconeogenesis. PNAS, 2010. 107(41): p. 177704-17709.

137. Dou, L., et al., Mir-338-3p Mediates Tnf-A-Induced Hepatic Insulin Resistance by Targeting PP4r1 to Regulate PP4 Expression. Cell Physiol Biochem, 2017. 41(6): p. 2419-2431.

138. Wang, S., et al., miR3383p mediates gluconeogenesis via targeting of PP4RI in hepatocytes. Mol Med Rep, 2018. 18(4): p. 4129-4137.

139. Meng, X., et al., Protein phosphatase 4 promotes hepatic lipogenesis through dephosphorylating acetylCoA carboxylase 1 on serine 79. Mol Med Rep, 2014. 10(4): p. 1959-63.

140. Tomar, D., et al., Blockade of MCU-Mediated Ca(2+) Uptake Perturbs Lipid Metabolism via PP4-Dependent AMPK Dephosphorylation. Cell Rep, 2019. 26(13): p. 3709-3725 e7.

141. Glover, M., et al., The activity of the thiazide-sensitive $\mathrm{Na}(+)-\mathrm{Cl}(-)$ cotransporter is regulated by protein phosphatase PP4. Can J Physiol Pharmacol, 2010. 88(10): p. 98695.

142. Cundell, M.J., et al., A PP2A-B55 recognition signal controls substrate dephosphorylation kinetics during mitotic exit. J Cell Biol, 2016. 214(5): p. 539-54.

143. Hendrickx, A., et al., Docking motif-guided mapping of the interactome of protein phosphatase-1. Chem Biol, 2009. 16(4): p. 365-71.

144. Hertz, E.P.T., et al., A Conserved Motif Provides Binding Specificity to the PP2A-B56 Phosphatase. Mol Cell, 2016. 63(4): p. 686-695.

145. Roy, J., et al., A conserved docking site modulates substrate affinity for calcineurin, signaling output, and in vivo function. Mol Cell, 2007. 25(6): p. 889-901.

146. Wang, X., et al., Expanding the PP2A Interactome by Defining a B56-Specific SLiM. Structure, 2016. 24(12): p. 2174-2181.

147. Wu, C.G., et al., $P P 2 A-B^{\prime}$ holoenzyme substrate recognition, regulation and role in cytokinesis. Cell Discov, 2017. 3: p. 17027.

148. Tompa, P., et al., A million peptide motifs for the molecular biologist. Mol Cell, 2014. 55(2): p. 161-9.

149. Davey, N.E., M.S. Cyert, and A.M. Moses, Short linear motifs - ex nihilo evolution of protein regulation. Cell Commun Signal, 2015. 13: p. 43.

150. Kim, Y.M., et al., PNUTS, a protein phosphatase 1 (PP1) nuclear targeting subunit. Characterization of its $P P 1$ - and RNA-binding domains and regulation by phosphorylation. J Biol Chem, 2003. 278(16): p. 13819-28.

151. Egloff, M.P., et al., Structural basis for the recognition of regulatory subunits by the catalytic subunit of protein phosphatase 1. EMBO J, 1997. 16(8): p. 1876-87.

152. Terrak, M., et al., Structural basis of protein phosphatase 1 regulation. Nature, 2004. 429(6993): p. 780-4.

153. Gal, M., et al., The LXVP and PXIxIT NFAT motifs bind jointly to overlapping epitopes on calcineurin's catalytic domain distant to the regulatory domain. Structure, 2014. 22(7): p. 1016-27.

154. Peterson, F.C. and B.F. Volkman, Diversity of polyproline recognition by EVHI domains. Front Biosci (Landmark Ed), 2009. 14: p. 833-46.

155. Ueki, Y., et al., A Consensus Binding Motiffor the PP4 Protein Phosphatase. Mol Cell, 2019. 76(6): p. 953-964 e6. 
156. Karunakaran, R., et al., A family of promoter probe vectors incorporating autofluorescent and chromogenic reporter proteins for studying gene expression in Gram-negative bacteria. Microbiology (Reading), 2005. 151(Pt 10): p. 3249-3256.

157. Yashiroda, H., et al., The PY-motif of Bull protein is essential for growth of Saccharomyces cerevisiae under various stress conditions. Gene, 1998. 225(1-2): p. 3946.

158. Rothbauer, U., et al., Targeting and tracing antigens in live cells with fluorescent nanobodies. Nat Methods, 2006. 3: p. 887-889.

159. Schneider, I., Cell lines derived from late embryonic stages of Drosophila melanogaster. J Embryol Exp Morphol, 1972. 27(2): p. 353-65.

160. Lipinszki, Z., et al., Enhancing the Translational Capacity of E. coli by Resolving the Codon Bias. ACS Synth Biol, 2018. 7(11): p. 2656-2664.

161. Bownes, M., A photographic study of development in the living embryo of Drosophila melanogaster. J Embryol Exp Morphol, 1975. 33(3): p. 789-801.

162. Stapleton, M., et al., A Drosophila full-length cDNA resource. Genome Biol, 2002. 3(12): p. RESEARCH0080.

163. Drozdetskiy, A., et al., JPred4: a protein secondary structure prediction server. Nucleic Acids Res, 2015. 43(W1): p. W389-94.

164. Wolff, S., et al., SMK-1, an essential regulator of DAF-16-mediated longevity. Cell, 2006. 124(5): p. 1039-53.

165. Przewloka, M.R., et al., CENP-C is a structural platform for kinetochore assembly. Curr Biol, 2011. 21(5): p. 399-405.

166. Meszaros, B., G. Erdos, and Z. Dosztanyi, IUPred2A: context-dependent prediction of protein disorder as a function of redox state and protein binding. Nucleic Acids Res, 2018. 46(W1): p. W329-W337. 


\section{8. ÖSSZEFOGLALÓ}

A reverzibilis fehérje foszforiláció az eukarióta sejtekben az egyik leggyakoribb poszttranszlációs módosítás, mely számos fiziológiás folyamat szabályozásában nélkülözhetetlen. A fehérjék foszforilációs állapotát a fehérje kinázok és fehérje foszfatázok időben és térben precízen összehangolt müködése határozza meg. Míg a fehérje kinázok régóta az egyik legintenzívebben kutatott és legjobban ismert enzimcsalád, addig a fehérje foszfatázokról jóval kevesebbet tudunk.

A Ser/Thr foszfatázok PPP családjába tartozó PP4 foszfatáz leggyakrabban három alegységes holoenzim komplexként funkcionál. A holoenzim egy katalitikus (PP4c), egy szerkezeti (R2) és egy regulátor (R3, Drosophila-ban Falafel) alegységből áll, utóbbi felelős a szubsztrátum felismerésért és kötésért. A PP4 egy esszenciális foszfatáz, mely nélkülözhetetlen szerepet tölt be a sejtciklus, sejtosztódás, differenciálódás, apoptózis, DNS hibajavítás, több jelátviteli útvonal, valamint az immunrendszer és a metabolizmus szabályozásában. Mind a PP4 hiánya, mind túlzott aktivitása súlyos sejtosztódási rendellenességeket okozhat, mely különböző rákos megbetegedések kialakulásához vezethet.

A PP4 foszfatáz interakciós partnereinek azonosításához a Drosophila melanogaster PP4 Falafel alegységének konzervált EVH1 és Smk-1 doménjeit N-terminálisan GST fúziós fehérjével jelölt formában $E$. coli sejtekkel megtermeltettük és homogenitásig tisztítottuk, majd korai szinciciális embriókból származó lizátummal inkubáltuk együtt. Affinitás-tisztítást követő tömegspektrometriai analízissel 40 fehérjét azonosítottunk, mint a PP4 potenciális új interakciós partnerei.

Az EVH1 és Smk-1 doménekkel valódi fizikai kölcsönhatást kialakító fehérjék azonosításához in vitro kötési kísérleteket végeztünk. Ehhez próba fehérjeként baktérium sejtekből homogenitásig kitisztított és affinitás gyöngyökön immobilizált GST-EVH1-et és GST-Smk-1-et használtunk. A vizsgálni kívánt fehérjéket kapcsolt in vitro transzkripciós/transzlációs rendszerrel termeltettük és az autoradiográfiás detekció érdekében ${ }^{35} \mathrm{~S}$-metioninnal jelöltük. Ezen módszerrel sikerült hét fehérjét (Prp16, Psc, Incenp, Sowah, Stwl, Centrobin és CG8478) azonosítanunk, mint új EVH1 kölcsönható partner és nyolc olyan fehérjét (Licorne, Nipsnap, RfC4, Zwilch, ZW10, Spindle A, $\gamma$ Tub23C és Grip75), melyek a Falafel Smk-1 doménjével lépnek specifikus kölcsönhatásba. 
Kutatásunk egyik fô célja a PP4 foszfatáz szubsztrátum-felismerési módjainak vizsgálata és egy lehetséges konzervált szubsztrátum-felismerési motívum azonosítása volt. Ehhez első lépésként az egyes domének és az újonnan meghatározott interakciós fehérjék közötti lehető legrövidebb kölcsönhatási felületet határoztuk meg. A fehérjékből rövidebb, egymással átfedő szakaszokat hoztunk létre és a korábban is alkalmazott in vitro kötési kísérletekkel azonosítottuk azon részeit, melyek szükségesek az EVH1 vagy Smk-1 doménhez való kötődéshez.

A szakirodalomból két, kísérletesen is igazolt Drosophila fehérjét ismerünk (CENP-C és Miranda), amelyet a Falafel EVH1 doménje köt meg. Mindkét fehérjében található egy rövid motívum (FxxP), mely az általunk azonosított interakciós fehérjékben több helyen is megtalálható (kivéve CG8478), ezért nagy a valószínüsége, hogy ez a peptid a PP4 foszfatáz konzervált felismerési motívuma. 2019 végén megjelent egy közlemény, melyben Ueki és munkatársai azonosították a humán PP4 szubsztrátum felismerési motívumát. Megfigyeléseik egybevágnak a mi eredményeinkkel Drosophila-ban. Az FxxP motívum mellett egy MxPP motívumot is leírtak, ezért további vizsgálatainkat mi is kiterjesztettük erre a motívumra. A legtöbb fehérjénk esetében mindkét motívum több helyen is előfordult az aminosav szekvenciában, ezért helyspecifikus mutagenezis segítségével a motívumok első és negyedik pozíciójában lévő F és $\mathrm{P}$, illetve $\mathrm{M}$ és $\mathrm{P}$ aminosavakat alaninokra cseréltük. Minden vizsgált fehérje esetében találtunk egy kiemelt helyen lévő FxxP vagy MxPP motívumot, melynek mutációja az EVH1-el kialakított kölcsönhatás nagymértékű gyengüléséhez vagy teljes eltünéséhez vezet.

Bebizonyítottuk, hogy a Falafel EVH1 doménjének 70. pozíciójában lévő leucinnak kiemelten fontos szerepe van a kölcsönható fehérjék megkötésében. Ezen aminosav alaninra történő cseréje esetén a vizsgált Drosophila fehérjékkel szemben az EVH1 domén teljesen elveszítette a kötőképességét. Kimutattuk azt is, hogy nem csak az EVH1-en keresztüli szubsztrátum kötés, hanem ezen leucin nélkülözhetetlen szerepe is erősen konzervált a fajok között. Míg a humán SMEK1 EVH1 doménje képes volt megkötni a vizsgált Drosophila fehérjéket, addig a konzervált leucin alaninra történő cseréje itt is a kötődés teljes megszünéséhez vezetett.

Eredményeink azt mutatták, hogy az Smk-1 doménen keresztüli interakciós partnerek felismerése és megkötése az EVH1 doméntől független módon történik, az Smk-1 doménnel kölcsönhatásba lépő fehérjék egyike sem kötődik az EVH1 doménhez. Az Smk-1 interakciós fehérjék közül csupán a ZW10 hordoz két FxxP motívumot, 
azonban ezek mutációja in vivo ko-immunprecipitációs kísérleteink alapján nincs hatással a kölcsönhatásra. Annak meghatározása, hogy az Smk-1-en keresztül hogyan valósul meg az interakciós fehérjék kötődése, még további vizsgálatokat igényel.

Kollaborációs partnereinkkel közösen kimutattuk, hogy a PP4-nek fontos szerepe van a Barrier-to-autointegration factor (BAF) foszforegulációjában a sejtosztódás során. A PP4 a CENP-C-vel és a BAF-al egy egymástól függő, pozitív visszacsatolási hálózatot alkot a centroméránál, bármely komponens kiütése közvetett vagy közvetlen módon hatással van a másik két fehérje funkciójára és lokalizációjára. Kötési kísérleteink alapján a BAF nem kötődik sem a Flfl EVH1, sem az Smk-1 doménjéhez, azonban a PP4/Flfl komplex bizonyítottan defoszforilálja. Ebből az következik, hogy a PP4 szubsztrátum felismerése nem csak közvetlen módon, a konzervált doménjein keresztül valósulhat meg, hanem egy harmadik, közvetett módon is, egy közvetítő fehérjén keresztül, amely a BAF esetében a CENP-C. 


\section{SUMMARY}

Reversible protein phosphorylation is one of the most common post-translational modifications in eukaryotic cells and is essential in the regulation of many physiological processes. The phosphorylation state of the proteins is determined by the precisely coordinated action of protein kinases and protein phosphatases. While protein kinases have long been one of the best-known families of enzymes, the knowledge available about protein phosphatases is limited.

PP4 phosphatase, a member of the PPP family of Ser/Thr phosphatases, most commonly functions as a three-subunit holoenzyme. The holoenzyme consists of a catalytic (PP4c), a structural (R2), and a regulatory (R3, Falafel in Drosophila) subunit, the latter being responsible for substrate recognition and binding. PP4 is an essential phosphatase that plays a central role in the regulation of the cell cycle, cell division, differentiation, apoptosis, DNA repair, multiple signalling pathways, the immune system and metabolism. Both PP4 deficiency and excessive activity can cause severe cell division disorders, which can lead to the development of various cancers.

To identify the novel interactional partners of the PP4 phosphatase, we purified N-terminally GST-fused EVH1 and Smk-1 form E. coli cells and incubated it with lysates of early syncytial Drosophila embryos. Affinity purification followed by mass spectrometric analysis identified 40 proteins as potential new interaction partners of PP4.

We performed in vitro binding experiments to identify the proteins which are real physical interaction partners of the EVH1 and Smk-1 domains. GST-EVH1 and GST-Smk-1 purified from bacterial cells to homogeneity and immobilized on affinity beads were used as bait proteins. Our prey proteins were produced by a coupled in vitro transcription/translation system and labelled with ${ }^{35} \mathrm{~S}$-methionine for autoradiographic detection. Using this method, we were able to identify seven proteins (Prp16, Psc, Incenp, Sowah, Stwl, Centrobin, and CG8478) as new EVH1 interacting partners and eight proteins (Licorne, Nipsnap, RfC4, Zwilch, ZW10, Spindle A, $\gamma$ Tub23C, and Grip75), which specifically interact with the Smk-1 domain of Falafel.

One of the main objectives of our research was to investigate the modes of the substrate recognition of $\mathrm{PP} 4$ phosphatase and to identify a possible conserved substrate recognition motif. As a first step, we determined the shortest possible interaction surface between each domain and the newly defined interaction proteins. Shorter, overlapping 
sections of the proteins were generated, and the fragment of each protein required for binding to the EVH1 or Smk-1 domain was identified by in vitro binding experiments.

Two experimentally validated Drosophila proteins (CENP-C and Miranda) bound by the EVH1 domain of Falafel are known from the literature. Both proteins contain a short motif (FxxP), which is also present at multiple sites in the interaction proteins we identified (except CG8478), suggesting this motif mediates recognition by PP4. A paper was published in late 2019 in which Ueki et al. identified the substrate recognition motif of the human PP4 phosphatase. Their observations are consistent with our findings in Drosophila. In addition to the FxxP motif, an MxPP motif was also described by them, so we extended our further studies to this motif as well. For most of our proteins, both motifs occurred at multiple sites in the amino acid sequence, so we replaced the $\mathrm{F}$ and $\mathrm{P}$ or $\mathrm{M}$ and $\mathrm{P}$ amino acids at the first and fourth positions of the motifs with alanines by site-directed mutagenesis. Based on our results, each protein has a prominent FxxP or MxPP motif, the mutation of which leads to a large attenuation or complete disappearance of the EVH1 interaction.

We demonstrated that leucine at 70th position of the EVH1 domain of Falafel has a prominent role in the binding of interacting proteins. Upon replacement of this amino acid with an alanine, the EVH1 domain completely lost its binding capacity to the tested Drosophila proteins. We have also shown that not only substrate binding through EVH1, but also the essential role of this leucine is highly conserved among species. While the EVH1 domain of human SMEK1 was able to bind the tested Drosophila proteins, replacement of conserved leucine with alanine again led to complete loss of binding.

Based on our results, the recognition and binding of interaction partners through the Smk-1 domain is independent of the EVH1 domain, and none of the proteins interacting with Smk-1 bind to the EVH1 domain. Of the Smk-1 interaction proteins, only ZW10 carries two FxxP motifs, however, their mutation has no effect on the interaction based on our in vivo co-immunoprecipitation experiments. Determining how the binding of interaction proteins happens through Smk-1 requires further investigation.

In the framework of an international cooperation, we have shown that PP4 plays an important role in the phosphoregulation of BAF during cell division. PP4 together with CENP-C and BAF form an interdependent, positive feedback network at the centromere. Knockout of any component directly or indirectly affects the function and localization of the other two proteins. Based on our binding experiments, BAF does not bind to either the Flfl EVH1 or Smk-1 domains, however, the PP4/Flfl complex has been shown to 
dephosphorylate it. It follows that recognition of the PP4 substrates can be achieved not only directly, through its conserved domains, but also, in a third, indirect way, through a HUB protein, which in the case of BAF is CENP-C. 


\section{MELLÉKLET}
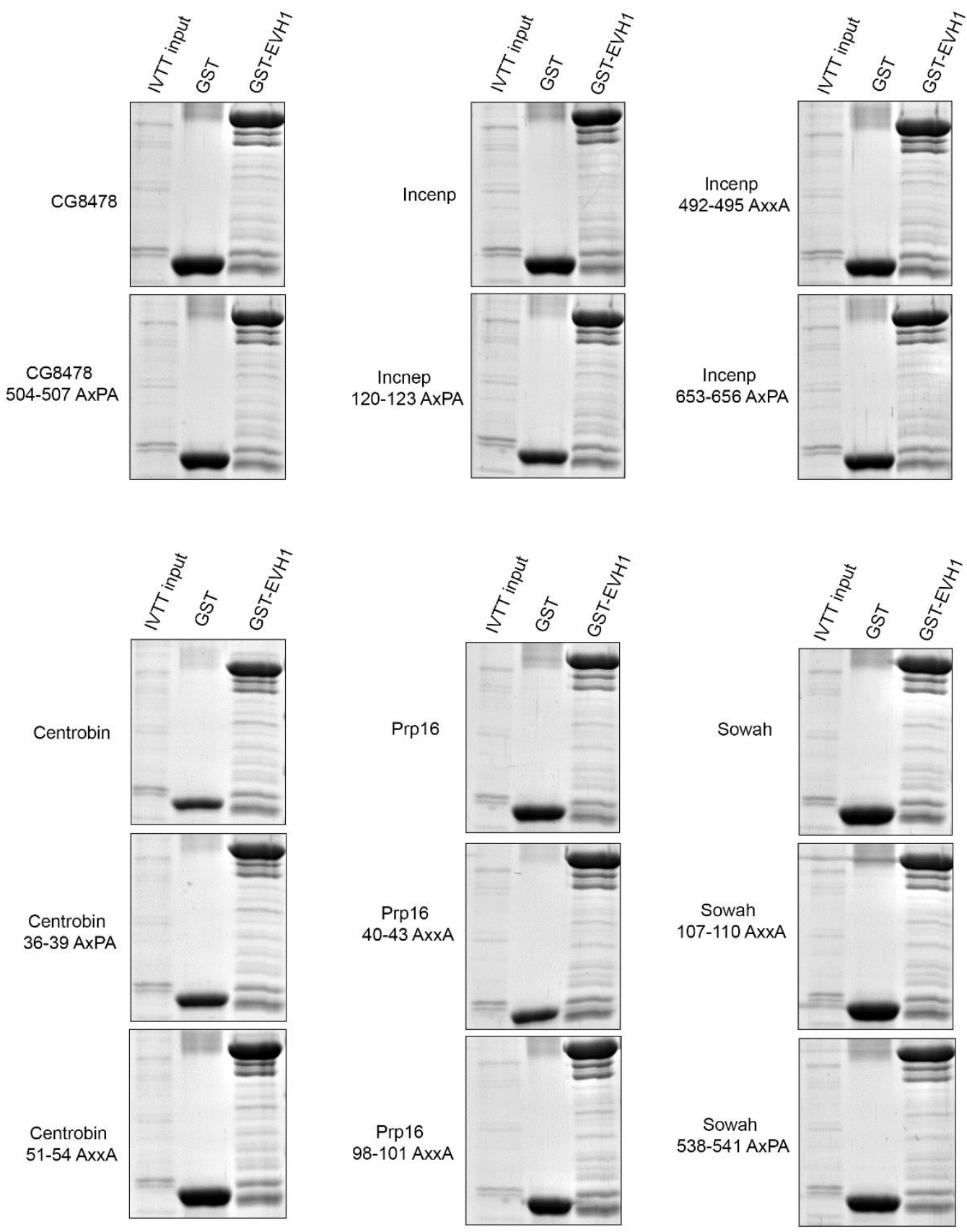

M1 ábra. FxxP és MxPP motívumok mutagenezisének Coomassie festett géljei I. 

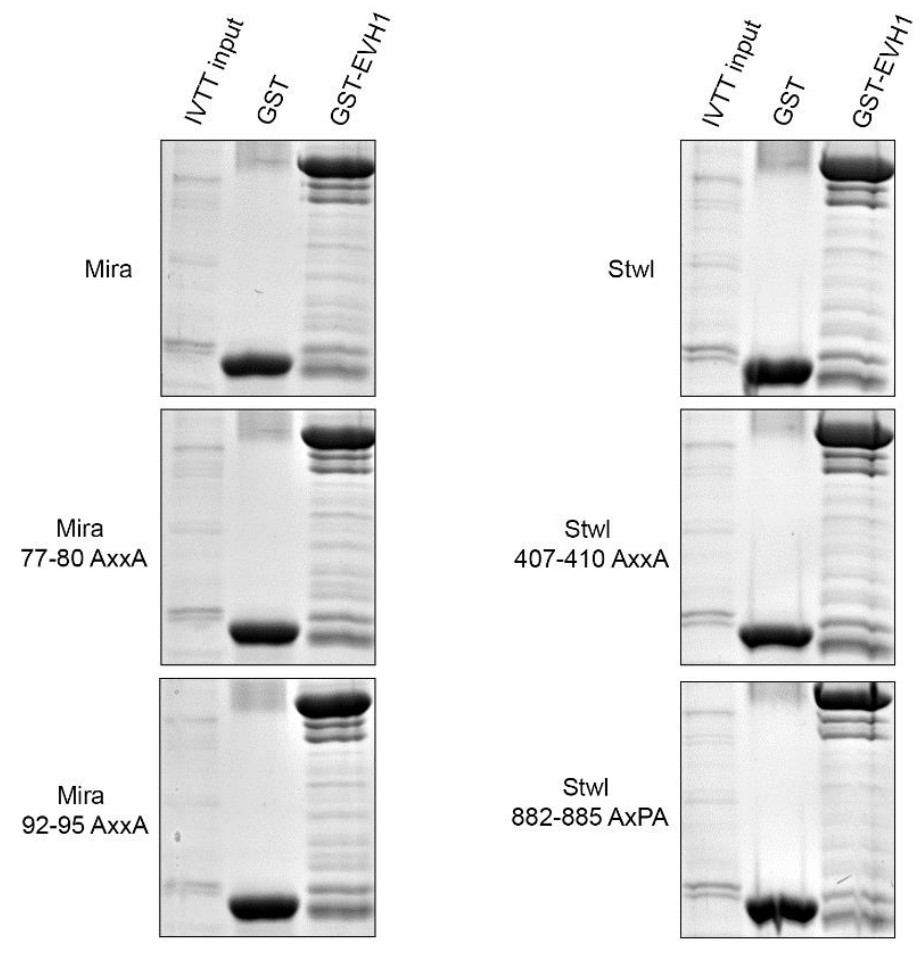

M2 ábra. FxxP és MxPP motívumok mutagenezisének Coomassie festett géljei II. 
A

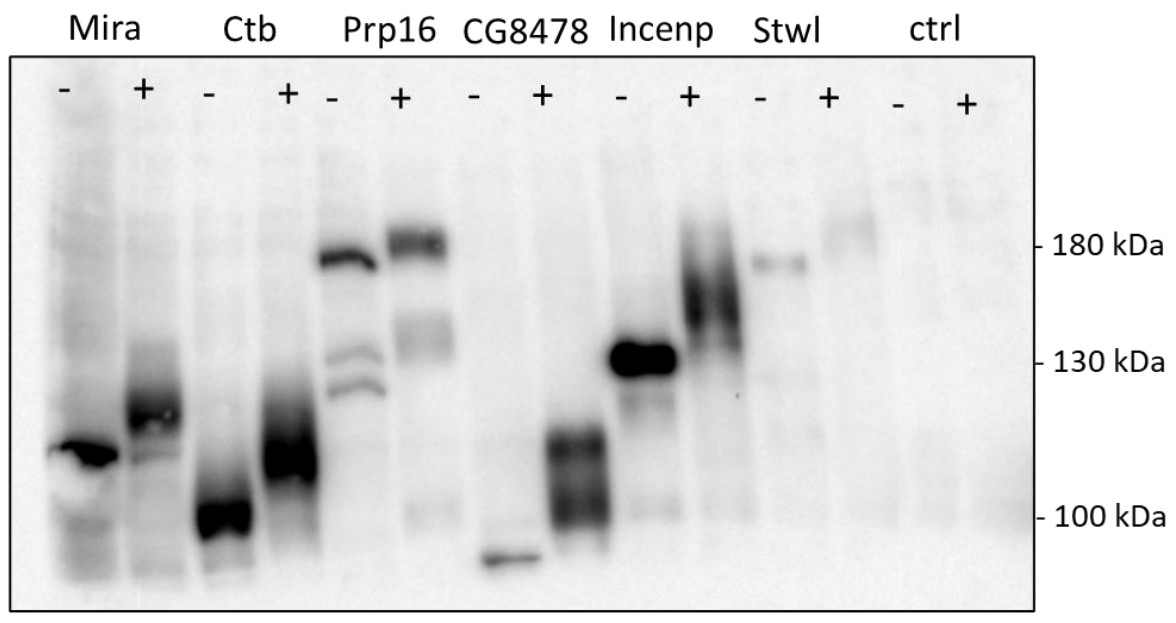

B

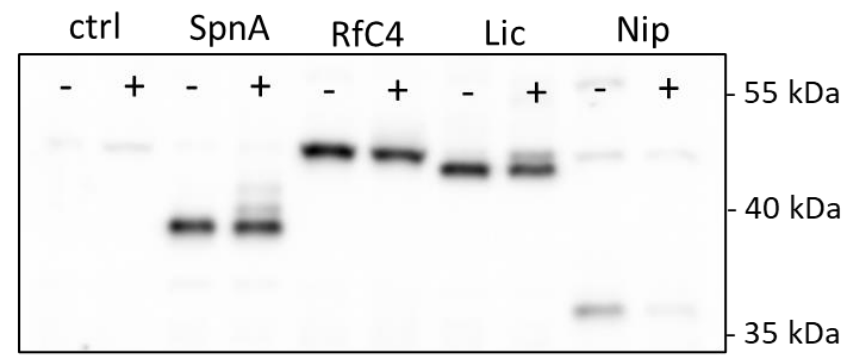

C

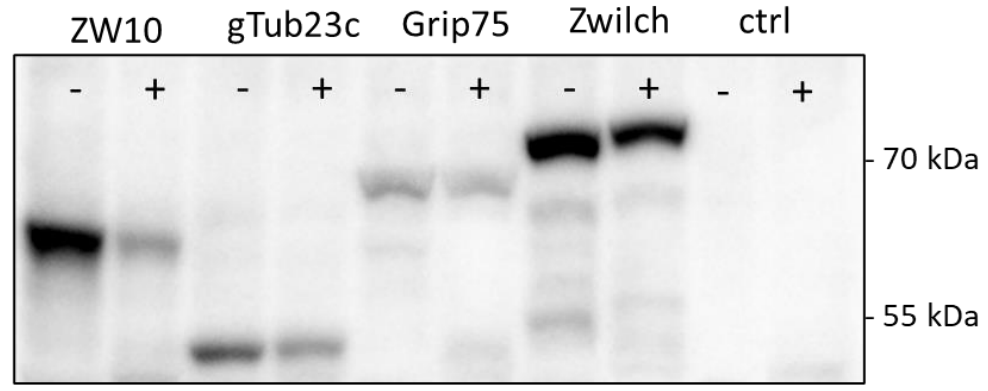

M3 ábra. Az okadainsav kezelés hatása az EVH1 (A) és az Smk-1 (B, C) interakciós partnerek foszforiláltsági állapotára. Az okadainsavval nem kezelt (-) és kezelt (+) sejtekből származó mintákat Western-blot segítségével vizsgáltuk. Az okadainsav kezelés hatására bekövetkezett foszforiláltsági állapot változásra az egyes fehérjék méret változásából következtethetünk. 